\title{
IGUALDADE RACIAL
}

\section{APRESENTAÇÃO}

Este capítulo tem o objetivo de identificar questôes importantes para a política de igualdade racial e para a situação social da população negra entre 2013 e 2014. A tarefa de seleção dessas questóes não é simples, pois, por um lado, a política em questão tem apresentado diversos progressos, aprofundado sua abrangência e conquistado mais repercussão social. Por outro lado, o racismo e a intolerância também têm tomado maior vulto nos últimos tempos. As explicaçóes para essa situação dividem-se em argumentos não excludentes: maior visibilidade e o crescimento do racismo.

Para a primeira linha, o racismo, que sempre esteve presente de modo determinante, especialmente na pele de quem é vítima, toma outras proporçóes à medida que aumenta a visibilidade social ao problema. Esta visibilidade pode ser atribuída ao maior alcance das redes sociais e acesso à informação, de forma geral, que permite difundir com maior rapidez esses fatos, além de viabilizar a públicos menos influentes a possibilidade de produção e reprodução das notícias, sob suas perspectivas particulares. Há também maior permeabilidade do tema na pauta da grande mídia, em um processo de crescente debate público sobre racismo estabelecido, especialmente, com o tema das cotas nas universidades. E há um genuíno empoderamento da população, que tem cada vez mais se reconhecido como negra e cada vez menos tolerado ser subjugada por seu pertencimento racial.

A segunda linha explicativa constata que o crescimento do racismo ocorre ao passo que se testemunha um fluxo de ascensão social e econômica de negros que conduz a mudanças no nível e na natureza de suas demandas à medida que passam a frequentar e ocupar, em maior número, espaços que não eram (ou não são) socialmente identificados como seus. Estes espaços não são apenas presenciais, como aqueles intensificados pelas cotas em universidades ou concursos públicos ou pelo maior acesso ao consumo de parte deste segmento, mas são também espaços simbólicos, de formação de políticas públicas, de preferências na alocação de recursos, de construçấo de imaginários. O racismo emerge como arma de confrontação.

Diante deste cenário, o racismo e suas recentes manifestaçôes são abordados na seção de Fatos Relevantes a partir dessas duas perspectivas. A primeira parte da seção 
oferece uma análise sobre a questáo racial, tomando o contexto dos grandes eventos que o país abrigou recentemente como pano de fundo. Para tanto, o imaginário e a ação em relação ao negro são analisados dentro do campo, na construção do mito do país do futebol, e fora de campo, nas dinâmicas de ordenamento territorial e gerenciamento de conflitos. O reflexo do racismo na dimensão religiosa é tema da segunda parte desta seção 2 .

Por fim, a seção "Fatos relevantes" apresenta dois elementos de progresso da política, que também explicitam suas fragilidades. A inclusão do quesito sobre cor ou raça dos candidatos a cargos públicos possibilita novo patamar no exame sobre eleiçôes, desde a formação de candidaturas até as preferências eleitorais. No entanto, também desvela a baixa chance eleitoral de candidatos negros, ainda que sua participação no processo eleitoral náo seja diminuta. Finalmente, a seçáo 2 termina com o tema da III Conferência Nacional de Políticas de Promoção da Igualdade Racial, culminância de um período de 10 anos de criaçáo da Secretaria de Políticas de Promoção da Igualdade Racial, mas que também ilustra, nesta trajetória, limites para efetivação da política.

A seção 3, "Acompanhamento da política e dos programas", trata de açôes afirmativas para a população negra e, de forma mais específica, da sua modalidade de cotas, tanto no ensino superior como na administração pública. Para ambos os espaços de aplicação das medidas, o período 2013-2014 foi decisivo. Ao final, a execução orçamentária da Seppir e o debate sobre o orçamento da política de igualdade racial e seu monitoramento, em sentido amplo, sáo retomados.

Por fim, em face desse breve percurso sobre a política e o cenário da questão racial, apresentam-se alguns desafios a serem enfrentados pelos novos governos.

\section{FATOS RELEVANTES}

\subsection{Mito fundador, racismo e futebol na terra da copa das copas}

Desde os primeiros dias de invasão desses costados por sotaques portugueses começou-se a esboçar os contornos de uma terra guardiã de futuro grandioso, de natureza e recursos fartos, dádiva divina, livre de todas as intempéries e catástrofes que abundam noutros continentes. País do futuro, guardiāo das bênçãos divinas; um povo acolhedor que celebra a ordem e a paz, que abraça os estrangeiros e lhes oferece todas as oportunidades; uma democracia racial concretizada na mestiçagem; uma miscigenação que nos legou a ginga e a magia alegre do futebol moleque, a malandragem e o improviso; um país que repudia a vagabundagem, sustentáculo da violência, e cujos contrastes regionais são facilmente traduzidos em diversidade cultural e econômica (Chauí, 2000). Esta amálgama de elementos reforça a ideia suposta de identidade e pertencimento a uma nação. 
Nessas narrativas clássicas, trazidas de tempos em tempos por oradores argutos, toma forma um povo, uma unidade constituída da miscigenação de três raças: os índios, os negros e os portugueses, acompanhados séculos depois por uma leva de imigrantes europeus que, trazidos com o propósito de embranquecer a populaçáo, foram beneficiados pela mais ampla e eficiente política de cotas que este paraíso terrestre já ofereceu. A ideia da mestiçagem enquanto conteúdo essencial daquilo que compreendemos sob o termo "naçáo", teria, segundo esses mesmos narradores, esmaecido preconceitos de cor e etnia, dando origem à fina flor da elegância ordeira e pacífica que estampa a bandeira nacional e o comportamento dos indivíduos inscritos numa suposta formação social homogênea. As divisóes sociais e políticas internas neste modelo de representação só poderiam ser explicadas a partir da eleiçấo de amigos e inimigos internos, consubstanciada em nossa quadra histórica na máxima "Brasil, ame-o ou deixe-o". Em suma, este é o pano de fundo de nosso mito fundador, solução imaginária para conflitos e tensôes que não encontram resolução no plano do real concretamente vivido (Chauí, 2000).

Todos os dias este mito é revisitado, reconstruído e confrontado por sucessivas geraçóes de negras e negros socializados para não tolerar. Prisóes ilegais, casos de tortura, linchamentos, ofensas racistas nos gramados e nas arquibancadas saíram das páginas policiais para ocupar as seçôes principais de grandes jornais e programas de televisão. As intempéries reiteradas de um período turbulento têm colocado em questão este mito, sua roupagem e significação. Afinal de contas, de que forma podemos compreender o mito da democracia racial à luz das configuraçóes atualmente assumidas por um racismo cada vez menos isento de sua pretensa cordialidade clássica?

A conjuntura atual vem revelando práticas racistas fora do represamento político que o mito da democracia racial tendeu a alicerçar ao longo da história. Aparentemente, múltiplos fatores vêm contribuindo para isto, dentre os quais alguns merecem destaque: aumento da visibilidade da reação de mulheres e homens negros aos racismos cotidianamente sofridos; reação conservadora à ascensão, ainda que marginal, de fraçóes do povo negro, sobretudo em face da sua presença em espaços antes exclusivos dos brancos.

Esta análise de conjuntura pretende se debruçar sobre diferentes fatos ocorridos entre junho de 2013 e agosto de 2014, tendo por eixo central a pauta racial e suas diferentes formas de expressão na arena pública. Num primeiro momento, analisaremos os casos de racismo oriundos dos gramados e arquibancadas atualizando o debate sobre as relaçóes históricas entre o futebol e a raça, sobretudo em face da realização de uma Copa do Mundo no Brasil; num segundo momento, analisaremos o entrelaçamento da questáo racial e a militarização da questão urbana, problema vivido cotidianamente pela população negra, que já vinha sendo apontado por 
inúmeras organizações e que ganhou eco nas manifestaçóes de junho de 2013. Estes dois eixos de análise da conjuntura atual, embora estejam aparentemente separados, possuem um elemento em comum: a manipulação do discurso da violência como eixo legitimador de um conjunto de políticas e medidas concretas de controle social que terá no corpo negro o seu cliente preferencial.

\subsubsection{A Copa do Mundo, o racismo nos estádios e o negro escondido nas flâmulas da nação}

No dia 28 de agosto de 2014, Mario Lucio Duarte Costa ${ }^{1}$ entra em campo para jogar apenas mais uma dentre as inúmeras partidas que houvera disputado ao longo da carreira. Este dia, porém, tornou-se o emblema de um período, o símbolo dos enfrentamentos cotidianos de uma geração de negras e negros que veem o racismo emergir dos alicerces de uma sociedade pretensamente cordial. Ironicamente é o futebol, lugar em que os negros teriam sido supostamente integrados, um dos palcos desta emergência. Aranha fora chamado de macaco por parte da torcida do Grêmio. No dia 18 de setembro, após denúncia que culminou com a eliminação do time dos ofensores, Aranha foi vaiado durante os noventa minutos de partida. Uma vaia diferente daquelas que todos os jogadores estáo acostumados a enfrentar. Repentinamente aquela arquibancada, vestígio de um coliseu romano, invertia os polos da relação, transformando ofendido em ofensor. Um dia antes fora hostilizado pelo técnico do time adversário, que lhe atribuiu indiretamente a velha pecha da armaçâo e da malandragem; após o jogo fora ironizado pela repórter de uma rede de televisão, que sugeria em suas perguntas a imputação do exagero e da vitimização. Em suma, Aranha viveu nestes dias, por diferentes formas, aquilo que Barbosa, Juvenal e Bigode, ${ }^{2}$ jogadores negros vilanizados pela derrota da seleçấo brasileira na Copa de 1950, tiveram de suportar durante toda a sua vida: o peso enorme do racismo numa sociedade fundada sobre os escombros da escravidão.

Até então, o racismo nos estádios de futebol era tratado como uma espécie de problema estrangeiro. Enquanto a Europa viu se multiplicarem torcidas organizadas ligadas a grandes clubes com nítida conotação fascista e xenófoba - as ultras -, o futebol brasileiro parecia já ter superado fenômenos desse matiz. Mesmo quando ocorria nos gramados locais, ofensas racistas pareciam recair sobre os brasileiros apenas como vítimas, tal como ocorria nas incursóes nos campos europeus ou

1. Aranha já havia vivido um caso típico de racismo poucos anos atrás. Em 2005, quando levava uma criança branca para o ambulatório de um hospital em Campinas, fora abordado por policiais, detido e algemado, sob a suspeita de tê-la sequestrado. A este respeito ver Resende (2014).

2. No dia 17 de julho de 1950, uma manchete do Jornal dos Sports, de propriedade de Mario Filho, estampava em matéria de capa o título Bofetada de Obdúlio Varela em Bigode deu o título mundial ao Uruguai. A suposta bofetada de Obdulio, jamais comprovada, fora utilizada como o clímax de uma narrativa que compunha o famoso Maracanazzo (Soares, 1999). Os ecos de 1950 ganharam manchetes e crônicas de um país que se reencontrava com os "traumas" de uma Copa perdida pela síndrome de vira-latas e pelas fragilidades da raça, representadas nas figuras de Bigode, Juvenal e Barbosa, escolhidos como vilões numa espécie de roteiro folhetinesco reproduzido de forma rotineira pela imprensa esportiva (Costa, [s.d.]). 
sul-americanos. Esta percepção socialmente disseminada supunha que o futebol brasileiro houvera se transformado, de fato, em lugar de inversão social, de suspensão da ordem cotidiana. Ideia que comparece nos discursos rotineiros que defendem a prática esportiva como paradigma civilizatório, solução para conflitos entre povos, naçóes, classes e raças, solução para a criminalidade juvenil, oportunidade de trabalho e mobilidade social para a juventude negra empobrecida, entre outros mitos (Vieira, 2003). A explicitação destes casos 3 às vésperas da Copa do Mundo, sediada pelo maior país negro fora da África, colocou em xeque estas percepções.

A história do futebol ${ }^{4}$ está intimamente relacionada com a história do negro no Brasil e a sua inserção é congruente a uma sociedade de matriz escravocrata. A narrativa consolidada em obras como a de Mario Filho (2010) costuma representá-la como uma espécie de história linear e mítica dividida em atos: o primeiro ato é marcado pelo surgimento do esporte no país, de matiz explicitamente elitista. Aqui o negro tivera o acesso bloqueado tanto aos campos quanto às arquibancadas: seguiu-se um período de popularizaçáa ${ }^{5}$ do esporte entre 1910 e 1920 e a crise institucional que isso gerou, sobretudo quanto à contratação de jogadores negros por alguns times e o conflito estabelecido entre defensores do amadorismo e da profissionalização; a partir de 1933, a profissionalização teria construído as bases para o incremento da inserçấo dos jogadores negros, que tinham o futebol não apenas como esporte, mas como profissão. Neste período os negros foram integrados aos clubes e à seleção brasileira; mais tarde a derrota na copa de 1950 teria reacendido as chagas do racismo, com a eleiçáo de três jogadores negros como responsáveis

3. Na Espanha torcedores jogaram uma banana para Daniel Alves; no Peru, Paulo César Tinga foi recebido com os sons de um macaco durante uma partida; no interior de São Paulo, a vítima foi Arouca, durante partida contra o Mogi Mirim; no interior de Minas, Assis, lateral do Uberlândia, foi vítima de racismo praticado por um membro da torcida do Mamoré; no Rio Grande do Sul, o juiz Márcio Chagas foi chamado de macaco safado e encontrou seu carro repleto de bananas ao fim do jogo, tendo decidido se aposentar após o ocorrido.

4. 0 futebol, quando surgiu, fora uma resposta às demandas de seu tempo. Normatizado através de leis, regras e estatutos, cumpria com os desígnios para os quais diversos esportes foram também criados: manutenção da ordem estabelecida mediante disciplinamento do corpo e a criação de hierarquias e instâncias de representação (capitão do time, presidente do clube, federação etc.). Sistemas de jogo eram definidos tomando por inspiração a conjuntura política e militar e suas estratégias. Sua transposição para outros países resultou de uma hegemonia geopolítica britânica que exportava práticas sociais e culturais utilizadas por elites locais como peça de um projeto civilizatório que unia pessoas da mesma classe social e racial. Num país fundado sob um regime escravocrata, o futebol expressaria, por seu turno as ambivalências e as contradições do racismo socialmente produzido por indivíduos, grupos e instituições e resistências a ele produzidas. Assim, embora em sua origem este esporte esteja intimamente ligado à tradição aristocrática inglesa, suas significações sociais e representações serão, ao longo do tempo, resultado do processo de apropriação efetuado por setores sociais diversos, principais responsáveis pela sua transformaç̧ão num fenômeno de massas (Franco Junior, 2007) 5. A popularização do futebol tem forte relação com o crescimento das cidades e a industrialização, que conduziu grandes levas de trabalhadores a "migrarem" do campo para a cidade. Subtraídas de seu local de origem, muitos trabalhadores recorriam ao futebol como forma de construir identidade num novo lugar de vida e trabalho. A adesão de negros, brancos pobres e imigrantes europeus a esta prática esportiva garantiu a difusão acelerada de jogadores e espectadores. Acomodaç̃es foram construídas e o público ampliou-se a tal ponto que os clubes passaram a apostar na cobrança de ingressos como forma de angariar receita (Santos, 2014). A consolidação do processo de profissionalização na década de 30 provocou ampliação dos custos de manutenção dos clubes, obrigando-os a buscarem novos torcedores e associados capazes de pagar pelos ingressos. Iniciou-se assim uma demanda por construção de estádios e ampliação de praças desportivas que tiveram no Estado seu maior financiador (Santos, 2014), 
pela derrota; por fim, a redenção do negro, depositada simbolicamente nas figuras de Garrincha e, sobretudo, Pelé (Filho, 2010).

A narrativa clássica do futebol ainda em voga na atualidade reproduz as teses que sustentavam uma espécie de atenuação das tensões e conflitos raciais através de sua prática. Desde o período autoritário varguista o futebol foi, junto com o carnaval, alçado à condiçáo de principal produto popular, instrumento através do qual fora forjado um forte sentimento de identidade nacional e apelo nacionalista. O Brasil se entendia e descrevia desde então a partir do futebol, descobria nele sua brasilidade, expressa num jeito próprio de ser e jogar (Franco Junior, 2007). E aqui o elemento racial aparece como elemento revelador da brasilidade: o futebol arte era resultado de uma subjetividade negra malandra, cuja flexibilidade e capacidade de improviso diante das adversidades desmontavam esquemas rígidos de ataque e defesa; a capoeira projetava sobre o ludopédio o uso desinibido do corpo, misturando dança, luta e diversão (Franco Junior, 2007).

Estudos elaborados na Europa desde os anos 70 apontam a forte correlação existente entre o perfil racial dos jogadores e padróes subjetivos requeridos para a ocupação de diferentes posiçóes. Enquanto brancos são usualmente associados a posiçôes de liderança, inteligência e controle emocional, os negros são associados à força, velocidade, emotividade, instinto, rapidez (Vieira, 2003). Esta associação reproduz as clivagens racistas que apareceram nos estádios associando a negritude ao corpo animal. O corpo é basicamente o território do negro, enquanto os brancos são associados à razáo e à tática. Em uma leitura aparentemente poética do futebol brasileiro, Gilberto Freyre (1938) apontava para a superioridade da forma brasileira de jogo a partir da reproduçáo destes padróes subjetivos: enquanto os europeus praticavam um futebol apolíneo, cerebral, calculado, ordenado, matemático, o mulatismo brasileiro construiu as bases de um futebol dionisíaco, criativo, inventivo, impulsivo.

Assim, se no século XIX a presença do negro na formação da sociedade brasileira era vista como algo negativo, a partir dos anos 30 esta relaçáo se inverte, sintetizada nos defensores da miscigenação positiva. Este aparente elogio da contribuição do negro era expressáo da ideia de que o futebol era um espaço onde a democracia racial ganhava expressão; a transformação da Copa de 1950 num rito de morte coletiva e as fragilidades da raça como explicaçáo da derrota eram a antessala da produção futura de heróis negros, que compareciam a esse discurso como elemento probatório de um processo histórico redentor; por fim, a miscigenação, ao fim e ao cabo, era o eixo central de sustentação dessa sociabilidade harmoniosa que permitiu a integração plena do negro e a sua vitória mítica. Pelé surgia aqui como figura que simboliza a superaçáo do racismo e o apagamento de sua identificação racial via ascensão econômica (Basthi, 2014). Com isso, a narrativa futebolística, 
ao pretender contar a história do negro nestes termos, reproduziu grandes mitos produtores e reprodutores de racismo que perduram até os dias atuais.

\section{As arenas e o controle social das torcidas como motor do embranquecimento das arquibancadas}

Enquanto metáfora social, redenção de um povo, realização de um projeto de nação, o futebol era também condicionado pelas relaçôes que o poder político econômico estabelecera com sua prática e disseminação. Em tempos ditatoriais, a propaganda a serviço do futebol foi extremamente útil à defesa de bandeiras nacionalistas. Tanto na ditadura militar quanto na era Vargas foi utilizado como bandeira de unificação nacional e ilustração da realização de um país desenvolvido. No Estado Novo foi conduzido à condição de símbolo de brasilidade e integração nacional. O Estado passava entáo a construir superestádios, feito repetido pela ditadura militar nos anos 70 .

Esse repertório que relaciona futebol e política tem sido, embora antigo, constantemente renovado. Os estádios foram, antes como agora, utilizados como ícones de uma nação moderna, demonstraçáo da capacidade de realização de um evento mundial, eixos estruturantes da identidade nacional. Porém, a despeito das similitudes discursivas, o contexto em que o processo de "modernização" dos estádios surge é bem diferente. Os primeiros estádios brasileiros eram setorizados por estratos de renda, tal como os modelos europeus. Os melhores setores eram destinados aos dirigentes e à classe média, enquanto atrás dos gols, com pior ângulo de visão, eram destinados os ingressos mais baratos. A distribuição espacial e setorizada dos espectadores foi o esteio do desenvolvimento de diferentes culturas torcedoras (Santos, 2014).

$\mathrm{Na}$ atualidade, por sua vez, a reforma dos estádios e sua transformação em arenas integra o processo de gentrificação do espaço público esportivo (Hollanda, 2014) que tem em seus alicerces alguns fenômenos antigos e outros novos: espetacularização da prática desportiva que passa a se adequar aos critérios televisivos, tornando prescindível ou colocando em segundo plano a presença do público nos estádios; a mobilização do discurso da violência para alterar o perfil de torcedor que frequenta as praças esportivas, substituindo o torcedor organizado e de baixa renda pela família consumidora de espetáculo. As arenas têm por princípio alterar o quadro de massificação que herdara dos padróes construtivos da década de 1950, "organizando" a separação, hierarquização e atomização das torcidas, processo bem observado por Bernardo Buarque de Hollanda na última grande reforma do Maracanã (Hollanda, 2014).

Esse projeto tem como pano de fundo a eleiçâo das torcidas organizadas como grupo social criminalizado, inimigo público interno que precisa ser controlado para dar lugar à ressignificação do torcedor e do ato de torcer que as novas arenas trazem 
embutidas em seus padróes construtivos. Este processo, porém, não é absolutamente recente. No futebol a contenção das torcidas e controle das organizadas fora a reação oficial do governo britânico ao hooliganismo na Inglaterra nos anos 1990, ${ }^{6}$ que influenciou não só a estética dos estádios como instituiu um conjunto de instrumentos normativos que abriu espaço para a difusão paulatina de uma política de controle social como via para a contenção da violência nos estádios. No Brasil, a imprensa esportiva difundiu este modelo promovendo a mesma estratégia inglesa: vilanização das torcidas organizadas ${ }^{7}$ que comparecem ao debate público sobre a violência sem qualquer poder de fala, como o outro a ser eliminado (Lopes, 2013). Concretamente, estes processos vêm causando o embranquecimento paulatino das arquibancadas, algo já apontado nos anos 1980 em face do encarecimento dos ingressos num país de maioria negra empobrecida.

As manifestaçôes de racismo integram, pois, as transformações que atingem tanto o futebol como o conjunto da sociedade brasileira. À luz da institucionalidade que vem sendo hegemonicamente construída, o futebol, um dos principais espaços de lazer popular, precisa ser controlado pela polícia; as torcidas organizadas precisam ser disciplinadas ou até mesmo extintas; a arquitetura dos estádios engendra a transformação cultural do ato de torcer; por fim, a conversão do torcedor em consumidor exclui "tacitamente" grande parte da população negra.

As transformaçóes aqui tratadas estão intimamente relacionadas com o debate geral sobre violência, cuja lógica se ancora na eleição de inimigos internos; na classificaçáo dos sujeitos a serem eliminados apenas a partir de seu comportamento desviante; na adoção de uma retórica estigmatizante e belicista que induz pensar os estádios como lugar de perigo e desordem; na animalização do torcedor organizado, metáfora de uma natureza que precisa ser civilizada (Lopes, 2013).

Todos estes elementos integram um processo ampliado de incremento do controle social e de securitizaçáo da vida e da política nos territórios urbanos, que tem no corpo negro o seu alvo preferencial. A segurança dos estádios propugnada

6. Em 15 de abril de 1989, a superlotação de um estádio em Sheffield vitimou 96 torcedores do Liverpool, fato conhecido como tragédia de Hillsborough. O Relatório Taylor, elaborado para dar fundamento ao conjunto de medidas de segurança subsequentes à tragédia, desresponsabilizava autoridades locais, ao mesmo tempo que autoridades públicas apontavam a torcida do Liverpool como principal causadora das mortes. Este relatório tornou-se uma espécie de manual com as diretrizes centrais para transformar o futebol inglês, sendo estas seguidas em todo o mundo: reformulação estrutural dos estádios, mudança do perfil do público torcedor e transformação dos clubes em empresas (Santos, 2014). Em 2012, porém, após o vazamento de documentos referentes ao episódio, o Estado britânico reconheceu o erro ao apontar equivocadamente os hooligans como responsáveis pelas mortes em Hillsborough. A este respeito ver: <http://goo.gl/Qwsyid>.

7. Até os anos 1940, cada clube tinha apenas uma torcida organizada, comandada por um chefe, que tinha por função precípua uniformizar e organizar o ato de torcer. Estas torcidas integravam um projeto pedagógico que pretendia enquadrar moralmente as massas presentes nos estádios, num modelo festivo assemelhado às escolas de samba. Na década de 1960 começam a surgir as torcidas jovens, demarcando um novo modo de torcer, vaiando jogadores, dirigentes e chefes de torcida. Nos anos 1980 estas torcidas crescem de forma vertiginosa, sendo associadas comumente à delinquência e a violência (Hollanda, 2014). As torcidas jovens constituem hoje uma das poucas experiências de organização coletiva da juventude negra periferizada nas grandes cidades. 
pelas formas arquitetônicas da exclusão nada mais é que segurança para consumo ou, em outros termos, a promoção de espaços seguros para consumo (Campos, 2014a). Estas formas políticas de controle vêm redefinindo os usos do espaço urbano, no qual o estádio é apenas mais um equipamento, alterando o panorama a partir do qual as tensóes e conflitos raciais se reproduzem e intensificando as manifestaçóes de racismo na conjuntura recente.

\subsubsection{A questão urbana e os dilemas da raça na era dos grandes eventos}

A Copa do Mundo deixou legados. Quanto a isto parece haver consenso entre críticos e entusiastas dos grandes eventos. De acordo com o governo brasileiro, obras de mobilidade urbana e infraestrutura garantiriam melhoria substancial do bem-estar da populaçáo citadina. As manifestaçóes de junho de 2013, porém, revelaram um profundo dissenso com relação aos rumos das políticas urbanas e suas tendências recentes. Revelou ainda um profundo mal estar vivido cotidianamente, o qual, se não é resultado dos grandes eventos, deve a estes a sua intensificação nos últimos anos. E é nesse mal estar que a questáo racial apareceu articulada com a questáo urbana e as políticas de controle social que se disseminaram ao longo desse período.

Enquanto parte das manifestações apontavam para os dilemas de uma cidade privatizada pelo automóvel, a morte de Amarildo e as incursōes policiais na periferia das grandes cidades colocava em evidência a constituição de uma cidade de exceção, escorada na escalada repressiva, na segregação espacial e na vigilância. A realização dos jogos olímpicos e da Copa é a desembocadura desta concepção de urbe e de política urbana que vem ganhando espaço entre as administraçōes municipais ao longo dos últimos anos.

Os grandes eventos esportivos amplificam tendências em curso na medida em que se sustentam numa autonomia política e jurídica construída há mais de um século pelos organismos internacionais que o promovem, fato que lhes permite construir institucionalidades próprias, formas de exercícios de poder que radicalizam o caráter autoritário das políticas urbanas, dando forma mais definida ao que alguns autores chamam "cidade de exceção" (Vainer, 2011; Oliveira, 2013). A agilidade e a eficácia exigidas para uma cidade competir são obtidas a partir de um consenso forjado num patriotismo cívico e na honra aos compromissos assumidos. O contrato substitui a política e o espaço público em que ela se realiza.

As medidas institucionais construídas para viabilizar esses eventos são inúmeras. Indicaremos aqui apenas as mais importantes para o tema em debate: instrumentos e medidas de controle do espaço público foram construídos para proteger os interesses das marcas relacionadas aos grandes eventos - Lei oㅡ 12.035/2009 (Brasil, 2009); à União fora atribuída a responsabilidade civil por quaisquer danos provocados à Fifa e seus funcionários, relacionados a incidente ou acidente que envolva a segurança dos eventos - Artigo 23 da Lei no 12.663/2012, lei geral da Copa (Brasil, 2012a); 
crimes específicos foram criados para coibir a pirataria - Artigos 30 a 36 da Lei no 12.663/2012 (op. cit.); inúmeras condiçôes para o acesso e a permanência nos locais de competiçáo e suas imediaçóes foram impostas, fato que motivou a repressão policial durante os protestos de rua de 2013. Além disso, o projeto de lei que tramitava no Senado - PLS no 728/2011 (Brasil, 2011a), conhecido como o AI-5 da Copa, definia crimes e infraçôes administrativas com vistas a incrementar a segurança na Copa do Mundo 2014, estabelecia a limitação ao direito de greve de categorias consideradas essenciais e a criação de oito novos tipos penais, incluindo-se o crime de terrorismo (Oliveira, 2013).

Em suma, estas iniciativas são expressão de uma forma já consolidada de fazer política, em que a exceção surge, a um só tempo, como paradigma e técnica de governo, como veremos de forma mais detida adiante. A adoçáo de medidas de exceção como paradigma de governo, por sua vez, cria as condiçóes para transformar os megaeventos esportivos em estratégia de desenvolvimento (Oliveira, 2013).

Exemplos concretos surgiram na conjuntura recente e podem ajudar a ilustrar melhor esse fenômeno. Um expediente utilizado largamente pelas prefeituras neste período foram as açôes de higienização social. ${ }^{8}$ Em pelo menos seis cidades-sede da Copa do Mundo, moradores de rua foram expulsos e/ou impedidos de transitar e permanecer em locais próximos dos estádios. Embora as remoçóes compulsórias não sejam fatos inéditos, a promoção de megaeventos esportivos tem intensificado estas medidas, legitimadas oficialmente na associação entre corpos negros, desordem urbana e insegurança pública. A presença de indesejáveis surge como motivo para a desocupação das ruas e redução das atividades econômicas. A degeneração das ruas tem cor, em termos práticos.

O caso do morador de rua Rafael Braga Vieira é bem emblemático da violência institucionalizada e consentida por parte do Estado nesse processo de higienizaçáo das cidades. Em junho de 2013, Rafael, negro, pobre, 28 anos, catador de latinha, foi condenado a 5 anos de prisão por carregar na mochila duas garrafas com desinfetante e água sanitária. Preso em flagrante durante uma das grandes manifestaçóes de rua de junho de 2013, a acusação feita contra Rafael foi baseada no artigo 16, inciso III da Lei no $10.826 / 03$ (Brasil, 2003), que versa sobre porte de material explosivo. Ele foi, até hoje, a única pessoa presa e condenada em decorrência das manifestaçôes de junho de 2013. A denúncia elaborada pelo Ministério Público dizia que Rafael portava duas garrafas de coquetel molotov, fato negado pelo laudo técnico do Esquadrão Antibombas da Polícia Civil do Rio de Janeiro,

8. Os casos mais graves de higienização social são de Salvador. Desde os preparativos para a Copa das Confederações o Movimento Nacional de População de Rua (MNPR) tem denunciado remoções forçadas e subtração de pertences de moradores de rua. A Defensoria Pública ajuizou ação na Justiça requerendo a abstenção da prefeitura de Salvador de praticar as ações higienistas em curso na cidade, por meio de medidas como lançamento de jatos d'água, remoção para comunidades terapêuticas ou para municípios vizinhos. A este respeito ver Azevedo (2014). 
que considerou ser ínfima a possibilidade de os objetos encontrados em sua mochila funcionarem como explosivo.

A manutenção de uma sentença condenatória, mesmo diante da total impossibilidade de praticar um crime pela ausência do elemento central que o configuraos explosivos -, expóe as chagas de um sistema penal explicitamente seletivo, racista, classista, ilegal e ilegítimo. Rafael fora punido por ser negro, pobre, reincidente. E fora preso, sobretudo, para dar exemplo, num contexto em que a repressão tinha nítido sentido intimidatório.

Porém, Rafael Braga não foi o único a viver na pele o recrudescimento do Estado penal. No dia 24 de junho de 2013, o complexo de favelas da Maré, habitado por 130 mil pessoas, fora invadido por policiais do BOPE em reação a supostos roubos praticados por moradores da comunidade, segundo a versão oficial. Durante a ação, um sargento do Bope morreu, fato que gerou uma reação violenta da polícia que, em 24 horas, já havia assassinado nove pessoas. Naquela incursão casas foram invadidas enquanto tiroteios habitavam as ruas desertas. Após manifestação que reuniu quinhentas pessoas da comunidade e a pressão de órgãos de direitos humanos, a operação policial findou, deixando para trás não só os nove mortos, mas a memória viva do medo e do terror.

Em fevereiro deste ano, a Maré volta a aparecer no noticário nacional. Policiais militares e Unidades da Polícia Pacificadora (UPPs) eram atacados, segundo a versão oficial, por uma facção do Comando Vermelho. Em virtude da realização da Copa, o governador do Estado solicita o envio de tropas das Forças Armadas até o fim do torneio, quando as UPPs seriam definitivamente implantadas no complexo. Em atendimento ao pedido, a Presidência da República assina decreto de Garantia da Lei e da Ordem, ${ }^{9}$ autorizando o envio das forças armadas, reeditando roteiro bem definido desde os anos 90 nas operaçóes militares no Rio. ${ }^{10}$

Nos 15 dias anteriores à ocupação pelos militares, 16 pessoas haviam morrido em supostos confrontos com a polícia. Ironicamente, dois dias após a ocupação militar do território, o golpe de 64 faria 50 anos, com tanques e soldados tomando as ruas da Maré. Na paz armada construída para devolver a segurança à comunidade as denúncias de agressōes e violações de direitos são inúmeras, conforme veiculado em diversas reportagens efetuadas in $l o c 0^{11}$ por diferentes veículos de comunicação. Mas, além das violaçôes ilegais, há as legalizadas, caso do juiz da 39a Vara Criminal da capital, que expediu mandado de busca e apreensão coletivo que autorizou a

9. Em 19 de dezembro de 2013 o Ministério da Defesa publica a Portaria Normativa no 3.461/MD (Brasil, 2013) que disciplina o uso das forças armadas em operações de garantia da lei e da ordem nos casos em que a sua preservação esteja sob ameaça, esgotadas as vias previstas no Artigo 144 da Constituição Federal (Brasil, 1988).

10. Em abril, 200 fuzileiros navais e 2050 militares da Brigada de Infantaria Paraquedista do Exército entraram em ação no complexo.

11. A este respeito ver Araujo (2013) e Merlino e Castor (2014). 
polícia do Rio a entrar em todas as residências das favelas Nova Holanda e Parque União. Em resumo, na favela todos são suspeitos. A Maré é a demonstração nítida de que o sistema penal atualmente compreende não só o cárcere, mas as tecnologias de controle e vigilância e uma gestâo policial da vida (Batista, 2012).

Para as comunidades ${ }^{12}$ destituídas da chance de participar do evento, sua realização traduziu-se em convivência com a militarizaçáo do espaço urbano, o Apartheid racial que impóe limites aos direitos de ir e vir e ao direito à vida, pois não há outra consequência possível diante de uma narrativa que dá forma a uma guerra civil oficialmente declarada e que tem virado rotina em comunidades e morros em todos os Estados que vêm adotando políticas de segurança e ocupaçáo de território inspiradas no modelo fluminense. $\mathrm{O}$ recurso às forças armadas, embora traduzido como medida de caráter excepcional, tem sido a regra nestes espaços. E o terrorismo internacional passou a figurar como justificativa para a transformação da exceção em regra.

No contexto da geopolítica urbana têm sido muito utilizados pela mídia termos como reconquista do território, guerra contra o tráfico, retomada do Estado etc. O aparato estatal desenvolve suas políticas de segurança através da localização dos territórios a serem reconquistados, instaurando uma geografia do avanço das forças da ordem. As metáforas bélicas escondem, porém, um detalhe relevante: os considerados territórios inimigos, controlados por milícias e traficantes, são territórios negros. A mídia constrói aqui o enredo épico e maniqueísta das operaçóes, suporte ideológico que as táticas de guerra necessitam para serem legitimadas (Souza, 2012). E toda guerra, para se legitimar, necessita da eleição de um inimigo interno, que opera na legitimaçáo da demanda por repressão e ordem e nos golpes de Estado. Com uma diferença precípua: os comunistas de ontem são os "bandidos" de hoje.

Modelos de segurança pública como as UPPs, por outro lado, possuem uma geograficidade que os interliga a uma política de valorização de territórios urbanos. Como seu custo é demasiadamente alto para ser reproduzido em larga escala, é na interlocuçáo da lógica econômica com o racismo e o classismo que ela ganha renovado sentido. As áreas residenciais da Zona Sul carioca perceberam o maior número de intervençôes, abrindo espaço para o incremento exponencial da renda da terra urbana e a gentrificação da população originária. ${ }^{13}$

12. A Maré está próxima de três importantes vias que ligam as zonas Oeste, Norte e Sul do Rio ao Aeroporto Internacional Tom Jobim: a Linha Vermelha, Linha Amarela e Avenida Brasil. Sua localização estratégica explica, portanto, a sua ocupação às vésperas da Copa do Mundo. Após a efetivação da ocupação, 850 homens fariam patrulha nos territórios negros da Maré, garantindo assim a segurança daqueles que transitariam pelas imediações da comunidade durante a Copa do Mundo.

13. Estudo realizado pela Fundação Getúlio Vargas utilizando dados da PNAD 2009 e do censo de favelas realizado pelo Estado do Rio de Janeiro em 2008, mostram que o preço dos aluguéis nas comunidades atendidas pelas Unidades de Polícia Pacificadora (UPPs) foi superior à expansão dos aluguéis em bairros tradicionais. A este respeito ver FGV (2012). 
A tentativa de oferecer segurança à população integra, pois, uma geopolítica urbana que expressa um conflito complexo de territorialidades e uma distinção entre os que devem ser protegidos e os que devem ser vigiados, mediada por uma tecnologia de poder que vem servindo como argamassa para a legitimaçáo da militarizaçáo da questão urbana. Assim, já não podemos mais falar de prisão nos moldes em que ela foi classicamente pensada. A prisão dos tempos atuais se funde com as periferias negras dos grandes centros urbanos, subproduto da indústria de controle do crime, numa economia que articula medo, câmeras, vigilâncias e arquiteturas.

As arquiteturas do medo, a subjetividade paranoica e o racismo institucional

Entre dezembro de 2013 e janeiro de 2014, a juventude periférica, majoritariamente negra, pobre, entoando músicas do funk ostentação, resolveu cruzar as fronteiras da segregação e foi parar na delegacia. Sem cometer qualquer crime, os jovens foram revistados, impedidos de entrar, convidados a se retirar dos estabelecimentos, recebidos com bombas de gás e bala de borracha. A polícia foi mais uma vez acionada como mediadora entre a classe alta e as classes perigosas, pois o racismo brasileiro só admite a presença do elemento negro quando ele é mediado ora pela polícia $^{14}$ ora pela relação servil.

A disseminação da vigilância e a segregação espacial reforçam a violência entranhada nas próprias formas urbanas que rejeitam os indesejáveis (Melgaço, 2010). O medo fornece o princípio do shopping center, repositório das sociabilidades contemporâneas, que representa o estabelecimento de fronteiras. No shopping não cabem as "classes perigosas", cuja segregação é essencial para que a sua lógica exclusivista torne-se eficaz. Sua essência é segregadora. Não basta, porém, ter poder de compra para se socializar neste espaço onipresente nos centros urbanos, como os rolezinhos apontaram neste período.

O funk ostentação que inspira essa juventude reclama consumo e luxo como fonte de prazer. Porém, essa juventude não quer apenas se apropriar simbolicamente dos valores que o shopping representa. Ela quer o seu espaço físico. E esta pretensão foi lida pela polícia, governos estaduais, clientes de classe média e administradores de shopping como uma violência. Os rolezeiros, logo taxados de vândalos, roubavam da elite o direito exclusivo de consumir.

Os rolezinhos retomam a imagem do arrastão, fobia social que provoca medo e repulsa movidos pelo receio de que ocorra uma espécie de vingança da história, protagonizada por uma negritude identificada como ser selvagem e incivilizado. A defesa incondicional da propriedade contra ladróes em potencial tem raiz na história. Foi a disseminaçáo do medo, o receio de uma radicalização negra que conduziu a

14. Pesquisa Datafolha realizada em janeiro de 2014 apontou que $82 \%$ dos paulistanos eram contra os rolezinhos; $80 \%$ eram favoráveis às liminares obtidas pelos shoppings e $72 \%$ eram favoráveis à ação da polícia militar para impedi-los de acontecer. A este respeito ver Leite (2015). 
classe senhorial à produção de imagens e representaçóes hiperbólicas do "popular" em geral e do negro em particular. $\mathrm{O}$ medo do abolicionismo e do haitianismo como possibilidade histórica permitiu que esta classe senhorial monopolizasse a violência legítima em seu favor ${ }^{15}$ (Batista, 2003).

$\mathrm{Na}$ esteira do proibicionismo, da securitização da vida, do reforço à produção de estigmas sociais que conduzem à disseminação de práticas racistas, outras medidas foram tomadas, as quais enumeraremos em rápida síntese: $i$ ) o cercamento de morros e favelas ao longo dos últimos anos; ii) a aprovação no Rio de Janeiro da Lei no 6.717/2014 (Rio de Janeiro, 2014a), que proíbe o uso de qualquer acessório que esconda ou inviabilize a exposição do rosto em estabelecimentos comerciais, públicos ou abertos ao público; e iii) por fim, aprovação da Lei no 13.022/2014 (Brasil, 2014b), que autoriza guardas municipais a portarem armas de fogo.

Numa sociedade neurotizada pela incerteza e insegurança, o medo tem sido, portanto, o principal fundamento subjetivo instituído para amplificar os inúmeros dispositivos de controle social, convertendo o afastamento do "elemento selvagem" em princípio ordenador de toda a sociedade. Assim, embora o ordenamento jurídico cível considerasse o negro como coisa, o sistema penal o identificava como sujeito. A história da vigilância e do sistema policial tem nessa relação aparentemente ambígua a sua matriz histórica (Batista, 2003).

Esse medo, portanto, produz vítimas, pois demanda castigo, punição exemplar e penas mais severas, constituindo aquilo que Vera Malaguti Batista denomina "adesão subjetiva à barbárie" (Batista, 2012). Contudo, não se trata apenas de uma adesão construída de forma difusa e descontrolada. Há uma economia que gira em torno dessa subjetividade paranoica que interliga mercado de segurança, espaços exclusivos e o sistema político-eleitoral. Todos estes elementos estão ancorados na política do medo (Souza, 2012).

A inculcaçáo do desejo de punir tem produzido uma subjetividade disciplinar e moralista, que solicita publicamente o encarceramento e a punição (Batista, 2012). De acordo com pesquisa realizada pelo Ibope mais de $70 \%$ da população brasileira mostra-se favorável à redução da maioridade penal. $\mathrm{O}$ assunto voltou à pauta institucional em razão do apelo popular por punição, do papel da mídia, de projetos de lei apresentados no Congresso ${ }^{16} \mathrm{e}$ da sua incorporação em programas

15. Em 1825, um decreto que criou cargos de comissário dava forma à arquitetura do sistema policial contemporâneo: impedia ajuntamentos, reprimia a vadiagem, cadastrava capitães do mato, enunciava a erradicação de quilombos e instituía açoites em locais públicos (Batista, 2003).

16. Em fevereiro de 2014, a PEC 31/2011 (Brasil, 2011b), de autoria do senador Aloisio Nunes Ferreira, entrou na pauta de votação da Comissão de Constituição e Justiça do Senado. A PEC propunha reduzir a maioridade penal de 18 para 16 anos para certos tipos penais ou em alguns casos de reincidência. A maioria dos senadores, porém, votou contra a proposta por considerarem cláusula pétrea o dispositivo constitucional que estabelece a maioridade no Brasil, além de a PEC violar direitos das crianças e dos adolescentes. A despeito da votação, a medida tem forte apoio no Congresso. Em 2011, foi criada a Frente Parlamentar pela redução da maioridade penal, com o apoio de mais de 200 congressistas. 
de candidatos em período eleitoral. A maioridade penal fora reduzida em 54 países no mundo e em todos eles não há registro de redução da violência. Espanha e Alemanha optaram pela redução da maioridade, mas seus efeitos inócuos e deletérios os fizeram voltar atrás. Atualmente $70 \%$ dos países no mundo estabelecem 18 anos como idade penal mínima (Betto, 2014).

Ante a possibilidade de não encarcerar, há o clássico recurso ao justiçamento privado, ${ }^{17}$ em que o corpo é o lugar onde se realiza o rito sacrificial punitivo. Foram registrados no ano de 2014 mais de 1.950 casos de linchamento que têm, entre uma de suas causas, o racismo. Dados do Núcleo de Estudos sobre Violência (NEV/USP) levantados a partir de dados da imprensa apontam para 1.179 casos de linchamento verificados entre 1980 e 2006. Como pondera José de Souza Martins, linchamentos, saques e quebra-quebras são comportamentos sociais coletivos desprovidos de organização e que têm no corpo negro sua vítima predileta. Ainda que não se possa revelar com precisão se as causas dos linchamentos são circunstanciais ou estruturais, fato é que, mesmo neste último caso, as causas imediatas do justiçamento privado já estão, em regra, presentes no cotidiano das relaçóes sociais (Martins, 1995).

Foi como denúncia e contraposição ao Estado penal que confina, mata e desestrutura famílias negras que entidades do movimento negro e movimentos sociais realizaram a II Marcha (Inter)nacional contra o genocídio da população negra. Iniciada na Bahia em 2012 pela "Campanha Reaja ou será morto, reaja ou será morta”, em sua segunda edição, a Marcha foi realizada no dia 22 de agosto de 2014 em 18 Estados brasileiros e 15 países, reunindo aproximadamente $60 \mathrm{mil}$ pessoas, segundo a organização. Esta campanha vem denunciando desde 2005 a gestão policial da vida naquilo que ela tem de central: o genocídio do povo negro, sobretudo sua juventude, conduzido por um Estado supremacista branco.

De acordo com o Mapa da Violência 2014, no período 2002-2012 houve queda da taxa de homicídios da populaçáo branca e incremento da vitimizaçáo da população negra. Enquanto entre os brancos houve queda de $24,8 \%$ na taxa de vitimização, entre os negros houve aumento de $38,7 \%$ no período supracitado. Como a taxa nacional de homicídios permaneceu estável no período (passou de 28,9/100 mil habitantes para 29/100 mil), pode-se falar que a lógica da violência socialmente produzida teve um elevado incremento do seu caráter seletivo (Waiselfisz, 2014). Traduzindo em números, no período $2002-2012$ morreram $72 \%$ mais negros que brancos.

17. Em São Paulo, caso emblemático envolveu André Luiz Ribeiro, professor negro de história que, acusado de roubo, foi acorrentado num poste e cercado por 20 pessoas que começaram a agredi-lo. Bombeiros que passaram pelo local impediram que 0 ato continuasse, obrigando o agredido a dar aula sobre revolução francesa como prova de sua profissão. Como fora apontado pelo dono do estabelecimento como autor do roubo, André Luiz Ribeiro foi preso em flagrante, permanecendo encarcerado por dois dias. A este respeito ver Granjeia (2014). 
Parte significativa das mortes é produto de uma espécie de pena de morte socialmente consentida e legalizada desde a ditadura militar, quando fora instituído oficialmente o auto de resistência nas rotinas operacionais da força policial (Souza, 2010). Os autos de resistência constituem uma espécie de licença legítima para matar e, embora já existissem como prática desde o século XIX, foram legalizados pela ordem de serviço no 803 , de 2 outubro de $1969 .{ }^{18}$ A sua regulamentação fez parte de um conjunto de medidas autoritárias e excepcionais, da mesma natureza da lei de segurança nacional - Decreto-lei no 898/1969 (Brasil, 1969), da legalização da pena de morte, prisão perpétua e da prática clandestina de extermínio. Em suma, os autos de resistência serviram historicamente para mascarar execuçóes sumárias, chegando a ser utilizados, entre os anos 1995 e 1999, no Rio de Janeiro, como critério para obtenção de gratificação de desempenho (Souza, 2010).

As estratégias de defesa dos policiais que conseguiram inúmeras absolviçóes do Tribunal do Júri consistiam na comprovação de que a vítima era criminosa. Assim, implicitamente, subsiste a ideia de que "bandido bom é bandido morto." Em outros termos, estamos diante de um dispositivo biopolítico, produto de um Estado de exceção erigido para eliminar os descartáveis da sociedade.

Iniciativa que tramita na Câmara dos Deputados, o PL 4471/2012, ${ }^{19}$ tenta pôr fim aos autos de resistência, prevendo a investigação das mortes e lesóes corporais provocadas por policiais em atividade. Dados do Fórum Brasileiro de Segurança Pública (FBSP, 2013), que reúne dados oficiais de órgãos estaduais e federais, apontam que 1890 pessoas morreram em confronto com a polícia no ano de 2012, média de cinco pessoas por dia.

Estudo feito pelo Grupo de Estudos sobre violência e administração de conflitos (GEVAC/UFSCAR) sobre mortes provocadas por policiais do Estado de São Paulo entre 2009 e 2011 aponta que 61\% das vítimas são negras e jovens, entre 15 e 29 anos. Em outras palavras, morrem três vezes mais negros que brancos. Os policiais autores das mortes são majoritariamente brancos (79\%) e, dos inquéritos instaurados, nada menos que $94 \%$ foram concluídos sem indiciamento. Entre os argumentos inscritos nos inquéritos, $73 \%$ consideraram não haver homicídio cometido por policiais. Este mesmo estudo aponta que é sobre a população negra que recai a maior vigilância policial, em consonância com a associação do corpo negro à criminalidade. No Estado de Sáo Paulo, no ano de 2012, para cada 100 mil

18. A Ordem de Serviço ำ 803, de 2 de outubro de 1969, foi expedida pela Superintendência da Polícia Judiciária do antigo Estado da Guanabara. Este dispositivo instituiu legalmente os "autos de resistência", nome dado às ocorrências que tenham dado resultado a mortes e ferimentos oriundos de confronto com a polícia.

19. O PL no 4471/2012, de autoria do Deputado Paulo Teixeira (PT-SP), tem por objeto a alteração dos Artigos 161, 162, 164, 165, 169 e 292 do Código de Processo Penal. Estes dispositivos regulam a apuração de casos envolvendo letalidade no emprego de força policial. 
negros, 35 foram presos em flagrante. De outro lado, para cada 100 mil brancos, 14 foram presos em flagrante (Sinhoretto, Silvestre e Schilittler, 2014).

A população carcerária brasileira, segundo o Conselho Nacional de Justiça (CNJ), atingiu 711.463 presos, dos quais 147.937 estão em prisão domiciliar. Deste total, o número de presos provisórios - aqueles que aguardam julgamento definitivo - é de 32\% (CNJ, 2014b). Estes números colocam o Brasil em terceiro lugar no ranking de países com maior população prisional, atrás apenas de Estados Unidos e China. Se considerarmos ainda o número de mandados de prisão em aberto, este número pode saltar para 1.085.454 pessoas em cárcere e/ou passíveis de encarceramento (op cit.). Em 9 Estados da federação há mais presos provisórios do que condenados, submetidos a condiçóes degradantes e sem direito a ampla defesa, dado que $95,4 \%$ das comarcas no Brasil não possuem defensor público ou o possuem em número insuficiente (Moura et al., 2013). A exceção, mais uma vez, vira regra.

Num contexto de arrefecimento dos conflitos raciais, do incremento da exposição pública dos racismos de sempre, o mito da democracia racial se reconfigura em duas direçóes: de um lado, o crescimento do racismo institucional permite que a ideia de um país onde haja racismo sem racistas ganhe expressão; de outro, os fatos aqui narrados vão na contramão do elogio aparente à participação da raça na construção da sociedade brasileira. Trata-se, na prática, de uma retomada da perspectiva negativa em relaçáo à participação do negro na sociedade, resposta ao avanço marginal da negritude nos espaços antes exclusivos dos brancos. Esta perspectiva desnuda a construçáo do nacional que se ancora na necessidade de absorver e integrar os negros sem contaminar a imagem de uma nacionalidade ocidental branca (Arruti, 1997). Para tanto, o nacional se serve de políticas de segurança pública e privada que isolam, fragmentam, incriminam e exterminam negros em massa, sob os auspícios da própria lei.

\subsection{Intolerância religiosa}

O racismo, que se expressa de diversas formas na sociedade brasileira, ganha um contorno diferente no que se refere à manifestação da fé. O tema da intolerância religiosa ganhou destaque em 2013 e início de 2014, tanto no plano estatal (legislativo, judiciário e executivo), como na sociedade brasileira. Historicamente, as religiōes de matriz africana, como a umbanda, candomblé e jurema, estiveram associadas a coisas ruins, "demonizadas", ligadas ao "diabo" ou mesmo colocadas no plano da ilegalidade.

O enfrentamento às religióes de matriz africana não foi apenas simbólico e, sim, uma política de Estado, especialmente na primeira metade do século XX, quando a perseguição foi ainda mais intensa e violenta. Os praticantes dessas 
religióes eram perseguidos e criminalizados pelo Estado brasileiro e por religiōes hegemônicas. ${ }^{20}$ Apesar de não ter uma legislaçáo específica proibindo a religião, a prática era considerada crime contra a saúde pública, já que, segundo esse raciocínio, prejudicava a saúde mental da população. Os terreiros eram considerados ambientes propícios à loucura (Silva, 2012). A criminalização ocorre de forma mais sistematizada especialmente a partir do Estado Novo, com a criação de Seção de Tóxicos e Mistificaçôes, em 1934, com o objetivo específico de investigar esse tipo de "crime". Os terreiros (considerados templos religiosos dessas religióes) eram obrigados a se registrar junto às Delegacias de Jogos e Costumes, vinculadas à Secretaria de Segurança pública. Em Porto Alegre, por exemplo, esta exigência de registro perdurou até a década de 1990.

É nos anos 2000 que a pauta da intolerância começa a adquirir novos contornos e somente em 2007 esse tema passa a ser tratado como política de Estado, especialmente com a promulgação da Lei Contra a Intolerância Religiosa Lei no 11.635/07 (Brasil, 2007a), instituindo o dia 21 de janeiro como o dia de Combate a Intolerância. Apesar desse primeiro passo, esse tema ainda encontra muitos empecilhos para efetivação, especialmente em relaçáo ao racismo presente nos imaginários construídos sobre estas religióes.

Nesse sentido, em 2013 dois projetos de lei (PL) tramitados no Congresso Nacional chamaram a atenção sobre o tema da intolerância religiosa. O primeiro deles é o PLS no 114/1997, de autoria do ex-senador Abdias do Nascimento, que altera a Lei de Ação Civil Pública (Brasil, 1985), incluindo o Ministério Público e/ou organizaçóes da sociedade civil (com agenda racial) como legitimadas para ajuizar ação de fazer ou não fazer, para a preservação da honra e dignidade de grupos raciais, étnicos e religiosos. Na prática, o PLS no 114/1997 inclui a intolerância religiosa como passível de ser combatida via Ação Civil Pública. O outro PLS se refere à Proposta de Emenda Constitucional (PEC) no 99/2011 (Brasil, 2011c), de autoria do deputado federal João Campos - membro da Frente Parlamentar Evangélica no Congresso Nacional - que propóe a inclusão de "associaçóes religiosas de âmbito nacional” como legitimadas para propor Açáo Direta de Inconstitucionalidade (ADin), alterando o Artigo $103,{ }^{21}$ da Constituição Federal de 1988.

20. Em 1952, a Igreja Católica criou a Secretaria Nacional em Defesa da Fé com a finalidade precípua de enfrentar ao crescimento da umbanda e demais religiões mediúnicas, fazendo uma associação entre essas religiões com a miséria moral e espiritual da população negra, a proliferação de doenças, herdando a ignorância trazida pelos negros escravizados oriundos do continente africano (Isaia, [s.d.]).

21. Artigo 103 - podem propor a ação direta de inconstitucionalidade e a ação declaratória de constitucionalidade: i) o Presidente da República; ii) a Mesa do Senado Federal; iii) a Mesa da (âmara dos Deputados; iv) a Mesa de Assembleia Legislativa; v) a Mesa de Assembleia Legislativa ou da (âmara Legislativa do Distrito Federal; vi) o Governador de Estado; vii) o Governador de Estado ou do Distrito Federal; viii) o Procurador-Geral da República; ix) o Conselho Federal da Ordem dos Advogados do Brasil $(\mathrm{OAB}) ; x$ ) partido político com representação no Congresso Nacional; e xi) confederação sindical ou entidade de classe de âmbito nacional (Brasil, 2004). 
As duas propostas legislativas têm em comum o fato de instituiçóes religiosas poderem apresentar, junto ao judiciário, açôes referentes às demandas cujos interesses estejam relacionados a elas. Porém, diferem exatamente na legitimidade da propositura. Enquanto o PLS no 114/1997 prevê a possibilidade de a intolerância religiosa ser combatida via Ação Civil Pública, o que permitiria proteção e garantia constitucional da liberdade de manifestação da fé, por outro lado, a PEC 99/2011 propôe que instituiçóes religiosas possam determinar a constitucionalidade de ato legislativo, o que fere a laicidade do Estado, preconizada no Artigo 19, da Constituição Federal de 1988. A possibilidade de intervenção por parte de instituições religiosas representaria a quebra do processo de secularização e separação histórica entre Estado e religião.

A laicidade do Estado não significa uma postura de indiferença ou omissão por parte dos agentes estatais em relação às instituiçóes religiosas. A laicidade representa a impossibilidade de se estabelecer uma relação de dependência ou aliança em relação às mesmas. Porém, também é obrigação do Estado garantir o direito constitucional de que cada pessoa possa praticar ou professar sua fé. Justamente o objetivo preconizado no PLS no 114/1997.

Outro ponto levantado pela PEC no 99/2011 é a limitação ao direito de entidades religiosas de pleitear Açôes Diretas de inconstitucionalidade (Adin). Conforme se depreende da proposta, esse direito fica restrito às entidades de caráter nacional, cujo conceito não se encontra definido nem em doutrina específica, nem em marcos legais. Levando em consideração as mais diversas formas de violência que as religiōes de matriz africana sofrem, o reconhecimento destas como de caráter nacional fica a critério de uma discricionariedade circunscrita em sociedade marcadamente racista, cujos valores afro-religiosos ficam relegados ou à ignorância ou ao preconceito.

A PEC no 99/2011 continua em tramitação no Congresso Nacional, tendo recebido em 27 de março de 2013 parecer favorável na Comissão de Constituição e Justiça; em 11 de junho de 2013, foi criada uma Comissão Especial destinada a proferir parecer à proposta. O PLS de Abdias do Nascimento já foi incorporado ao ordenamento jurídico brasileiro em 25 de abril de $2014 .{ }^{22}$

No âmbito jurídico, já no início de 2014, o Ministério Público Federal do Rio de Janeiro ingressou com uma Ação Civil Pública contra a Google Brasil Internet Ltda. (Rio de Janeiro, 2014b), solicitando a retirada de conteúdos ilícitos hospedados na internet (intolerância e discriminação por motivos fundados na religiosidade de matrizes africanas). Em 24 de abril 2014, o juiz da 17a vara do 
Tribunal Regional Federal da 2 $2^{a}$ Regiáo indeferiu o pedido, argumentando pelo direito à liberdade de expressão, de reuniấo e de religião.

Em 9 de maio 2014, o MPF/RJ interpôs recurso sintetizando os argumentos presentes na decisão do magistrado do TRF/RJ. Em síntese, o magistrado alega que: i) "cultos afro-brasileiros não constituem religiáo"; ii) as "manifestações religiosas não contêm traços necessários de uma religião, a saber, um texto base (corão, bíblia etc.), estrutura hierárquica e um Deus a ser venerado"; e iii) não há "malferimento de um sistema de fé", posto que, na sua visão, não há colidência, mas sim concorrência de alguns direitos fundamentais. ${ }^{23} \mathrm{Em}$ tempo, cumpre mencionar que as religióes de matriz africana são consideradas comunidades tradicionais, ${ }^{24}$ portanto compartilham de valores civilizatórios e de uma cosmovisão a partir da tradição trazida de países do continente africano. Entendidas como patrimônio cultural legado pelo povo negro escravizado, as práticas religiosas com ancestralidade africana ao longo dos séculos no Brasil estiveram em posição de subalternidade ou sub-representação em relação a outras manifestaçóes religiosas. $\mathrm{O}$ direito à crença, apesar de estar resguardado em diversos estatutos legais, mostra como essa faceta do racismo perpetua uma historiografia que associa os valores civilizatórios africanos a práticas rudimentares.

Apesar de o magistrado posteriormente retificar sua decisão, reconhecendo as religiôes de matriz africana como religióes propriamente ditas, ele manteve inalterada a decisão no que se refere à permanência de vídeos que promovem manifestamente a intolerância religiosa. $\mathrm{O}$ juiz fundamentou sua decisão no direito a liberdade de expressão, de crença e no direito de reunião. A despeito de todos os instrumentos legais ${ }^{25}$ que protegem o direito a manifestação de fé, a sentença de primeira instância revela traços de como o tema da intolerância religiosa tem sido negligenciado pelo poder judiciário.

A livre manifestação da fé, como um direito inviolável, ${ }^{26}$ tem sido sistematicamente desrespeitada no Brasil, especialmente com as religióes de matriz africana. A incitação à violência, depredação e queima dos templos de umbanda e candomblé, bem como de suas imagens sagradas, tem sido recorrente no cotidiano

23. A este respeito ver (Rio de Janeiro, 2014b).

24. Decreto 6.040/2007, Artigo 3․: "(...) Povos e Comunidades Tradicionais: grupos culturalmente diferenciados e que se reconhecem como tais, que possuem formas próprias de organização social, que ocupam e usam territórios e recursos naturais como condição para sua reprodução cultural, social, religiosa, ancestral e econômica, utilizando conhecimentos, inovações e práticas gerados e transmitidos pela tradição" (Brasil, 2007b).

25. Artigo 5, inciso Vl; Artigo 19, I, da CF/88; Artigo 24; Artigo 26, do Estatuto da Igualdade Racial (Brasil, 2010a); Artigo 209, Código Penal (Artigo 209); Lei 9.459, de 1997; Pacto Internacional Sobre os Direitos Civis e Políticos (PIDCP) adotado e aberto à assinatura, ratificação e adesão pela Assembleia Geral na sua Resolução 2200ミ (XXI) de 16 de dezembro de 1966; Pacto de São José da Costa Rica (Convenção Americana de Direitos Humanos), ratificado pelo Brasil em 25 de abril de 1992.

26. Artigo 5o, VI, da CF/88: "é inviolável a liberdade de consciência e de crença, sendo assegurado o livre exercício dos cultos religiosos e garantida, na forma da lei, a proteção aos locais de culto e a suas liturgias" (Brasil, 1988). 
das pessoas que professam sua religiosidade. Na Secretaria de Direitos Humanos da Presidência da República (SDH) houve um salto no número de denúncias de intolerância religiosa, que saiu de 109 em 2012, para 149 em 2014. A própria SDH reconhece que estes dados estáo subestimados, levando em consideração diversos fatores como a ausência de um canal específico para as denúncias, que podem ser feitas diretamente nas delegacias, em órgão estaduais e municipais de proteção aos direitos humanos. Essas informaçóes não estáo centralizadas em uma única instância de modo a conseguir criar um panorama nacional sobre esse tema.

O ano de 2013 foi o primeiro de funcionamento do I Plano Nacional de Desenvolvimento Sustentável dos Povos e Comunidades Tradicionais de Matriz Africana, ${ }^{27}$ cujo vigência vai até 2015. Esse plano foi elaborado por um grupo de trabalho interministerial, instituído pela Portaria no 138/2012 da Seppir. A elaboração desse primeiro Plano representa a concretização do Decreto no 6.040/2007, que instituiu a Política Nacional de Desenvolvimento Sustentável dos Povos e Comunidades Tradicionais (Brasil, 2007b). O plano é dividido em três eixos, quais sejam: i) garantia de direitos; ii) territorialidade e cultura; e iii) inclusão social e desenvolvimento sustentável. No eixo 2), localizam-se as açóes previstas para as religióes de matriz africana, sendo delineados três objetivos: $i$ ) mapear os povos e comunidades tradicionais de matriz africana; ii) promover a regularização fundiária e a institucionalização dos espaços necessários à manutenção das tradiçôes de matriz africana; e iii) promover, preservar e difundir o patrimônio e as expressóes culturais dos povos e comunidades tradicionais de matriz africana.

No que tange à temática da intolerância religiosa, a responsabilidade pela implementaçáo desse plano é da Secretaria de Políticas para Comunidades Tradicionais (Secomt), que tem atribuição para elaborar e monitorar as políticas desenvolvidas. Segundo o relatório de gestão da Seppir de $2013,{ }^{28}$ para o cumprimento do plano, foram realizadas as seguintes atividades:

- realizaçáo de duas oficinas de SICONV (em janeiro de 2013 e março 2013);

- realização da Plenária do povos e comunidades tradicionais com 160 lideranças dos 27 estados e DF (julho de 2013);

- desenvolvimento do programa de segurança alimentar que em 2013 distribuiu 92.490 cestas básicas para comunidades de terreiro, beneficiando 17.200 famílias; e

- estabelecimento de dois acordos de cooperação:

27. Disponivel em <http://goo.gl/hRkHNV>.

28. Informações em Seppir (2013). 
a) Brasil-Espanha ${ }^{29}$ (continuidade de acordo anterior, que possibilitou em 2013 os subsídios necessários para continuidade do programa de segurança alimentar e desenvolvimento de estudos); e

b) Seppir-PNUD, que destina $\mathrm{R} \$ 5.526 .650,15$ a a apoio ao Desenvolvimento Sustentável dos Povos e Comunidades Tradicionais para a execução entre 2013-2015.

O que se percebe é que, apesar de 2013 ter sido o primeiro ano de implementação do Plano, pouco se tem feito para atingir as metas previstas. Entre as iniciativas propostas cumpre mencionar a previsão de realização de campanhas e produção de material que valorizem e promovam a não discriminação para com as comunidades tradicionais. A concretização das iniciativas previstas torna-se central na temática do enfrentamento à intolerância religiosa. A invisibilização histórica em relação a esta pauta tem significado a permissão, ainda que silente, da violência contra as religióes de matriz africana. Neste sentido, a educação, como fator de formaçáo de identidades socioculturais, se torna essencial para impulsionar a cultura da alteridade e do respeito mútuo.

\subsection{Eleições 2014 e dados por cor ou raça}

Em resposta a demandas sociais, pela primeira vez, o Tribunal Superior Eleitoral (TSE) passou a coletar informaçóes sobre a cor ou raça dos candidatos às eleiçóes. Em 2014, foram disputados os cargos de presidente da república, senador, deputado federal, governador e deputado estadual e distrital. Do conjunto de mais de 22 mil candidatos, $43,7 \%$ eram negros, percentual significativo, mas ainda abaixo da participação de pretos e pardos na composição nacional. Segundo a PNAD (2012), negros correspondem a 53\% da populaçâo. Neste caso, dos 32 partidos que concorrem às eleições de 2014, apenas cinco apresentaram igual ou maior percentual de negros entre seus candidatos, em geral, partidos com menor representação. ${ }^{30}$ Em seguida, outros quatro possuíam mais de $50 \%$ de candidatos negros. ${ }^{31} \mathrm{O}$ partido com menor participação de negros entre as candidaturas apresentadas foi o PMDB (27,2\%), seguido pelo PTB (31,8\%), PSDB (32,6\%), PSD (33,3\%) e PP (34,5\%).

O Acre foi o único estado em que a participação de negros entre os candidatos foi superior à sua participação na população (negros correspondiam a 70,6\% da populaçấo e $80,6 \%$ dos candidatos). A maior desigualdade entre participação na populaçáo e percentual de candidaturas foi encontrada na região sul. Nesta região, os estados apresentam menor coeficiente entre as participaçóes percentuais de

29. "Cooperação Técnica Brasil-Espanha de Combate ao Racismo e Promoção da Igualdade Racial" Seppir e a Agência Espanhola de Cooperação Internacional para o Desenvolvimento (AECID).

30. PCB, PCdoB, PCO, PTN; e PSOL.

31. PMN, PPL, PSL; e PSDC. 
candidaturas negras e percentuais de negros na população. No Rio Grande do Sul, Paraná e Santa Catarina, o percentual de candidaturas negras correspondeu, respectivamente, a $43,1 \%, 57 \%$ e $55 \%$ da participação de negros na populaçáo total. ${ }^{32}$

A participação de candidaturas negras não se altera muito nas diferentes faixas etárias. Entre candidato em faixas de 18 a 59 anos, variou de $43,4 \%$ a $46,5 \%$ do total das candidaturas. Na faixa de mais de 60 anos, a participaçáo negra foi inferior à média (36,3\%). Em relação à escolaridade, cabe destacar que $46,9 \%$ dos candidatos têm ensino superior completo e apenas 35,2\% destes são negros. Se a maior parte dos parlamentares eleitos tem ensino superior, a população negra está ainda em maior desvantagem na faixa de escolaridade mais competitiva. Ademais, uma vez que a renovação do Congresso Nacional costuma ser inferior à metade das cadeiras, a competição para os grupos historicamente alijados desses espaços é ainda maior. ${ }^{33}$

Análise realizada por Campos e Machado (2014) e Campos (2014b) não reforça pretensa clivagem esquerda/direita como viés de maior participação de candidatos negros. Os autores destacam que há partidos cuja composiçáo racial das listas de candidaturas difere muito entre os níveis estadual e federal. Partidos com maior representação branca no nível federal apresentam graus diferentes de participaçáo no nível estadual, o que robustece a avaliação de que a hierarquia dos cargos aumenta a barreira de entrada.

A tabela 1 apresenta dados sobre candidaturas e resultados por cargo, de acordo com o quesito cor ou raça. Pode-se verificar que a participaçáo de candidatos negros diminui com a importância hierárquica do cargo. Enquanto para presidência apenas uma candidata é negra, entre candidatos a governador e senador, os negros representam cerca de $30 \%$ dos candidatos; por sua vez, a participação se eleva para candidatos a deputados, com maior participação para os estaduais e distritais. Sob outro prisma, pode-se verificar que a presença de candidatos negros é menor nos cargos majoritários, mais disputados nos partidos, do que nos proporcionais. Nestes, ainda que os candidatos negros não sejam exitosos, sua participaçáo pode captar votos para a legenda.

Neste cenário, as condiçôes de gênero e raça mais uma vez impelem as mulheres negras para o fim da fila. Como destaca estudo do Inesc (2014, p. 3), as mulheres negras são aquelas menos representadas nas candidaturas, com apenas $14,2 \%$ das candidaturas, seguidas pelas mulheres brancas, com 16,5\%, homens negros, com $30 \%$, e homens brancos, com $38,6 \%$.

32. RS, PR e SC: participação de negros na população total conforme PNAD 2012 (19,4\%; 29,9\%; 15,2\% respectivamente) e participação de negros no total de candidaturas $(8,4 \%, 17,1 \%, 8,4 \%$ respectivamente).

33. Segundo a Diap (2010, p. 15), na bancada eleita na Câmara Federal em 2010, "pelo menos 444 deputados ingressaram num curso superior e quatrocentos deles concluíram a graduação. $47(9,1 \%)$ cursaram o ensino médio e 22 (4,2\%), o fundamental. A julgar pelo grau de instrução, a Câmara estará entre as de maior escolaridade no mundo". Com taxas de renovação de Câmara - 43,86\% - e Senado - 45,68\% - (p. 21). 
TABELA 1

Candidatos e eleitos por cor ou raça (2014)

\begin{tabular}{|c|c|c|c|c|c|c|c|c|}
\hline \multirow{2}{*}{ Cargo/cor ou raça } & \multicolumn{4}{|c|}{ Candidaturas (\%) } & \multicolumn{4}{|c|}{ Eleitos (\%) } \\
\hline & Amarela & Branca & Indígena & Negra & Amarela & Branca & Indígena & Negra \\
\hline Presidente & - & 90,9 & - & 9,1 & - & 100,0 & - & - \\
\hline Governador & 0,5 & 69,1 & - & 30,4 & 3,7 & 74,1 & - & 22,2 \\
\hline Senador & - & 69,2 & 1,7 & 29,1 & - & 81,5 & - & 18,5 \\
\hline Deputado Federal & 0,6 & 59,2 & 0,4 & 39,9 & - & 79,9 & - & 20,1 \\
\hline Deputado Estadual/Distrital & 0,4 & 53,6 & 0,3 & 45,6 & 0,2 & 73,3 & 0,2 & 26,3 \\
\hline Total & 0,5 & 55,4 & 0,4 & 43,7 & 0,2 & 75,5 & 0,1 & 24,2 \\
\hline
\end{tabular}

Fonte: TSE/Repositórios de dados eleitorais - Candidatos 2014 (exclusive suplentes).

Elaboração: Disoc/lpea.

Para além dos dados das candidaturas, é importante analisar o potencial de êxito eleitoral dos aspirantes ao parlamento e ao executivo. Como destaca Campos (2014b), a eleição de candidatos negros está relacionada não apenas com a escolha dos eleitores, mas também com viés de recrutamento partidário das candidaturas. Conforme levantamento realizado pela Unegro (2011), apenas 43 negros foram eleitos deputados federais em 2010, 8,3\% da bancada (dentre os quais, apenas sete mulheres).$^{34}$ Destarte, como citado, as candidaturas negras são mais frequentes em partidos menores, ${ }^{35}$ com menor potencial eleitoral. Com efeito, há partidos com maiores chances eleitorais que recrutam seus candidatos em estratos mais altos da sociedade, onde a população negra ainda é minoritária (Campos, 2014). Mesmo em partidos mais competitivos, nem sempre negros e mulheres recebem efetivo apoio para suas campanhas, tendo que enfrentar os efeitos do racismo e discriminação dentro e fora de suas agremiaçóes. No caso das mulheres, em que há cota legal, ${ }^{36} \mathrm{o}$ dilema entre as candidaturas e êxito eleitoral é claro. O número de candidaturas de mulheres subiu de $22,4 \%$ nas eleiçôes de 2010 para 30,8\% nas eleições de 2014. No entanto, nas eleiçóes de 2010, elas alcançaram apenas 8,8\% das vagas na Câmara dos Deputados e 14,8\% no Senado (Inesc, 2014, p. 16). Ainda que o resultado tenha sido melhor nas eleiçóes de 2014, com efeito, não foi muito diferente: 9,9\% de mulheres na Câmara e 18,5\% no Senado (Zigoni, 2014).

34. Na ausência de dados oficiais sobre a cor ou raça dos parlamentares, a pesquisa desenvolvida pela Unegro utilizou como método de classificação a consulta direta a parlamentares, a suas assessorias ou a documentos dos mandatos que registrassem a declaração racial dos políticos. As informações sobre a metodologia foram colhidas, de forma mais detalhada, em contato telefônico com o Sr. Alexandre Braga, da coordenação geral da pesquisa, em 18 set. 2014.

35. Estudo realizado por Campos (2014b) analisa candidaturas de vereadores em Rio de Janeiro e São Paulo nas eleições de 2012 e identifica que nos partidos menores, segundo número de filiados, havia maior participação de negros. A classificação racial, nesta pesquisa, foi feita por heteroclassificação, com uso de fotografias.

36. Cotas para candidaturas negras é o objeto da PEC no 116/2011, que determina "reserva de vagas na Câmara dos Deputados, nas assembleias legislativas e na Câmara Legislativa, por cinco legislaturas, para parlamentares oriundos da população negra". 0 tema também foi item descartado durante a tramitação do Estatuto da Igualdade Racial (Silva, 2012). 
Os dados dos eleitos (tabela 1) mostram que a chance eleitoral dos negros é muito menor. A participaçáo dos negros se reduz de 30\% a 50\% entre os eleitos, se comparados com as candidaturas com o mesmo perfil racial. A participação de negros entre os eleitos em 2014 é superior aos dados das eleiçóes de 2010, apresentados pelo estudo na Unegro, citado anteriormente. Todavia, convém salientar que os dados de cor ou raça foram coletados por metodologias diferentes, o que contraindica comparaçáo mais linear e menos cuidadosa. O que pode ser inferido é a existência e a persistência da alta sub-representaçáo da populaçáo negra nos parlamentos nas duas últimas bancadas eleitas.

A disponibilidade de dados sobre cor ou raça dos candidatos remete a outro ponto fundamental no que tange às eleiçôes: embora o aumento da participação da população negra nos cargos políticos seja muito importante, não é suficiente para que a questão racial conquiste mais espaço nos parlamentos e na formulação e execução das políticas públicas. Se a maior participação de negros nesse campo é direito de parte majoritária da população, considerar, em sua atuação política, o racismo e seus efeitos - parte estruturante das desigualdades sociais -, é dever dos representantes políticos, qualquer que seja sua cor ou sua raça.

No estudo da Unegro aponta-se que, dos 27 partidos políticos registrados no TSE em 2010, apenas nove dispunham de "secretarias dedicadas aos negros ou de setorial afro" (Unegro, 2011, p. 3). ${ }^{37}$ Além da Frente Negra no Congresso nacional, apenas quatro estados (MG, BA, SP e AP) e dois municípios (Salvador e Belo Horizonte) dispunham de instância similar em suas casas legislativas.

O tema do enfrentamento ao racismo ainda carece, pois, de força nas plataformas eleitorais e, consequentemente, nos programas de governo. Levantamento realizado pelo Laboratório de Análises Econômicas, Históricas, Sociais e Estatísticas das relaçôes Raciais (Laeser) analisou os planos de governo dos onze candidatos à Presidência da República ${ }^{38}$ (Laeser, 2014). Por um lado, foram identificadas lacunas significativas em temas relacionados à pauta racial, como saúde da população negra e intolerância religiosa, inclusive nas candidaturas mais bem colocadas pelas pesquisas de intenção de voto. Por outro lado, temas antes considerados polêmicos e conflitivos, como as políticas afirmativas e as cotas, receberam aprovação das principais candidaturas. ${ }^{39}$ Para algumas candidaturas, no entanto, o tema racial não foi sequer mencionado.

37. São eles: PHS, PT, PMDB, PDT, PTB, PRB, PSTU, PCO, PSDB (Unegro, 2011, p. 3).

38. Atualizados até $31 /$ jul./2014.

39. Segundo o estudo, somente o PCO tratou do tema saúde da população negra e nenhuma candidatura tratou de intolerância religiosa. Por sua vez, PSDB, PT, PSTU e PSB trataram das políticas de ação afirmativa, afirmando a continuidade das medidas. 
Cabe anotar que os dados de classificação racial tendem a dar visibilidade às trajetórias de negros e negras na política e na sociedade, caminho marcado por lutas e conquistas nos passos de nomes como Minervino Oliveira, Antonieta de Barros e Abdias do Nascimento. ${ }^{40}$

A expectativa agora é que os dados disponibilizados pelo TSE permitam a realização de investigaçôes mais aprofundadas. Em uma primeira mirada, os dados mostram a cor e a raça dos candidatos, mas não desvendam os mecanismos de discriminação promovidos pelo racismo e pelo machismo, desde o recrutamento das candidaturas até a escolha dos eleitores. Investigar e explicitar esses instrumentos de reprodução das desigualdades pode permitir náo apenas enfrentá-los diretamente, como também contribuir com a reflexâo de que mudanças são necessárias para que o sistema político consiga melhor representar a sociedade brasileira.

\subsection{Conferência nacional de promoção da igualdade racial}

A III Conferência Nacional de Promoção da Igualdade Racial (Conapir), ocorrida entre 5 e 7 de novembro de 2013, foi realizada em meio aos dez anos de criação da Secretaria de Políticas de Promoçâo da Igualdade Racial (Seppir). Com o tema central $A$ democracia e desenvolvimento sem racismo: por um Brasil afirmativo, esta conferência reafirmou os compromissos do Governo com a efetivação da referida política e com o fortalecimento institucional da questão racial na agenda do Estado brasileiro.

A concretização de três conferências até então contribuiu para que a pauta racial passasse a compor um espaço importante de proposiçóes e deliberaçôes de representação política, no âmbito das açôes de governo, em diálogo permanente com a sociedade civil. As mediaçóes políticas decorrentes dessa fruição participativa sinalizam a intenção de fortalecimento e aprofundamento do processo democrático brasileiro, promovendo uma nova dinâmica para as políticas de enfrentamento ao racismo.

Com efeito, os esforços decorrentes dessa inserção temática na agenda governamental têm demandado ampliação da capacidade de diálogo entre as diversas instâncias intersetoriais e entre o governo e as representaçôes da sociedade civil. Neste sentido, a criação da Seppir representou uma inovação institucional que requer continuadamente dos órgãos e instituições permeabilidade para assimilar o caráter específico dessa política que busca articular participação na política universalista e focalizaçáo no enfrentamento ao racismo institucionalizado.

40. Minervino Oliveira, o primeiro homem negro candidato ao posto mais alto do executivo, pelo PCdoB, em 1930 Antonieta de Barros, eleita deputada estadual em Santa Catarina, em 1934. Abdias do Nascimento, referência do movimento negro brasileiro, foi deputado federal e primeiro senador negro em 1991. 
No entanto, a questáo central para a consolidação da referida temática tem sido articular essa agenda ao conjunto das demais políticas. Se no âmbito interno de governo esses fatores são determinantes para uma maior sinergia interministerial, na relação com a sociedade civil a fragmentação das políticas sugere uma dificuldade ainda maior de aliar as açóes e programas de governo com as expectativas expressas em um conjunto de propostas surgidas no interior dos diversos segmentos organizados da população negra.

Por outro lado, a quase inexistência de avaliação dos processos ocorridos das conferências anteriores sinalizam uma descontinuidade das açóes, promovendo uma sensação de recomeço, o que em síntese dificulta o acompanhamento e controle social das açóes de governo.

Todas as conferências (políticas de promoção de igualdade racial) foram realizadas após a elaboração do Plano Plurianual do governo federal, que estipula as açôes e orçamentos a serem desenvolvidos nos quatro anos seguintes. Deste modo, as deliberaçóes advindas desse fórum teriam dificuldades adicionais a serem inseridas no planejamento governamental, além daquelas inerentes à própria política e aos limites da burocracia.

Por sua vez, diferentemente de outras áreas, não foi possível a esta área compor um Plano Nacional para a política que envolvesse atores sociais e governamentais na elaboração de metas e definição de recursos. O único Plano Nacional elaborado ao longo de dez anos e três conferências limita-se a elencar deliberaçóes para a área, com enunciados de níveis macro a operacional, sem explicitar os elementos mínimos, como os citados, que pudessem oferecer possibilidade de acompanhamento sistemático de sua evolução.

A despeito destas limitaçóes, o desenvolvimento da Conapir, em suas três versóes, permitiu acompanhar, por sua vez, a trajetória de construçáo desse espaço de promoção da equidade política, que se traduz nas intençôes e repertórios marcados pelos temas centrais de cada uma delas. Na I Conapir, o tema central - Estado e Sociedade Promovendo a Igualdade Racial - sedimentou a inserção da questão racial nos processos participativos de políticas governamentais, a partir da tentativa de construção do Plano Nacional de Promoção da Igualdade racial.

Em seguida, a II Conapir, ao apresentar como tema central os Avanços, desafios e perspectivas da Politica Nacional de Promoção da Igualdade Racial, reafirmou a instalação do tema entre os compromissos do governo federal, e procurou avaliar os avanços e impasses para a consecução da referida política. Nesse contexto, o discurso que embasou a conferência dava ênfase à adoçáo de mecanismos de gestão que garantissem a efetividade da política, a exemplo do debate em torno 
da institucionalização da política com vistas à implantação do Sistema Nacional de Promoção da Igualdade Racial (Sinapir). ${ }^{41}$

Por fim, a III Conapir ocorreu em um momento bastante favorável, em que se verifica a ampliação do debate em torno da questão racial, bem como os avanços no arcabouço institucional que trata da promoção da igualdade racial, especialmente no que se refere às políticas de ação afirmativa. Nesse contexto, o discurso de referência da conferência trazia a reflexáo sobre como as desigualdades sociais e econômicas em conjunção com o racismo se apresentam como um entrave ao desenvolvimento.

A III Conapir inovou ao organizar plenárias temáticas, com o objetivo de ampliar a participaçáo de determinados grupos nas conferências, desde o nível municipal. Desta forma, ciganos, quilombolas e praticantes de religióes de matriz africana tiveram participação privilegiada. ${ }^{42}$

Essa conferência última sinalizou uma mudança no processo de mobilização e estruturaçấo do seu formato, ao adotar um sistema de monitoramento, ainda que em fase experimental, criando mecanismos que possibilitassem uma melhor institucionalidade do processo participativo.

Entretanto, é interessante ressaltar que as discussóes mais gerais nas conferências sinalizam para um modelo de participação em que não se percebe a intenção de formular soluçóes especificas para as áreas temáticas. Nesse sentido, parece ficar distante a percepção de uma visão sistêmica em torno da consolidação de um Plano Nacional de Promoção da Igualdade Racial.

$\mathrm{Na}$ abertura da terceira Conapir, a Presidente da República, Dilma Rousseff, cumpriu um importante ato simbólico ao anunciar entregas relevantes para a população negra. A que ganhou mais destaque foi, sem dúvida, o anúncio do envio ao Congresso Nacional de Projeto de Lei (PL) que instituía cotas de 20\% para negros em concursos públicos. Os desdobramentos desse PL serão tratados na seção 3.2.1.

Na ocasiāo, a presidenta também assinou o Decreto no 8.136/2013, que regulamenta o Sistema Nacional de Promoção da Igualdade Racial (SINAPIR),

41. Em 2010, com a instituição do Estatuto da Igualdade Racial a partir da Lei o 12.288 (20 de julho de 2010), em seu Título III (Cap. I, II e III), prevê a criação do Sinapir, que tem como objetivo promover a gestão da Política de Promoção da Igualdade Racial, de forma descentralizada e participativa. Operando na consolidação do modelo de gestão compartilhada, o cofinanciamento e a cooperação técnica entre os três entes federativos, que de modo articulado e complementar deverá atender as demandas na promoção da igualdade racial bem como no combate as desigualdades sócio raciais, mediante ações afirmativas e o enfrentamento do racismo. Devendo ainda, participar da organização, do desenvolvimento, da avaliação e do monitoramento dos processos de formulação de políticas públicas, de forma que a perspectiva da igualdade racial seja incorporada em todas as políticas de Governo, em todos os seus níveis e em todas as suas fases. 42. No processo anterior à realização da terceira Conapir, ocorrem as três plenárias nacionais especificas: Comunidades Tradicionais, Comunidades de matrizes africanas e Comunidades ciganas. 
o que representou um passo significativo para normatizar as ações integradas da política de promoção da igualdade racial, nos três níveis federativos.

No entanto, cabe analisar em que dimensão essa articulação e integração de açóes no âmbito federal, estadual e municipal, dentro de uma perspectiva sistêmica, podem superar os obstáculos e dificuldades de funcionamento das políticas com características transversais. O desafio da intersetorialidade ainda reside nas limitaçóes institucionais com que alguns organismos de governo operam, a exemplo da Seppir.

Por fim, resta mencionar o terceiro anúncio presidencial, cujos desdobramentos sintetizam parte dos desafios que a política de igualdade racial enfrenta no momento. Trata-se de uma nova instância de articulação técnico-política no âmbito do Ministério da Saúde (MS), para desenvolvimento da Política Nacional de Saúde Integral da População Negra (PNSIPN). ${ }^{43}$

Embora institucionalizada desde 2006, a PNSIPN passa por importantes obstáculos para sua plena implementação, denunciados notadamente pelo Comitê Técnico que assessora o MS no desenvolvimento da política. $\mathrm{O}$ anúncio presidencial sobre uma nova instância no MS criou a expectativa de que o tema voltasse ao gabinete do Ministro, com maiores possibilidades de atuação para implementação da política. Esta era a proposta do Comitê Técnico, que já havia pactuado a criaçáo da Coordenação de Saúde Integral da População Negra (CSIPN), nesses termos. Não obstante a manifestação pública de anúncio de criação desta instância, sua efetivação nos moldes defendidos pelo Comitê Técnico não prosperou, estando ainda em apreciação do Ministério do Planejamento, desde março de 2014.

A discrepância entre o discurso e a ação, entre o arcabouço legal e a prática nas organizaçóes e na operação das políticas públicas, permeada pelo racismo institucional e pelo lugar que a ação de promoção da igualdade racial ocupa no imaginário social ilustram bem o desafio para institucionalização das políticas de combate ao racismo e promoção da igualdade racial, inclusive na sua via de participação social.

43. A Política Nacional de Saúde Integral da População Negra (PNSIPN), aprovada pelo Conselho Nacional de saúde (CNS), em 2006, e oficializada pelo Ministério da Saúde (MS), em 2009, por meio da Portaria no 992/09, e inserida na Lei no 12.288/2010 (Estatuto da Igualdade Racial), estabelece a efetivação de procedimentos necessários ao reconhecimento do racismo institucional como determinantes sociais das condições de saúde, com vistas à promoção da equidade em saúde. A partir deste marco, foram construídos diferentes instrumentos de gestão para a consolidação dessa política: em 2011, o Ministério da Saúde firmou com a Seppir, um protocolo de intenções para a implementação de um programa de combate ao racismo institucional do Ministério da Saúde e do Sistema Único de Saúde e a institucionalização de uma estratégia para a implementação da Política Nacional de Saúde Integral da População Negra. 


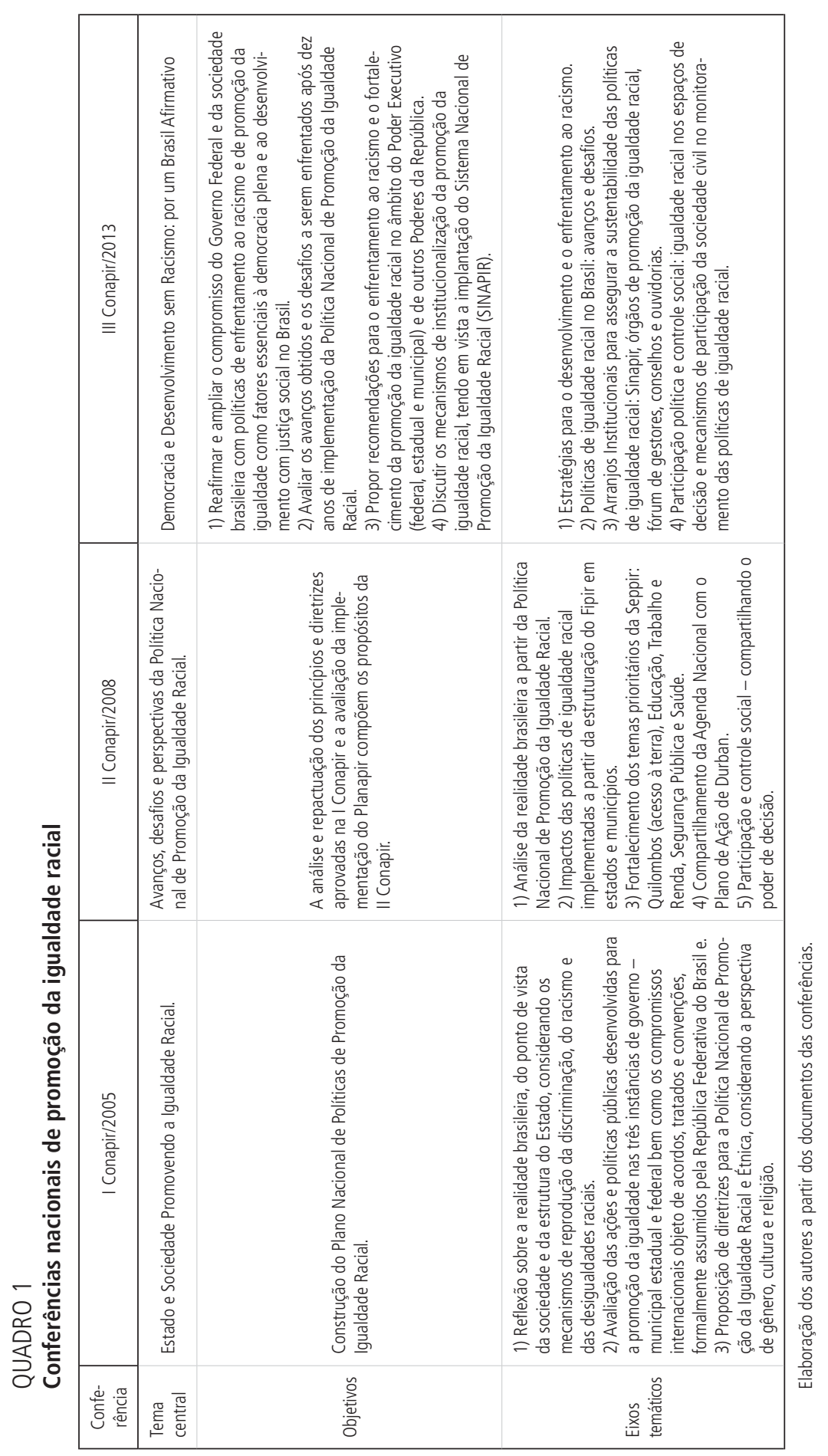




\section{ACOMPANHAMENTO DA POLÍTICA E DOS PROGRAMAS}

\subsection{Ações afirmativas no ensino superior no Brasil}

As políticas de ações afirmativas (AA) no ensino superior no Brasil vêm se consolidando ao longo da última década. Essas ações vão desde políticas de ingresso em Instituição de Ensino Superior (IES) a políticas de permanência estudantil, fomento à pesquisa, prioridade no acesso a financiamento e políticas que visem corrigir distorções históricas, entre outras.

Açóes afirmativas, como medidas redistributivas, cumprem o papel de beneficiar determinados grupos sociais desfavorecidos, ampliando a oportunidade de acesso destes em diversas esferas, seja econômica, política, cultural, social. O retrato das desigualdades atualmente vividas no Brasil é marcado por uma profunda desigualdade racial, que coloca a população negra em situação de maior vulnerabilidade. ${ }^{44}$

Ao longo dos últimos anos, as AAs de ingresso no ensino superior foram progressivamente se estabelecendo em IES públicas e se consolidando na jurisprudência brasileira, culminando com a declaração de constitucionalidade do sistema de cotas para negros da Universidade de Brasília (UnB), proclamada pelo Supremo Tribunal Federal (STF) em abril de $2012^{45}$ e a aprovação da Lei no $12.711 / 2012$, que institui cotas em Instituiçóes Federais de Ensino Superior (Ifes).

Até 2012 não existia uma política nacional de ação afirmativa no ensino superior. Até aquele momento, algumas IES públicas haviam criado açóes afirmativas de ingresso no Ensino Superior, de forma independente. Seja por meio de resoluções fruto da autonomia universitária, seja por meio de legislação estadual, o fato é que, a partir das IES, as ações afirmativas (ou o seu debate) passaram a estar presentes em diversos setores da sociedade brasileira. Era este o panorama das ações afirmativas nas IES, até 2012 (tabela 2).

TABELA 2

IES públicas e ações afirmativas até 2012

\begin{tabular}{|c|c|c|c|c|}
\hline Nível & IES públicas & Total & IES com AA & $(\%)$ \\
\hline \multirow{3}{*}{ Federal } & Universidades federais & 59 & 49 & 83,0 \\
\hline & Institutos federais & 40 & 33 & 82,5 \\
\hline & Faculdade federal & 4 & - & - \\
\hline \multirow[b]{2}{*}{ Estadual } & Universidades estaduais & 38 & 34 & 89,4 \\
\hline & $\begin{array}{l}\text { Faculdades estaduais (faculdades, escolas universitárias, fundações e } \\
\text { instituto estadual) }\end{array}$ & 77 & 14 & 18,2 \\
\hline
\end{tabular}

44. Ver Ipea (2011)

45. O STF declarou constitucional a política de cotas para negros adotada na UnB ao ser provocado judicialmente pelo Partido Democratas na Ação de Declaração de Descumprimento de Preceito Fundamental no 186. 


\begin{tabular}{|c|c|c|c|c|}
\hline Nível & IES públicas & Total & IES com AA & $(\%)$ \\
\hline & Centros universitários & 10 & 3 & 30,0 \\
\hline \multirow[t]{2}{*}{ Municipal } & Faculdades municipais & 65 & 1 & 1,5 \\
\hline & Universidades municipais & 11 & - & - \\
\hline Total & & 304 & 134 & 44,0 \\
\hline
\end{tabular}

A partir dos dados apresentados, percebe-se que 44,0\% das IES, até 2012, adotaram algum tipo de AA, com maior participação de Ifes e universidades estaduais. Das 134 IES que apresentaram algum tipo de ação afirmativa, apenas 51 faziam um recorte racial. Isso significa que apenas $17 \%$ do total de IES públicas no Brasil faziam um recorte racial nas políticas afirmativas que desenvolviam.

Apesar de ser uma pauta apresentada e defendida inicialmente pelos movimentos sociais negros, as açóes afirmativas em IES acabaram contemplando um público bastante heterogêneo, com preponderância das açôes afirmativas para estudantes de escola pública.

No quadro abaixo foram consideradas todas as especificidades das AA identificadas, com base em levantamento do INCTI/UnB (Carvalho, 2012). A apresentação dos dados obedece à seguinte lógica: se uma instituição promove açóes afirmativas voltadas para estudantes de escola pública e para indígenas, essas açôes foram registradas nas duas modalidades. Dessa forma, a percepção de como os diversos sujeitos estavam contemplados nas políticas cotas existente até 2012 fica mais visível.

TABELA 3

Mapa de ações afirmativas em IES públicas por público contemplado

\begin{tabular}{lcccccc}
\hline IES/região & Norte & Nordeste & Centro-Oeste & Sul & Sudeste & Total \\
\hline Total de IES públicas & 28 & 65 & 19 & 49 & 143 & $\mathbf{3 0 4}$ \\
\hline Com AA & 17 & 37 & 13 & 33 & 34 & $\mathbf{1 3 4}$ \\
\hline & Número de IES & por tipo de AA & & & & \\
\hline Escola pública & 7 & 33 & 13 & 24 & 32 & 109 \\
Indígenas & 11 & 14 & 9 & 21 & 13 & $\mathbf{6 8}$ \\
Negros(as) & 3 & 14 & 7 & 12 & 16 & $\mathbf{5 2}$ \\
Deficiente físico & 7 & 6 & 3 & 7 & 9 & 32 \\
Moradores(as) de determinadas das regiões & 3 & 5 & 3 & 16 & - & $\mathbf{2 7}$ \\
Baixa renda & - & 3 & 1 & 2 & 9 & $\mathbf{1 5}$ \\
Quilombolas & 1 & 4 & 2 & - & - & $\mathbf{7}$ \\
Filhos de policiais militares & - & - & - & - & 4 & 4 \\
Agricultores (ou filho/a) e assentado(a) & 1 & 1 & 1 & - & 1 & 4 \\
Professores e servidores públicos & - & 2 & - & - & - & $\mathbf{2}$ \\
Mulheres & 1 & 1 & - & - & - & $\mathbf{2}$ \\
Refugiados políticos & - & - & - & - & 1 & $\mathbf{1}$ \\
\hline
\end{tabular}

Fonte: Mapeamento INCTI/UnB (2012). Elaboração dos autores. 
Como se pode observar a partir do quadro apresentado, as AAs de ingresso em IES públicas no Brasil assumiram um caráter bem heterogêneo. A maioria agregava dois ou mais critérios para o público beneficiado (56\%). Existem medidas somente para estudantes de escola pública (29\%), sem a necessidade de outro requisito, como ser negro ou ter determinada renda. Assim como existem medidas somente para estudantes negros (AA raciais), representando 5\% (07 IES), número bem reduzido em relação àquelas destinadas exclusivamente a estudantes de escolas públicas. O que se observa é que o critério socioeconômico, especialmente de escola pública, se destaca entre os condicionantes para ter acesso à AA.

O caráter plural das AAs também pode ser observado nas diferentes regióes do país. Apesar de dispor de um panorama nacional das medidas afirmativas, perceber as especificidades regionais torna-se uma condiçáo sine qua non para entender os diferentes sujeitos contemplados, bem como o impacto das AAs.

\subsubsection{Análise regional}

As açôes afirmativas desenvolvidas na região Norte do Brasil têm uma forte presença de medidas para a inclusão de populações indígenas. Das 17 IES que têm açōes afirmativas, $65 \%$ têm um recorte para a população indígena. Essa região é também onde houve a menor presença de AAs com recorte racial para a população negra (17\%).

Em relação à região Nordeste, o que se observa das políticas de açóes afirmativas adotadas (até 2012) é que a maioria optou por ação afirmativa com critério socioeconômico (89\%), ou seja, destinação de vagas a estudantes de escolas públicas, combinada ou não com outros critérios. Nenhuma universidade adotou cotas exclusivamente raciais, sendo que AAs com critério racial representam apenas 38\% nesta regiáo.

Na região Centro-Oeste todas as IES públicas que adotaram AAs incluíram o critério de escola pública, isoladamente ou combinando com dois ou mais critérios. É a região que, proporcionalmente, adotou o maior número de ações afirmativas, sendo que, do total de IES públicas, $68 \%$ adotaram algum tipo de AA de ingresso no ensino superior. É também nessa regiáo onde o recorte racial encontrava o maior percentual, sendo que 54\% das AAs têm um recorte para a população negra.

A regiáo Sudeste é onde se concentra o maior número de IES no Brasil (143), representando $47 \%$ de todas as Instituiçóes. Apesar de ter inaugurado a adoção de AAs em IES, a região é onde, proporcionalmente, houve a menor adesão por parte das Instituiçóes Públicas. Apenas $23 \%$ das IES públicas do Sudeste adotaram alguma política afirmativa de inclusão. Esse percentual fica muito abaixo da $2^{\mathrm{a}}$ regiâo com menor adesão de AAs, o Nordeste, com 57\% até 2012.

No Sudeste, o critério socioeconômico foi a principal característica das AAs adotadas, tendo em vista que $94 \%$ das IES optaram pelo critério "egresso de escola 
pública" como política inclusiva. No que tange à pauta da populaçáo negra, cerca de $47 \%$ das IES fizeram algum recorte racial, sendo que somente as IES fluminenses incluíram o critério racial isolado de outros critérios. Levando em consideração que 16 IES públicas adotam AAs com recorte racial, esse número representa apenas $11 \%$ das IES de toda a regiáo, percentual equivalente ao encontrado na regiáo Norte (10,7\%).

A região Sul foi a segunda que mais adotou alguma modalidade de AA de ingresso em IES públicas, estando presente em $67 \%$ do total de instituiçóes nela localizadas. É também a segunda na inclusão da temática racial (24\%). Nos dois critérios, fica atrás apenas do Centro-Oeste.

A presença de políticas para indígenas e população negra foi observada em 21 das 33 IES com AA da regiâo Sul. Como as demais regióes do país, açôes afirmativas para estudantes de escolas públicas têm uma forte presença nas IES, identificadas em $72 \%$ das instituiçóes que adotaram AAs.

No que se refere a essas diferenças, percebe-se que, proporcionalmente, a regiáo Centro-Oeste foi a que mais adotou AAs, com $68 \%$ das IES, seguida da região Sul, com 67\%, depois Região Norte, com 60\%, e região Nordeste com 57\%. Por último (e bem distante das demais regióes) estava a regiáo Sudeste, com apenas $23 \%$ de IES que adotaram alguma AA.

\subsubsection{Ações afirmativas e a questão racial}

O cenário das desigualdades de acesso ao ensino superior náo diz respeito apenas à situação socioeconômica, mas ao racismo como fator que estrutura as relaçóes sociais no Brasil. Nesse sentido, o acesso à educação é parte desse contexto e visa garantir maior representação da população negra em todas as etapas de ensino, representando elemento fundamental para o enfrentamento das desigualdades. Senão, vejamos a tabela 4.

TABELA 4

IES públicas e ações afirmativas com recorte racial até 2012

\begin{tabular}{|c|c|c|c|c|c|}
\hline Nível & IES públicas & Total IES & IES com AA & AA com recorte racial & $(\%)$ \\
\hline & Universidades federais & 59 & 49 & 23 & 39,0 \\
\hline \multirow[t]{3}{*}{ Federal } & Institutos federais & 40 & 33 & 5 & 12,5 \\
\hline & Faculdade federal & 4 & - & - & - \\
\hline & Universidades estaduais & 38 & 34 & 17 & 44,7 \\
\hline \multirow[t]{2}{*}{ Estadual } & $\begin{array}{l}\text { Faculdades estaduais (faculdades, escolas } \\
\text { universitárias, fundações e instituto estadual) }\end{array}$ & 77 & 14 & 4 & 0,5 \\
\hline & Centros universitários & 10 & 3 & 2 & 20,0 \\
\hline \multirow[t]{2}{*}{ Municipal } & Faculdades municipais & 65 & 1 & - & - \\
\hline & Universidades municipais & 11 & - & - & - \\
\hline Total & & 304 & 134 & 51 & 16,8 \\
\hline
\end{tabular}

Fonte: Mapeamento INCTI/UnB (2012)

Elaboração dos autores. 
A partir da tabela 4, percebe-se que o recorte racial foi feito em apenas $17 \%$ das IES públicas, o que demonstra que a agenda racial ainda enfrenta dificuldade de efetivação no Brasil. Mesmo nas IES que possuem AA, apenas 38\% destas fazem um recorte racial na política adotada. Percebe-se ainda uma maior presença de medidas com recorte racial em universidades estaduais (45\%) que em instituiçóes federais, especialmente entre os Institutos Federais, onde apenas cinco (de 40) fizeram recorte racial na política adotada.

Com efeito, apesar de o debate público acerca das AAs estar marcado pela discussão racial, ${ }^{46}$ o perfil do público contemplado por estas políticas é diverso, tendo características regionais singulares. O critério racial, ao final, não é o preponderante, apesar de a maior resistência e crítica ao processo de adoçáo das ações afirmativas nas universidades estar relacionada à inclusâo da população negra.

De fato, esse cenário parece ilustrar a persistente recusa em se admitir os efeitos do racismo no país, calcada no mito da democracia racial, que construiu um imaginário social que dificulta o reconhecimento do racismo como estruturante na construção das relaçóes e oportunidades no Brasil.

\subsubsection{Assistência estudantil}

Esse processo de democratização do ensino superior no Brasil tornou ainda mais presente a demanda por políticas de assistência estudantil que já existia em IES, porém com uma presença menor de estudantes de baixa renda. Uma política de assistência eficiente visa corrigir distorção nos índices de evasão e/ou retenção estudantil em IES.

O Plano Nacional de Assistência Estudantil (PNAES) criado em 2007, por meio da Portaria normativa número 39, de 12 de dezembro de 2007, se tornou política de Estado em 2010. ${ }^{47}$ Seu objetivo é

diminuir as desigualdades sociais promovendo a inclusão social de alunos prioritariamente da rede pública de educaçáo básica ou com renda familiar per capita de até um salário mínimo e meio nas Universidades Federais (Brasil, 2010b).

O PNAES tem como eixo de atuação as seguintes áreas: $i$ ) moradia estudantil; ii) alimentação; iii) transporte; iv) atenção à saúde; $v$ ) inclusão digital; vi) cultura; vii) esporte; viii) creche; $i x$ ) apoio pedagógico; e $x$ ) acesso, participação e aprendizagem de estudantes com deficiência, transtornos globais do desenvolvimento e altas habilidades e superdotação.

Nesse sentido, o orçamento destinado ao PNAES, que em 2008 era de R \$ 126,3 milhóes, passou para R \$ 643 milhóes em 2013. Apesar de, a priori, o valor

46. Mais informações em Campos, Feres Júnior e Daflon (2013).

47. Decreto no 7.234, de 19 de julho de 2010 (Brasil, 2010b). 
ter aumentado, este ainda é considerado insuficiente para conseguir responder de forma efetiva a demanda apresentada por essa nova realidade universitária. Segundo a Associação Nacional dos Dirigentes das Instituiçóes Federais de Ensino Superior (Andifes) esse valor só atende $24 \%$ de estudantes em situação de vulnerabilidade socioeconômica. Para a associação, seria necessário pelo menos $\mathrm{R} \$ 1,4$ bilhão para poder dar efetividade ao PNAES.

Uma política de assistência estudantil precisa ser pensada em uma perspectiva ampla, não apenas sob o aspecto financeiro. Além da transferência de renda, fundamental para a execução da política, é necessário garantir o seu atrelamento à universalização das informaçóes e, sobretudo, o acesso a processos formativos educacionais, como a pesquisa e extensâo, remunerada ou não, garantindo assim a democratização plena do ensino superior.

\subsection{A Lei no $12.711 / 2012$}

A Lei no 12.711/2012 pode ser considerada um marco divisor nas políticas de ação afirmativa de ingresso no ensino superior. Ainda que a chamada "Lei de Cotas" abranja somente as Ifes, acaba por consolidar uma política afirmativa nacional, com potencial de influenciar tanto a adoçáo como o perfil de AA nas demais IES no Brasil. ${ }^{48}$

A mencionada lei estabelece reserva de vagas para estudantes de escolas públicas, com subcotas de renda e etnorracial. Apesar dos recortes previstos, o principal critério desta medida afirmativa é procedência de escola pública, eixo predominante nos programas de açáo afirmativa para acesso ao ensino superior em curso até o advento desta norma.

De acordo com a Lei, as Ifes devem, até 2016, gradativamente implantar cotas para estudantes de escolas públicas, atendendo à reserva de vagas para estudantes negros e indígenas. O disposto no Artigo 8o desta Lei faculta implementação gradual da medida: $25 \%$ a cada ano, até a totalidade da reserva de vagas em $2016 .{ }^{49}$

Quando plenamente implementada, a reserva de vagas deve funcionar da seguinte forma: $50 \%$ do total de vagas ofertadas por Ifes serão reservadas para estudantes de escola pública. Dentro dessas vagas, estabelecem-se duas subcotas: i) $50 \%$ para estudantes com renda per capita inferior a 1,5 salário mínimo e ii) percentual de reserva para estudantes pretos, pardos e indígenas (PPI), conforme proporção dessas populaçóes na UF, de acordo com o IBGE.

48. A Lei inclui instituições federais de ensino técnico de nível médio (Artigo 4o da Lei no 12.711/2012). Para mais informaç̃̃es sobre a Lei no 12.711/2012, sua tramitação e escopo, ver o número 21 deste periódico.

49. A medida também vale para o ensino técnico/profissional. A lei foi regulamentada pelo Decreto no 7.824 e pela Portaria Normativa no 18 do Ministério da Educação (MEC). Para mais informações, consultar o número 20 deste periódico. 
O Instituto Militar de Engenharia (IME) e o Instituto Tecnológico de Aeronáutica (ITA) podem ser observados como casos especiais em relação à Lei de Cotas. Por estarem vinculados ao Ministério da Defesa, não ao Ministério da Educaçáo, esses Institutos federais não estáo obrigados a cumprir a determinaçáo da Lei federal, por mera interpretaçáo literal da lei ${ }^{50}$. Apesar de não estarem obrigados, compete aos mesmos, por meio de sua autonomia, criar mecanismos que os coloquem em sintonia com as demais Ifes.

A promulgação da Lei de Cotas sociais com recorte racial mostrou-se tímida, diante de um panorama favorável ao desafio que é o enfrentamento às desigualdades e a promoção da igualdade racial. Cotas raciais, a um só tempo, reconhecem o papel que a discriminação racial exerce na vida das pessoas negras e a abissal distância entre o percentual de pessoas negras e brancas cursando o ensino superior no Brasil. Açóes afirmativas raciais não precisam estar subordinadas a critérios socioeconômicos, conforme reconheceu o STF, declarando a constitucionalidade de cotas raciais independentes.

Apesar das limitaçóes, a Lei de Cotas reforçou a importância das especificidades de grupos populacionais em maior situação de vulnerabilidade. A obrigatoriedade de inclusão de cotas para pretos/as, pardos/as e indígenas, fazendo ainda um recorte de renda, fez com que as Ifes mais resistentes à questão racial, por força de lei, adotassem políticas afirmativas para a população negra.

Conforme editais divulgados em 2013 sobre seleçáo de alunos, identifica-se que $67 \%$ das Ifes abdicaram da implantação gradual e já estabeleceram, em seus certames, o percentual final de reserva de vagas apresentado pela lei federal $(50 \%)$, com cumprimento previsto para até 2016. Entre os Institutos Federais, 87,5\% já alcançaram a meta de 2016, ou seja, 35, dos quarenta existentes, já estấo cumprindo os $50 \%$ de reserva de vagas.

Nas universidades federais, esse número é um pouco menor, já que 33 das 59 instituiçóes cumprem os $50 \%$ previstos pela Lei de Cotas. Apesar de representar percentual de adesão plena inferior àquele referente aos institutos federais, 56\% das universidades federais já cumprem a meta de 2016.

Até 2012 apenas quatro universidades federais adotaram ação afirmativa com critério racial sem a necessidade de outros condicionantes. Esse número significa que apenas $9,75 \%$ de medidas afirmativas adotadas por essas instituiçóes adotavam cotas raciais independentes.

50. Artigo 1ํ. As instituições federais de educação superior vinculadas ao Ministério da Educação reservarão, em cada concurso seletivo para ingresso nos cursos de graduação, por curso e turno, no mínimo 50\% (cinquenta por cento) de suas vagas para estudantes que tenham cursado integralmente o ensino médio em escolas públicas. (Lei no 12.711/2012). 
TABELA 5

Ifes com ações afirmativas com recorte racial - antes e depois da Lei de Cotas (2012 e 2013)

\begin{tabular}{|c|c|c|c|c|c|c|c|c|}
\hline \multirow[b]{2}{*}{ Ifes } & \multicolumn{3}{|c|}{2012} & \multirow[b]{2}{*}{$(\%)$} & \multicolumn{3}{|c|}{2013} & \multirow[b]{2}{*}{$(\%)$} \\
\hline & Total & $\begin{array}{c}\text { Total com } \\
\text { AAs }\end{array}$ & $\begin{array}{l}\text { AAs com } \\
\text { recorte racial }\end{array}$ & & Total & $\begin{array}{c}\text { Total com } \\
\text { AAs }\end{array}$ & $\begin{array}{l}\text { AAs com } \\
\text { recorte racial }\end{array}$ & \\
\hline Universidades federais & 59 & 49 & 23 & 46,9 & 59 & 59 & 59 & 100,0 \\
\hline Institutos federais & 40 & 33 & 05 & 15,1 & 40 & 40 & 40 & 100,0 \\
\hline Total & 99 & 82 & 28 & 34,1 & 99 & 99 & 99 & 100,0 \\
\hline
\end{tabular}

O fato de apenas 34\% das Ifes com AA incluir espontaneamente recorte racial até 2012 ilustra a resistência que ainda afeta esta temática. A maioria dos Institutos federais não trazia o recorte racial. Dentre esses institutos em todo o país, apenas 05 IF promoviam a inclusão de pessoas negras. ${ }^{51} \mathrm{O}$ perfil geral que vinha sendo adotado por estes institutos era apenas o recorte socioeconômico com base na origem de escola pública.

Com a adoção da Lei de Cotas, o cenário apresentado, por força legal, mudou significativamente. Esse é um dos principais diagnósticos percebidos nos primeiros dois anos de vigência da Lei no 12.711/2012 (Brasil, 2012b). A tabela 6 ilustra as alteraçôes na distribuição das vagas em Universidades Federais.

TABELA 6

Vagas reservadas pela Lei de Cotas em universidades federais (2012 a 2014)

\begin{tabular}{lccc}
\hline & 2012 & 2013 & 2014 \\
\hline Vagas ofertadas & 140.303 & 188.735 & 191.736 \\
Vagas para ampla concorrência & 110.039 & 129.303 & 114.362 \\
Vagas reservadas & 30.264 & 59.432 & 77.374 \\
Vagas reservadas para escola pública e baixa renda & 16.677 & 21.608 & 29.813 \\
Vagas reservadas para PPIs (pretos, pardos e indígenas) & 13.392 & 37.028 & 43.613 \\
\hline
\end{tabular}

Fonte: Gemaa/UERJ (Daflon, Feres Júnior e Moratelli, 2014).

Elaboração dos autores.

51. Instituto Federal de Educação, Ciência e Tecnologia Baiano/BA; Instituto Federal de Educação, Ciência e Tecnologia da Bahia/BA; Instituto Federal de Educação, Ciência e Tecnologia do Paraná/PR; Instituto Federal de Educação, Ciência e Tecnologia de Santa Catarina/SC; Instituto Federal de Educação, Ciência e Tecnologia Farroupilha/RS. 
No que tange especificamente à pauta racial, o que se percebe é que houve um incremento significativo no número de vagas reservadas para PPIs em universidades federais. O aumento foi de $226 \%$, mais que duplicando o número de vagas para esse público.

Um dos desafios da Lei de Cotas é conseguir fazer com que o cumprimento da determinação legal não signifique um retrocesso no que tange à adoção de políticas de promoção da igualdade racial já adotada por algumas Ifes. No Instituto Federal de Educação, Ciência e Tecnologia do Paraná e na Universidade Federal do Paraná que adotavam cotas raciais independentes, ${ }^{52}$ no processo de adaptação, foram abandonadas as cotas raciais sem recorte socioeconômico, passando a cumprir estritamente a determinação da Lei de Cotas.

Por outro lado, em outras Ifes o processo de adequação tomou outra direção, como o caso da UnB, que estabeleceu, além do percentual mínimo exigido pela Lei, a reserva de mais $5 \%$ para estudantes negros/as, sem a necessidade de outro critério. Assim também é o caso do IFPB, que reserva, além do percentual previsto pela Lei, mais 5\% para deficientes físicos e 20\%, no campus de Sousa (PB), para pessoas que vivem em assentamentos de reforma agrária. Também foi o caminho adotado pela Universidade Federal de Santa Catarina, que, além das vagas reservadas por lei, faz a reserva de $10 \%$ de vagas para estudantes negros, prioritária, mas não exclusivamente, para estudantes de escola pública.

Levando em consideração que $87,4 \%$ dos/as estudantes do ensino médio no Brasil são oriundos/as de escola pública, ${ }^{53}$ a Lei de Cotas, garantindo a reserva de $50 \%$ das vagas em Ifes para esses estudantes, tem enorme potencial de democratizar o ensino superior público.

Uma inovação neste campo foi implementada pelo Governo do Rio de Janeiro, que, por meio da Lei no 6.914, de 6 de novembro de 2014, estabeleceu sistema de cotas para ingresso nos cursos de pós-graduação em universidades estaduais públicas. Submetidas ao critério socioeconômico, foram instituídas cotas de 12\% para negros e indígenas, $12 \%$ para egressos da rede pública e privada (neste caso, ex-beneficiários de financiamento estudantil ou bolsas), e $6 \%$ para grupos diversos, ${ }^{54}$ limitadas a $20 \%$ do total de vagas de cada curso. Os cursos de sociologia da UnB e de Antropologia da Biblioteca Nacional já tinham adotado medidas semelhantes.

52. IFET/PR 20\% para candidatos de escolas públicas; $20 \%$ para negros; $4 \%$ para indígenas e $4 \%$ para pessoas com deficiência; UFPR: 20\% para negros; $20 \%$ para candidatos de escolas públicas; dez vagas para indígenas e uma vaga para pessoa com deficiência.

53. IBGE, microdados do censo 2010.

54. Pessoas com deficiência, nos termos da legislação em vigor, filhos de policiais civis e militares, bombeiros militares e inspetores de segurança e administração penitenciária, mortos ou incapacitados em razão do serviço. 
No que tange ao ensino superior, além das açóes afirmativas nas IES, não se pode olvidar da importância que o Exame Nacional do Ensino Médio (Enem) e Sistema de Seleção Unificada (Sisu) adquiriram especialmente nos últimos anos. Como política do MEC, tanto Enem como o Sisu têm assumido caráter central no que se refere ao ingresso em IES, públicas e privadas.

Criado em 1998, o Enem passou desde 2009 a ser utilizado como mecanismo de seleção em IES, ganhando importância na própria construção do currículo escolar da educação básica. O Sisu, como plataforma virtual administrada pelo MEC, tem se tornado a forma mais recorrente de ingresso em IES públicas. No momento de inscrição, o/a estudante pode fazer até duas opçôes de cursos e IES a que deseja concorrer. Também é no momento de inscriçẫo que deverá indicar se concorrerá às vagas da ampla concorrência, optar pelas vagas reservadas pela Lei no 12.711/2012 (Brasil, 2012b) ou alguma outra açẫo afirmativa adotada pela IES.

Em 2013 e 2014, o número de inscritos no Enem bateu todos os recordes dos anos anteriores. Em 2013, o número de inscritos/as chegou a 7.173.574, um aumento de $24 \%$ em relação ao ano de 2012. Em 2014 o número de inscritos/as chegou a 8.721.946, um aumento de $21 \%$ em relação ao ano anterior.

Uma das explicaçóes para o aumento do número de inscriçôes pode estar relacionada à dimensão que o Sisu assumiu nos últimos anos. Das 134 IES públicas existentes no Brasil, 84 adotaram a nota do Enem e aderiram ao Sisu como forma de ingresso. A adesão ao Sisu pode ser de maneira parcial (percentual de vagas) ou total. O número de inscriçôes ao Sisu em 2013 foi de 1.949.958, e, em 2014, foi de 2.004.110.

Uma política nacional de ação afirmativa conjugada com uma política de seleção integrada pode representar uma democratização mais profunda do ensino superior na medida em que rompe com os limites geográficos, permitindo que os estudantes façam escolhas sem que isso represente grande dispêndio de recursos financeiros.

Esta primeira década de açôes afirmativas para o ingresso no ensino superior público no Brasil apresentou muitos avanços, como a inclusão de indivíduos cuja participação no ensino superior, em especial na rede pública, era bastante limitada, residual ou inexistente em alguns espaços.

No que se refere especialmente à população negra, existe um elemento que é fundamental na discussão de acesso ao ensino superior: o escandaloso índice de mortalidade da juventude negra indica que a ampliação de oportunidades para esses jovens negros é condição de vida e existência social, embora o acesso à educação não signifique que esses jovens negros não enfrentarão o racismo presente em todos os setores da sociedade brasileira. 
Em suma, para além das demandas iniciais de ingresso da população negra, o público atingido foi ampliado, com a inclusão, entre os destinatários das medidas afirmativas, de pessoas com deficiência, pessoas com baixa renda, moradores de determinadas regióes, inclusive com atendimento de especificidades locais e regionais.

\subsection{Reserva de vagas para negros no ingresso em quadros da administração pública}

O mundo do trabalho, por ser espaço estruturante na vida social, é um dos campos em que a desigualdade racial se apresenta de modo mais intenso e com maior repercussão para as condiçốes de vida dos indivíduos. Os indicadores de desocupação, renda, trabalho protegido, entre outros, colocam a população negra sempre em posição de maior vulnerabilidade. Mesmo na administração pública os mecanismos pretensamente neutros de seleção de parte do quadro funcional não conseguem superar adequadamente as diferenças experimentadas por brancos e negros. ${ }^{55}$

À medida que o Estado passa a reconhecer os efeitos do racismo e a atuar por meio de ações afirmativas, as contradiçôes dos quadros da administração também passam a ser mais questionadas. As demandas sociais e o reconhecimento das desigualdades raciais e desvantagens históricas acumulativas da população negra no mundo do trabalho propiciaram o desenvolvimento de açóes afirmativas neste campo.

Os primeiros movimentos vieram na órbita do Programa Nacional de Açóes Afirmativas (PNAA), instituído, na administração pública federal, por meio do Decreto no 4.228/2002. O PNAA previa a inclusão de "afrodescendentes, mulheres e pessoas portadoras de deficiência" em cargos em comissão e nas contrataçóes de prestadores de serviço, ${ }^{56} \mathrm{sem}$ abordar, contudo, o tema dos concursos públicos. Em alguns ministérios, foi criado sistema de reserva de vagas para ingresso de servidores e em contrataçóes por meio de prestadores de serviço. Nesse período, foi iniciado o Programa de Ação Afirmativa do Ministério das Relaçôes Exteriores, voltado para o apoio a negros para ingresso na diplomacia. Dessas açóes, esta última é a única que vige até hoje (Volpe e Silva, 2014). ${ }^{57}$

Nesse contexto, fora do âmbito do governo federal, verificou-se, a partir de 2002, o surgimento de legislaçóes que tratavam de ação afirmativa para ingresso de negros em administraçóes estaduais e municipais. A maior parte versava sobre

55. Para mais informações sobre desigualdades raciais no mundo do trabalho e na administração pública, consultar Silva e Silva (2014) e o número 20 deste periódico.

56. O PNAA foi instituído sob a coordenação da Secretaria de Estado dos Direitos Humanos do Ministério da Justiça. No entanto, o decreto nunca foi nem regulamentado, nem revogado. Em pesquisa junto a órgãos da administração pública federal, Osório (2006) constatou que nove entre os 23 ministérios pesquisados não sabiam do que se tratava 0

PNAA. Mesmo entre alguns que afirmaram conhecê-lo, ficou patente o desconhecimento. Em apenas dois ministérios seus representantes confirmaram conhecer o decreto, apesar de não aplicá-lo.

57. Os Ministérios do Desenvolvimento Agrário, da Justiça, da Cultura e o Supremo Tribunal Federal implementaram medidas. Para mais informações, consultar o número 20 deste periódico e Silva e Silva (2014). 
cotas, com percentuais que variavam de $5 \%$ a $44 \%$ das vagas ofertadas. Em menor número, algumas experiências indicavam o estabelecimento de metas percentuais para alcance de maior participação de negros, à semelhança do proposto no PNAA. ${ }^{58}$

Levantamento realizado por Volpe e Silva (2014) identificou, até 2012, a adoção de açóes afirmativas em quatro estados e 46 municípios, algumas delas, descontinuadas. A reserva de vagas também foi estipulada em outras esferas de atuaçáo do poder público, além do concurso, como estágio, cargo em comissão, prestadores de serviço e publicidade. As referidas açóes afirmativas concentravam-se nas regióes Sudeste e Sul, com respectivamente 50\% e 42\% das observaçóes até 2012.59

Entre 2013 e 2014, o quadro das reservas de vagas na administração pública foi ganhando novos contornos. Dentre os fatos mais importantes, está, sem dúvida, a promulgação da Lei $\mathrm{n}^{\circ}$ 12.990/2014, que estabeleceu cotas para negros em concursos da administração pública federal, direta e indireta.

\subsubsection{Aprovação da Lei de Cotas federal (Lei no 12.990/2014)}

Durante a III Conferência Nacional de Promoção da Igualdade Racial (CONAPIR), a presidente Dilma anunciou o envio ao Congresso Nacional, em caráter de urgência, de Projeto de Lei (PL) que versava sobre reserva de $20 \%$ das vagas para negros em concursos públicos da administração pública federal (PL no ${ }^{\circ}$ 6738/2013).

O PL tramitou no Congresso entre novembro de 2013 e junho de 2014, quando foi aprovado. Por meio de acordos, seguiu sem alteraçóes e com votaçóes majoritariamente favoráveis. Algumas emendas foram apresentadas e sistematicamente rejeitadas:

Na tramitação do PL na Câmara dos Deputados foram apresentadas seis emendas à matéria: $i$ ) extensão da reserva de vagas aos cargos em comissão; ii) ampliação do percentual de reserva de vagas para $30 \%$, incluindo indígenas; iii) alteração da vigência da lei para prazo indeterminado; iv) preenchimento dos cargos em comissão em percentuais paritários aos pretos, pardos e brancos; $v$ ) ampliação do percentual de reserva de vagas para $50 \%$; e vi) extensão da reserva de vagas para os Poderes Judiciário e Legislativo" (Laeser, 2014, p. 3).

A lei prevê que a cota seja aplicada em todo concurso público da administração pública federal, direta e indireta, com número de vagas igual ou superior a três; estabelece o critério da autodeclaração; define que os candidatos concorrerão em duas listas - de vagas reservadas e na ampla concorrência, evitando a formação de "teto"; indica responsáveis por avaliação anual e fixa em 10 anos a vigência da norma.

58. Para mais informações sobre a trajetória das ações afirmativas na administração pública, consultar Silva e Silva (2014) e o número 20 deste periódico.

59. Análise sobre 0 assunto foi realizada no número 20 deste periódico, no capítulo Igualdade racial. 
$\mathrm{Na}$ ausência de regulamentação ou outro nível de orientaçôes, os órgãos promotores de concursos acabaram por introduzir algum grau de adequação e aperfeiçoamento da norma. Os primeiros concursos realizados a partir da vigência da lei foram promovidos pelo Instituto Federal de Brasília (editais nos 001 e 002/2014). ${ }^{60}$ No edital dos certames, estabelece-se que documento de "autodeclaraçáo étnico racial" seja encaminhado por meio dos correios, como forma de validação para concorrência às vagas reservadas. A elaboração de um documento à parte para declaração racial também foi procedimento adotado em concursos seguintes, como o da Anatel. ${ }^{61} \mathrm{O}$ quadro 2 apresenta alguns procedimentos não necessariamente disciplinados pela Lei, mas que foram adotados por órgãos do governo federal para implementação da reserva de vagas.

QUADRO 2

Procedimentos adotados para aplicação da Lei de $\operatorname{Cotas}^{62}$

\begin{tabular}{|l|l|l|}
\hline \multicolumn{1}{|c|}{ Categoria } & \multicolumn{1}{|c|}{ Procedimento } & $\begin{array}{c}\text { Concurso/processo } \\
\text { seletivo }\end{array}$ \\
\hline Autodeclaração & $\begin{array}{l}\text { Exige documento de autodeclararão étnico racial no momento da inscrição. A } \\
\text { declaração deve ser enviada por correios para validação da inscrição como negro. }\end{array}$ & IFB/Anatel \\
$\begin{array}{l}\text { Cadastro de } \\
\text { reserva }\end{array}$ & $\begin{array}{l}\text { Para os cargos/polos de trabalho em que não existe previsão inicial de reserva de } \\
\text { vaga para pessoa preta ou parda, será formado cadastro no quantitativo de 30\% } \\
\text { (trinta por cento) do cadastro esperado para ampla concorrência }\end{array}$ & $\begin{array}{l}\text { Petrobras. Edital no 1, } \\
\text { de 11 de setembro de } \\
2014 . \text { Item 3.2.1.2.1 }\end{array}$ \\
$\begin{array}{l}\text { Comissão } \\
\text { específica }\end{array}$ & $\begin{array}{l}\text { Estabelece comissão formada de empregados da empresa, distribuídos por } \\
\text { gênero, cor e região geográfica, que irá avaliar a condição de preto e pardo } \\
\text { dos candidatos, considerando os seguintes aspectos: a informação prestada na } \\
\text { inscrição e a autodeclaração apresentada na fase de comprovaça de requisitos } \\
\text { e o fenótipo. O não enquadramento implica exclusão do processo seletivo. }\end{array}$ & $\begin{array}{l}\text { Petrobras. Edital no 1, } \\
\text { de 11 de setembro de } \\
2014 \text {. Item 3.2.7. }\end{array}$ \\
$\begin{array}{l}\text { Critérios de } \\
\text { preenchimento } \\
\text { das vagas reser- } \\
\text { vadas para negros } \\
\text { e pessoas com } \\
\text { deficiência }\end{array}$ & $\begin{array}{l}\text { Os candidatos negros aprovados dentro do número de vagas oferecido à ampla } \\
\text { concorrência não preencherão as vagas reservadas a candidatos negros. } \\
\text { Os candidatos negros aprovados dentro do número de vagas oferecido às vagas } \\
\text { reservadas a pessoa com deficiência não preencherão as vagas reservadas a } \\
\text { candidatos negros. } \\
\text { Os candidatos negros que perderam o direito de concorrer às vagas reservadas } \\
\text { às pessoas com deficiência figurarão na lista de candidatos negros. }\end{array}$ & $\begin{array}{l}\text { Edital no 55/2014: } \\
\text { concurso público para } \\
\text { provimento de vagas } \\
\text { no cargo de agente de } \\
\text { polícia federal }\end{array}$ \\
\hline
\end{tabular}

Fonte: Editais dos concursos/processos seletivos do IFB, Anatel, Petrobras e Política Federal. Elaboração dos autores.

60. 0 primeiro teve como objetivo provimento de 158 vagas para técnico administrativo, das quais 28 foram reservadas para negros. No segundo, voltado para seleção de professores, três das treze vagas foram objeto da cota. Disponível em: <http://www.ifb.edu.br/certames/concursos>.

61. A este respeito ver <http://www.cespe.unb.br/concursos/anatel_14/>. Esta exigência não aparece no edital da ANTAQ, disponível em: <http://goo.gl/L7wgkU>.

62. Subordinado a Lei de Cotas específica, o município de Salvador adotou critério de convocação explícito "a convocação dos candidatos aprovados será de acordo com a ordem de classificação geral no Processo Seletivo Simplificado mas, a cada fração de 5 (cinco) candidatos, a quinta vaga fica destinada a candidato afrodescendente aprovado, de acordo com a sua ordem de classificação na lista específica" (Salvador, 2014) e Edital de concurso público no 01/2014/SEMGE de 15 de setembro de 2014. 
O ponto de maior controvérsia, sem dúvida, volta-se para a autodeclaração e a criaçáo de comissão específica para sua verificação. Embora não seja critério definido pela lei, nem adotado por todos os órgãos, a possibilidade de criação de instância para validar a declaraçáo racial foi considerada adequada no julgamento das cotas na UnB no STF. ${ }^{63}$

Ainda que o critério de autodeclaração seja o preferível, tendo em vista a possibilidade de fraudes e a busca por garantir o melhor resultado da política, o ministro relator da ADPF 186 validou as orientaçóes para comissão de avaliação do critério racial, apresentadas por Daniela Ikawa na obra Açôes Afirmativas em Universidades:

A identificação deve ocorrer primariamente pelo próprio indivíduo, no intuito de evitar identificaçóes externas voltadas à discriminação negativa e de fortalecer o reconhecimento da diferença. Contudo, tendo em vista o grau mediano de mestiçagem (por fenótipo) e as incertezas por ela geradas - há (...) um grau de consistência entre autoidentificação e identificação por terceiros no patamar de 79\% -, essa identificação não precisa ser feita exclusivamente pelo próprio indivíduo. Para se coibir possíveis fraudes na identificação no que se refere à obtenção de benefícios e no intuito de delinear o direito à redistribuição da forma mais estreita possível (...), alguns mecanismos adicionais podem ser utilizados como: (1) a elaboração de formulários com múltiplas questóes sobre a raça (para se averiguar a coerência da autoclassificaçáo); (2) o requerimento de declaraçôes assinadas; (3) o uso de entrevistas (...); (4) a exigência de fotos; e (5) a formação de comitês posteriores à autoidentificação pelo candidato. A possibilidade de seleçâo por comitês é a alternativa mais controversa das apresentadas (...). Essa classificação pode ser aceita respeitadas as seguintes condiçôes: (a) a classificaçáo pelo comitê deve ser feita posteriormente à autoidentificaçáo do candidato como negro (preto ou pardo), para se coibir a predominância de uma classificaçấo por terceiros; (b) o julgamento deve ser realizado por fenótipo e não por ascendência; (c) o grupo de candidatos a concorrer por vagas separadas deve ser composto por todos os que se tiverem classificado por uma banca também (por foto ou entrevista) como pardos ou pretos, nas combinaçôes: pardo-pardo, pardopreto ou preto-preto; (d) o comitê deve ser composto tomando-se em consideração a diversidade de raça, de classe econômica, de orientação sexual e de gênero e deve ter mandatos curtos" (Ikawa apud Lewandowski, 2012, p. 39).

Por sua vez, a aplicação da Lei está restrita a cargos com três ou mais vagas, de modo que quadros funcionais pequenos ou nos quais a reposição seja feita de forma fragmentada terão pouco impacto da normativa. Este é o caso dos concursos para docentes de ensino superior. Diferentemente do caso do IFB, em concursos recentes para magistério superior, as cotas não tiveram repercussão, haja vista o número limitado de vagas ${ }^{64}$ (Silva e Silva, 2014). Desta forma, há que se analisar

63. Para mais informações sobre a ADPF 186, consultar Silva e Silva (2013).

64. Exemplos de editais disponíveis em <http://dgp.unb.br/concursos/docente-2014>. 
estratégias possíveis para que o corpo docente das universidades, campo de formação do debate sobre cotas no Brasil, não passe ao largo dos avanços conquistados pela recente legislação. Neste espaço, uma forma de garantir maior número de vagas por concurso é que o certame seja realizado por área de conhecimento e náo mais por disciplinas específicas.

A sistematização das iniciativas mais exitosas na operacionalização da reserva de vagas é tarefa premente para o governo federal, de modo que os executores de concursos e processos seletivos tenham à disposiçẫo conhecimento sobre os procedimentos mais adequados para viabilizar melhor funcionamento da ação afirmativa. O compartilhamento dessas experiências tende, por seu turno, a minimizar eventuais questionamentos e consequentes obstáculos à consecução dos certames, além de garantir melhor fruição do direito por parte da população negra.

De fato, o próprio instrumento do concurso público precisa ser repensado, no bojo de uma estratégia de maior democratização dos quadros da administração pública. Nesse sentido, as cotas não podem ser encaradas como uma panaceia, mas antes como uma dentre outras medidas necessárias para este processo. Assim, cabe destacar que, quando o Ministério das Relaçôes Exteriores implementou o Programa de Ação Afirmativa para negros, o fez em conjunto com uma reformulação mais ampla do processo seletivo para admissáo de diplomatas, eliminando conteúdos e etapas que excluíam, de partida, candidatos oriundos de classes populares, a exemplo de questóes pontuais sobre história da arte e entrevistas em inglês. $\mathrm{Na}$ mesma direção, concursos que exigem do candidato deslocamentos à sua própria custa, como foi o último certame do próprio Ipea, na sua fase de entrevistas, acabam por restringir a participação dos candidatos em igualdade de oportunidades.

Por fim, a Lei no 12.990/2012 foi questionada no Supremo Tribunal Federal por meio do Mandado de Segurança (MS no 33.072), impetrado em julho de 2014. Na ação, o Instituto de Advocacia Racial e Ambiental (Iara) requeria que, além do executivo, os demais poderes federais também obedecessem à legislação em seus certames. Conforme notícia do STF,

o processo ainda questiona a ausência, na Lei 12.990/2014, de dispositivo que assegure a igualdade de gênero para as mulheres, e pede liminarmente a inclusão da cota racial em um concurso público autorizado pelo Tribunal de Contas da União (MS..., 2014).

Por conta disso, alguns concursos aguardavam decisão para ser iniciados. ${ }^{65}$ No entanto, em agosto de 2014, o STF negou seguimento ao MS por avaliar que não era a ação adequada para o pleito, entre outras razóes aventadas na decisão (Decisão..., 2014 e STF, 2014). O processo ainda vai para plenário.

65. A este respeito ver $<$ http://goo.gl/CcfdVb $>$. 
3.3.2 Novas leis e perspectivas para reserva de vagas para negros na administração pública Além da Lei no 12.990/2014, outras normas recentes incrementaram o quadro das iniciativas de ação afirmativa para negros na administração pública. Em levantamento não exaustivo, ${ }^{66} \mathrm{o}$ quadro atual de reserva de vagas para negros pode ser ilustrado pelo apêndice $A$.

Um levantamento anterior (Volpe e Silva, 2014) já informava que as normas desta modalidade de ação afirmativa concentravam-se nas regióes Sul e Sudeste. No Norte-Nordeste, apenas a cidade de Sousa, na Paraíba, havia implementado uma política nesse sentido, aparentemente não mais vigente. Apenas em 2011, o município de Salvador adotou a cota, mas, sem concursos públicos no espaço de dois anos, a norma teve efeitos apenas em 2014.

Novas leis foram aprovadas entre 2013 e 2014. Dentre elas, pode-se destacar a reserva de vagas no estado da Bahia, no estado e no município de São Paulo. O governo da Bahia ${ }^{67}$ estabeleceu cota de $30 \%$ em concursos públicos. Antes, o estado de São Paulo havia também apresentado seu Programa Estadual de Inclusão, que tem como meta a participaçáo proporcional de $35 \%$ de negros no quadro de servidores ativos em cinco anos ( $0,19 \%$ para indígenas). De acordo com o Programa, será estabelecida pontuação diferenciada para pretos, pardos e indígenas em concursos públicos, seleção de estagiários, além de bolsas de estudos e vagas em cursos oferecidos pelo estado, à semelhança da modalidade de açáo afirmativa adotada em IES paulistas. ${ }^{68}$ Por sua vez, o município de São Paulo aprovou, em dezembro de 2013, lei que estabelece cotas de $20 \%$ para negros na administração direta e indireta, para cargos efetivos, em comissão e estágio profissional, garantida a equidade de gênero. A norma estabelece a criação de uma Comissão de Monitoramento e Avaliação e prevê atualização dos dados cadastrais e ajustes em sistemas de $\mathrm{RH}$ e formulários para possibilitar monitoramento. ${ }^{69}$

Durante a tramitação do PL das cotas no Senado, a Mesa Diretora anunciou que o Senado Federal também adotaria reserva de $20 \%$ das vagas para negros em concursos públicos para cargos efetivos e "nos contratos de prestação de serviços continuados e terceirizados” (Mendes, 2014 e Senado, 2014c, seção II). ${ }^{70}$ A adoção de sistema de cotas segue em discussão em outras localidades: ${ }^{71}$ em Rio Branco,

66. Foram relacionadas as leis captadas por meio de notícias, informação de sites governamentais e de gestores e ativistas. 67. A este respeito ver o Estatuto Da Igualdade Racial Da Bahia (Lei no 20785/2014).

68. Conforme Decreto no 59.900/2013. Em 15 de janeiro de 2015, foi aprovada a Lei Complementar no 1.259 do estado de São Paulo, que autoriza o poder executivo a instituir sistema de pontuação diferenciada em concursos públicos para pretos, pardos e indígenas, detalha seus critérios e define prazo para regulamentação.

69. Lei 15.939/2013, Decreto ํㅜ 54.949/14.

70. Não foi especificado número mínimo de vagas para incidência das cotas.

71. A exemplo dos municípios de Santos e Presidente Prudente. A este respeito ver <http://goo.gl/orjDLw> e <http:// goo.gl/WsCNIC> 
por exemplo, foi aprovada uma legislação para garantir maior participação de negros em peças publicitárias veiculadas pela administração municipal. ${ }^{72}$

Uma nova fronteira para o debate de cotas para negros em concursos públicos foi aberta com os encaminhamentos ao Pedido de Providências ao Conselho Nacional de Justiça (CNJ), sobre cotas para negros e indígenas no Judiciário. Para analisar a questão, foi constituído grupo de trabalho, formalizado pela Portaria no 24, de 21 janeiro de 2013. Um dos resultados dessa mobilização foi a realização do censo do Poder Judiciário. Por meio de questionário eletrônico sigiloso, a coleta de dados foi realizada no segundo semestre de 2013. O censo abordou, além do perfil de servidores e magistrados, outros temas, como motivação para o trabalho e satisfação com políticas institucionais. Segundo o CNJ (2014a), 60\% dos servidores e $64 \%$ dos magistrados em atividade responderam à pesquisa (170.746 servidores e 10.796 magistrados).

Entre os magistrados, a maioria é formada por homens $(64,1 \%)$ e por brancos $(82,8 \%) .{ }^{73} \mathrm{O}$ maior ingresso percentual de negros ocorreu entre 2012 e 2013 (19,1\% dos ingressos). Entre 2002 e 2011, negros representaram 15,5\% dos ingressos. Como era esperado, a menor participação de magistrados negros está localizada nos postos mais elevados da carreira, nos tribunais superiores $(8,9 \%)$, e a maior, na Justiça Eleitoral (22,5\%). Entre os demais servidores, 56,2\% são mulheres e $69,1 \%$ são brancos. ${ }^{74}$ Neste segmento, desde 2002, 29\% dos ingressantes foram negros. No entanto, cabe destacar que o percentual de negros entre os ingressantes efetivos de 1962 a 1971 era maior (37,6\%). A partir desse período, o percentual de negros ingressantes varia de 26 a 29\%. Por sua vez, entre os servidores, a presença de negros é maior nos tribunais superiores $(37,2 \%)$ e menor na justiça federal $(24,0 \%)$.

Os dados divulgados por cor ou raça só cobrem cruzamentos por ano de ingresso, sexo e ramos da justiça, não sendo possível verificar as funçóes e vínculos destes servidores pelo recorte racial. Assim, embora o censo tenha sido realizado para dar conta da análise do perfil racial do Judiciário, as poucas desagregaçôes com recorte racial dificultam a visualização das desigualdades raciais, especialmente no caso dos servidores. Observa-se também que, ainda que a motivação da enquete tenha sido o mote racial, outros temas acabaram ganhando mais destaque na pesquisa. Há uma seção específica sobre as opinióes das magistradas sobre desigualdade de gênero, mas o mesmo enfoque não é dado à desigualdade racial.

Como se tratam de dados preliminares, como anuncia o documento, a expectativa é que futuras publicaçôes possam aprofundar o desenho do perfil racial especialmente dos servidores, tendo em vista que, para os magistrados,

72. A este respeito ver <http://goo.gl/iYdnfj>.

73. 1,4\% preto; $1,5 \%$ amarela; $14,2 \%$ pardo e 0,1\% indígena. (CNJ, 2014a, p. 41).

74. 4,1\% preto; $1,9 \%$ amarela; $24,7 \%$ pardo e $0,3 \%$ indígena (CNJ, 2014a, p. 120). 
a baixa participação de negros é evidente. Também seria interessante se o CNJ disponibilizasse a base de dados não identificada da pesquisa, possibilitando aos interessados produzir suas próprias estatísticas.

Na mesma dinâmica foi apresentado, pela ONG Educafro, o Pedido de providências ${ }^{75}$ referente à implementação de cotas para negros no Ministério Público do Trabalho. Indeferido no órgáo de origem, a análise do pleito foi estendida a todo Ministério Público da União e Estados, ultimando em avaliação do Conselho Nacional do Ministério Público (Comissão de Defesa dos Direitos Fundamentais). Para subsidiar a análise, foi realizada, em setembro de 2014, audiência pública com escuta de diversos atores sociais envolvidos com o tema, ${ }^{76}$ para melhor embasamento dos conselheiros sobre o assunto.

\subsubsection{Acompanhamento do quadro de leis já implementadas: dilemas e perspectivas}

\section{Contestações}

Muitas legislações enfrentaram contestaçôes de ordem administrativa e/ou judicial, embora diversas leis sequer tenham protagonizado maiores conflitos na ocasião de sua aprovação (Volpe e Silva, 2014). Para além dos questionamentos individuais, algumas leis foram suspensas ou declaradas inconstitucionais, outras ainda passam por intermináveis batalhas, como é o caso da Lei de cotas de Vitória.

Ações afirmativas derrubadas por ação de inconstitucionalidade, como em Cachoeira do Sul, Rio de Janeiro e Vitória, foram substituídas por outras legislaçóes. No caso de Vitória, também a segunda lei se encontra em apreciação do Tribunal de Justiça do Estado.

No conjunto das açóes impetradas, o vício material foi aventado, especialmente, na alegação de atentado à isonomia e justificativas assemelhadas. O problema do vício de iniciativa igualmente embasou alguns processos. Nestes, afirmou-se a tese de que a iniciativa de lei que versa sobre o regime jurídico dos servidores deve ser de iniciativa do Poder Executivo, de modo que algumas leis de iniciativa do Legislativo foram suspensas. No entanto, esse entendimento não é pacífico, visto que outras tantas leis que seguiram o mesmo processo legislativo não foram questionadas ou que essa hipótese foi afastada em alguns julgamentos. Entende-se a ação afirmativa foi considerada como meio de concretização de direito fundamental, sem afetar o regime jurídico dos servidores, apenas sua forma de ingresso (Espírito Santo, 2010, p. 29-30).

A expectativa é que, com a Lei de Cotas no governo federal e a disseminação das experiências vigentes, formulem-se ou reformulem-se as iniciativas de ação

75. Pedido de Providências no 543/2013-50, disponível em: <http://goo.gl/2ZEz5q>.

76. Para mais informações, consultar o edital da audiência pública, disponível em: <http://goo.gl/EnbnLN>. 
afirmativa dentro de consensos mínimos que reduzam as controvérsias, pelo menos no campo formal e nas alegaçóes de inconstitucionalidade.

Monitoramento e avaliação dos sistemas de reserva de vagas

Com a implementaçáo de uma política de reserva de vagas em concursos, além do aumento da participação de negros nos cargos públicos de maior poder e prestígio, esperam-se outros efeitos positivos experimentados, por exemplo, na trajetória das Instituições de Ensino Superior (IES): ampliação do debate público e institucional sobre racismo, desenvolvimento de estratégias institucionais de enfrentamento ao racismo, incorporação de outras lógicas de ação a compor as equipes e processos decisórios. Todavia, para formular, acompanhar e avaliar essas políticas incidentes sobre o quadro de pessoal, é necessário ter informação de qualidade, bem como promover sistemas públicos e transparentes de monitoramento das referidas medidas afirmativas.

Nesse sentido, verificam-se limites importantes para esse intento. Quando acessíveis, relatórios baseados em registros administrativos de pessoal geralmente não são divulgados com a inclusão da variável cor ou raça (por inexistência do quesito, incerteza sobre o processo de coleta, alta subnotificaçáo ou falta de interesse da gestão). O Ministério do Planejamento (MPOG) divulga mensalmente boletim sobre a composição do quadro de pessoal, em que apresenta recorte do funcionalismo por sexo, escolaridade do cargo, órgão de lotação, idade média dos servidores, entre outros, sem exibir nenhuma informação sobre o perfil racial. ${ }^{77}$ Ademais, os próprios dados do funcionalismo federal apresentam percentual de subnotificação ainda na casa de 15\% para os servidores ingressos de 2007 a 2012 (Volpe e Silva, 2014).

Na pesquisa realizada pelo Ipea (2014) entre 2011 e 2012, foram mapeadas cinquenta localidades, dentre as quais quatro estados com medidas de ação afirmativa para ingresso de negros nos quadros de pessoal. Questionários foram encaminhados para as áreas de recursos humanos e de igualdade racial ou áreas correspondentes de 41 localidades (nove foram descobertas após esta fase da pesquisa). Apenas nove localidades responderam ao questionário dirigido para a área de recursos humanos, especificamente para o setor responsável pela gestão de concursos públicos. Dessas nove localidades, sete informaram existir, "no quadro da administração direta, algum registro da cor ou raça dos servidores"; destas, apenas cinco confirmaram que "o campo cor ou raça é preenchido com regularidade, sendo possível extrair um perfil atualizado da cor ou raça dos servidores." Ou seja, mesmo entre administraçóes que já implementam políticas de cotas raciais, a informação atualizada sobre o perfil

77. Boletim estatístico de pessoal. Disponível em: $<$ http://www.servidor.gov.br/index.asp?index=65\&ler=s712>. Acesso em: 21 nov. 2013. 
dos servidores nem sempre está disponível. Além disso, na pesquisa, não houve relatos da existência de sistemas de monitoramento contínuo da legislação sobre reserva de vagas. Em alguns casos, o respondente informou que a sistemática de monitoramento estava em implementação; em outros, a administração declarou que os dados sobre resultados da política somente foram sistematizados para atender a demanda da pesquisa. ${ }^{78}$

Por sua vez, pesquisas domiciliares nacionais, ainda que contenham, em sua maioria, a variável cor ou raça em bons níveis de notificação e confiabilidade, nem sempre permitem análise mais acurada das ocupaçóes públicas, que forneçam elementos para análise dos quadros de pessoal de uma determinada localidade, tanto no que se refere ao ingresso, composição e carreiras, como em informaçóes mais sofisticadas, como ascensão e desenvolvimento. Por outro lado, registros administrativos nacionais, a exemplo dos dados do Ministério do Trabalho e Emprego (MTE), apresentam limitaçóes no registro do quesito cor ou raça em geral e para a administração pública, em particular, em que o dado praticamente não é captado pela RAIS (quadro 3).

QUADRO 3

Fontes de dados sobre ocupados por cor ou raça na administração pública

\begin{tabular}{|l|l|l|l|l|}
\hline $\begin{array}{l}\text { Fonte/ } \\
\text { órgão }\end{array}$ & Periodicidade & Abrangência geográfica & $\begin{array}{l}\text { Informações relacionadas } \\
\text { disponíveis }\end{array}$ & \multicolumn{1}{c|}{ Observações } \\
\hline $\begin{array}{l}\text { PNAD/ } \\
\text { IBGE }\end{array}$ & Anual & $\begin{array}{l}\text { Nacional. Não permite } \\
\text { desagregação por } \\
\text { município }\end{array}$ & $\begin{array}{l}\text { Setor do emprego (público } \\
\text { ou privado) } \\
\text { Área do emprego (federal, } \\
\text { estadual, municipal). }\end{array}$ & $\begin{array}{l}\text { Não é possível desagregar administração } \\
\text { direta ou indireta e diferentes poderes. } \\
\text { Pelo caráter amostral, dados por tipo de } \\
\text { ocupação (CBO) não comportam muitas } \\
\text { desagregações. }\end{array}$ \\
\hline $\begin{array}{l}\text { Censo/ } \\
\text { IBGE }\end{array}$ & Decenal & $\begin{array}{l}\text { Nacional. Permite desagre- } \\
\text { gação até nível municipal }\end{array}$ & $\begin{array}{l}\text { Posição na ocupação (fun- } \\
\text { cionário público); atividade } \\
\text { (administração pública) }\end{array}$ & $\begin{array}{l}\text { Só há informação sobre posição na } \\
\text { ocupação, sem variáveis sobre setor e } \\
\text { área do emprego, como na PNAD. }\end{array}$ \\
\hline $\begin{array}{l}\text { Rais/ } \\
\text { MTE }\end{array}$ & Anual & $\begin{array}{l}\text { Nacional. Permite desagre- } \\
\text { gação até nível municipal }\end{array}$ & $\begin{array}{l}\text { Dados do empregado, tipo } \\
\text { de vínculo e empregador }\end{array}$ & $\begin{array}{l}\text { 23,41\% de subnotificação para o } \\
\text { quesito cor ou raça. } \\
91,08 \% \text { dos ocupados em administração } \\
\text { pública em geral (CNAE 75116) não } \\
\text { informaram cor ou raça (Rais 2012). }\end{array}$ \\
\hline $\begin{array}{l}\text { Siape/ } \\
\text { MP }\end{array}$ & $\begin{array}{l}\text { Atualização } \\
\text { contínua }\end{array}$ & $\begin{array}{l}\text { Nacional. Permite desagre- } \\
\text { gação até nível municipal }\end{array}$ & $\begin{array}{l}\text { Pessoal, sem qualquer } \\
\text { recorte por cor ou raça dos } \\
\text { servidores. }\end{array}$ & $\begin{array}{l}\text { 15,4\% de subnotificação do quesito } \\
\text { racial para os ingressos entre 2007 e } \\
2012 \text { (Volpe e Silva, 2014). }\end{array}$ \\
\hline
\end{tabular}

Fonte: Documentação das bases. Brasil (2014d) e IBGE (2013), disponível em: <http://goo.gl//6PjKE>. Elaboração dos autores.

Nota: ${ }^{2}$ PME usa as mesmas questões da PNAD para setor e área de emprego.

Notadamente no atual processo de difusão de ações afirmativas para ingresso de negros na administração pública, é preciso que se avancem com as informaçôes

78. Volpe e Silva (2014). 
dos trabalhadores desse setor, incorporando com qualidade e abrangência o quesito cor ou raça, a fim de permitir efetivo monitoramento das leis - algumas criadas há mais de uma década -, e avaliaçáo de seus resultados.

Por fim, convém ressaltar que a reserva de vagas para ingresso de negros deve também ser adotada como parte de um processo mais amplo de ação afirmativa, no qual, além do ingresso de profissionais negros, a questáo racial e o enfrentamento ao racismo estejam presentes em outros aspectos da administração pública. Formação dos servidores públicos, instrumentos de participação social, critérios de formulaçáo de programas, parâmetros de avaliação das iniciativas governamentais, muitos outros campos carecem da inclusão da perspectiva racial. Ainda que o tema racial tenha conquistado maior espaço na agenda governamental nas últimas décadas, o advento das reservas de vagas para negros traz a oportunidade de aprofundar a problematização sobre o aspecto racial, muito além da porta de entrada da administraçáo pública ou de instâncias específicas. A experiência das universidades ensina que as cotas são apenas o começo.

\subsection{Execução orçamentária}

Obter um orçamento da política de igualdade racial no governo federal é um grande desafio por algumas razóes, entre as quais se destacam três. A primeira diz respeito ao fato de que as políticas de igualdade racial e enfrentamento ao racismo têm natureza transversal, ou seja, devem ser executadas horizontalmente pelos órgãos setoriais, contando, em tese, com a coordenação da Seppir. O segundo motivo, ainda relacionado à natureza da política, é que açôes de promoção da igualdade racial nem sempre são quantificáveis. Por exemplo, uma iniciativa com recorte racial pode envolver a equitativa participação de negros em publicidade, a produçáo de indicadores desagregados por cor ou raça ou a inclusão de conteúdo sobre o tema em programas de formação. $\mathrm{Na}$ verdade, esse tipo de recorte racial é muitas vezes resultado de iniciativas governamentais para garantir transversalidade de políticas públicas de igualdade racial. Atribuir todo o custo de açôes dessa natureza para um "orçamento" de igualdade racial parece refletir pouco a realidade do dispêndio. Igualmente atribuir a um orçamento de igualdade racial montantes despendidos em açóes sem nenhuma preocupaçáo com a questão racial, somente pelo fato de atenderem negros, também não parece razoável.

A terceira razão diz respeito aos instrumentos disponíveis para monitoramento físico e orçamentário. Mesmo em açôes em que a perspectiva racial está posta, nem sempre é possível identificar os recursos despendidos para este objetivo. É o caso de ações amplas, em que parte dos recursos é direcionada para a questão racial, mas não há registros disponíveis sobre esta alocação. Há também as ações específicas aglutinadas, espécie que se tornou mais frequente neste último PPA, que procurou condensar ações e reduzir seu número no orçamento. A aglutinação 
de açóes permite mais flexibilidade na execução, ao passo que reduz a transparência e facilita maior fluidez de compromissos fixados. Por exemplo, na ação orçamentária Apoio ao Desenvolvimento da Educação Básica nas Comunidades do Campo, Indigenas, Tradicionais, remanescentes de Quilombo e das Temáticas de Cidadania, Direitos Humanos, Meio Ambiente e Políticas de Inclusão dos Alunos com Deficiência do programa Educação Básica (MEC), não é possível verificar se foram despendidos recursos com comunidades quilombolas e em que montante. ${ }^{79}$ Além dessas, restam as ações que são específicas e restritas à questão racial. O quadro 4 procura sintetizar essas possibilidades.

QUADRO 4

Programas e ações governamentais com recorte racial PPA

\begin{tabular}{|c|c|c|}
\hline $\begin{array}{l}\text { Ações com } \\
\text { recorte racial }\end{array}$ & Característica & $\begin{array}{c}\text { Ação orçamentária } \\
\text { PPA 2012-2015 (exemplos) }\end{array}$ \\
\hline $\begin{array}{l}\text { Ações universais } \\
\text { sensíveis à promoção } \\
\text { da igualdade racial }\end{array}$ & $\begin{array}{l}\text { Desenvolvem atividades universais, porém incorporam } \\
\text { iniciativas que incluem a temática racial, em diferentes } \\
\text { níveis e profundidade, quer no conteúdo de projetos, em } \\
\text { linhas preferenciais em editais públicos ou na sistemática } \\
\text { de coleta e acompanhamento de dados desagregados, } \\
\text { por exemplo. }\end{array}$ & \\
\hline $\begin{array}{l}\text { Ações universais } \\
\text { com projetos espe- } \\
\text { cíficos de promoção } \\
\text { da igualdade racial }\end{array}$ & $\begin{array}{l}\text { Desenvolvem atividades universais, combinadas com } \\
\text { ações específicas de combate à desigualdade racial, com } \\
\text { recursos destacados, porém, por estarem no âmbito } \\
\text { de uma determinada ação, sem discriminação, não é } \\
\text { possível identificá-los nos instrumentos de planejamento } \\
\text { e orçamento. }\end{array}$ & $\begin{array}{l}\text { 20RJ - Apoio à Capacitação e Formação } \\
\text { Inicial e Continuada de Professores, } \\
\text { Profissionais, Funcionários e Gestores para a } \\
\text { Educação Básica }\end{array}$ \\
\hline \multirow[t]{2}{*}{$\begin{array}{l}\text { Ações específicas } \\
\text { aglutinadas }\end{array}$} & \multirow{2}{*}{$\begin{array}{l}\text { Desenvolvem atividades específicas de combate à } \\
\text { desigualdade racial ou voltadas especialmente para a } \\
\text { população negra. No entanto, como os recursos são } \\
\text { alocados de forma conjunta com outros públicos, não é } \\
\text { possível separar os produtos nos instrumentos de planeja- } \\
\text { mento e orçamento. }\end{array}$} & $\begin{array}{l}\text { 20RS - Apoio ao Desenvolvimento da Edu- } \\
\text { cação Básica nas Comunidades do Campo, } \\
\text { Indígenas, Tradicionais, remanescentes de } \\
\text { Quilombo e das Temáticas de Cidadania, } \\
\text { Direitos Humanos, Meio Ambiente e Políticas } \\
\text { de Inclusão dos Alunos com Deficiência." }\end{array}$ \\
\hline & & $\begin{array}{l}8457 \text { - Apoio a Projetos de Segurança Ali- } \\
\text { mentar e Nutricional para Povos Indígenas e } \\
\text { Povos e Comunidades Tradicionais }\end{array}$ \\
\hline \multirow{2}{*}{$\begin{array}{l}\text { Ações específicas } \\
\text { de promoçãão da } \\
\text { igualdade racial }\end{array}$} & \multirow{2}{*}{$\begin{array}{l}\text { Desenvolvem atividades específicas de combate à desi- } \\
\text { gualdade racial ou voltadas especialmente para a popula- } \\
\text { ção negra, com recursos destacados nos instrumentos de } \\
\text { planejamento e orçamento. }\end{array}$} & $\begin{array}{l}\text { 20KV - Fomento à Difusão e Pesquisas } \\
\text { sobre Cultura e Patrimônio Afro-Brasileiro }\end{array}$ \\
\hline & & $\begin{array}{l}8215 \text { - Atenção à Saúde das Populações } \\
\text { Quilombolas }\end{array}$ \\
\hline
\end{tabular}

Fonte: Adaptado de Silva et al. (2011).

No PPA 2012-2015, houve o desenvolvimento de um documento que procurou agregar açóes consideradas como transversais em 22 grupos de políticas

79. Iniciativa 02CO "Prestação de assistência financeira, técnica e material as escolas, aos profissionais da educação e aos estudantes das redes públicas da educação básica, incluindo programas de transporte, alimentação (inclusive de professores e profissionais de educação básica), assistência à saúde, manutenção escolar, ampliação do tempo e espaços educativos e reforço da autogestão, material didático-escolar, paradidático, periódicos e obras de referência, considerando, entre outras especificidades, 0 atendimento educacional especializado, a acessibilidade, a sustentabilidade socioambiental, as populações do campo, afrodescendentes, indígenas e a educação de jovens e adultos." A este respeito, ver: <http://goo.gl/VKCU3m>. 
específicas: Agendas Transversais (Brasil, 2011d). Além de um capítulo dedicado às açôes que dialogassem com "igualdade racial e comunidades quilombolas", temas como meio ambiente, juventude, água e povos indígenas estavam entre os incorporados na publicação.

O documento, que não traz nenhuma orientação metodológica geral, apresenta no início de cada capítulo uma breve introdução, informando o total de programas, objetivos e iniciativas relacionados com cada tema. Em 2012, foi lançado um relatório de monitoramento, que por sua vez incluía o acompanhamento descritivo dos programas, objetivos e metas, ou seja, um relato sobre a execução no período. Cabe destacar que foram consideradas como metas diretrizes de ação sem necessariamente constar quantificação e prazo, o que permitiu incluir no monitoramento amplo leque de informaçóes relevantes, mas assistemáticas.

O relatório ainda abarcou um acompanhamento orçamentário que, ao agregar tanto açôes orçamentárias específicas, como programas universais com impacto indireto sobre a população negra, envolveu uma relação que extrapola o que se pode considerar efetivamente açóes afirmativas, de promoção da igualdade racial ou de enfrentamento ao racismo, nos termos anteriormente discutidos.

Posteriormente, na seção inicialmente dirigida para a Igualdade Racial e comunidades quilombolas, foram incorporados novos públicos - os povos e as comunidades tradicionais -, o que reduz a já comprometida análise específica quanto ao tema racial.

Posteriormente, o Ministério do Planejamento lançou sistema de acompanhamento do PPA em seu site (PPA mais Brasil), em que se pode visualizar o relato dos gestores para as iniciativas e metas relacionadas a cada tema, conforme a formulação inicial do documento Agendas Transversais. No entanto, embora em um sistema relativamente amigável, não se superam os limites de acompanhamento ora enunciados. Podem-se verificar relatos importantes sobre a trajetória das açóes ligadas à questão racial no período; mas, se de partida não se estabeleceram compromissos, não há como avaliar o desenvolvimento da política a contento. Ademais, nem em termos dos produtos das açóes executadas os resultados aparecem de forma clara e sistematizada. Por fim, não há, para o usuário, integração com o sistema de orçamento. ${ }^{80}$

Na Lei Orçamentária Anual (LOA) 2013, o número de açôes orçamentárias já reduzidas que caracterizou o PPA atual foi ainda mais condensado. Por exemplo, a ação "Implantação de Equipamentos Culturais da Cultura Afro-Brasileira" foi absorvida por uma ação denominada "Implantação de Equipamentos Culturais", que serve a diferentes áreas do MINC. 
No entanto, foi introduzido novo elemento que pode contribuir para o monitoramento do orçamento: trata-se do Plano orçamentário (PO):

O PO é uma identificação orçamentária, de caráter gerencial (não constante na LOA), vinculada à açáo orçamentária, que tem por finalidade permitir que tanto a elaboraçáo do orçamento quanto o acompanhamento físico e financeiro da execução ocorram num nível mais detalhado do que o do subtítulo (localizador de gasto) da ação (Brasil, 2013b, p. 43).

Com o PO, podem-se detalhar produtos intermediários da ação; etapas de projeto e açóes prioritárias (chamadas de Mecanismo de acompanhamento intensivo). No Manual para LOA 2015, consta uma outra finalidade, qual seja, a desagregaçáo de estruturas administrativas descentralizadas. Todo recurso da ação orçamentária não precisa estar necessariamente distribuído nos POs, ou seja, nem sempre a soma dos POs corresponde ao total da ação orçamentária.

No PO, devem ser apresentados os detalhamentos da ação orçamentária, prejudicados pelo processo de aglutinaçáo. Nele, o gestor deve prever e atualizar a execução física e financeira desagregada. Procura-se nessa tentativa agregar a facilidade de um orçamento mais flexível com o detalhamento e transparência das informaçóes. Contudo, como se trata de um controle gerencial, a possibilidade de alteração nos compromissos assumidos é bem maior do que aqueles consolidados na peça orçamentária, que exigem tramitação legislativa.

Diante desse novo recurso, para identificar outras açóes orçamentárias relacionadas com a promoção da igualdade racial, foi realizada uma busca no Sistema Integrado de Planejamento e Orçamento do Brasil (SIOP), nos campos "açáo orçamentária" e "plano orçamentário", usando palavras-chaves. ${ }^{81}$ A tabela 7 sintetiza as açôes orçamentárias identificadas.

A tabela 7 demonstra o potencial de análise que o "Plano orçamentário" pode trazer, se for bem preenchido e bem controlado, a despeito da possibilidade de maior flexibilização dos compromissos. ${ }^{82}$ Nesse sentido, a ação do MDA - Apoio ao Desenvolvimento Sustentável das Comunidades Quilombolas, Povos Indígenas e Povos e Comunidades Tradicionais -, serve como exemplo ao distinguir metas para cada grupo atendido. Por sua vez, as ações do MMA e do MEC não utilizam a ferramenta para explicitar os recursos gastos com cada grupo de beneficiários, mantendo o processo de aglutinação de ações, o que dificulta a transparência. O orçamento da Seppir foi considerado separadamente na tabela 8.

81. Racial, afrodescendente, negro, afrodescendente, afirmativa, quilombo, africana.

82. Há um recurso no código identificador do PO (Área Temática) indicado no MTO 2015, mas ainda não utilizado, que pode servir como um filtro no mapeamento das ações voltadas a determinada área. 


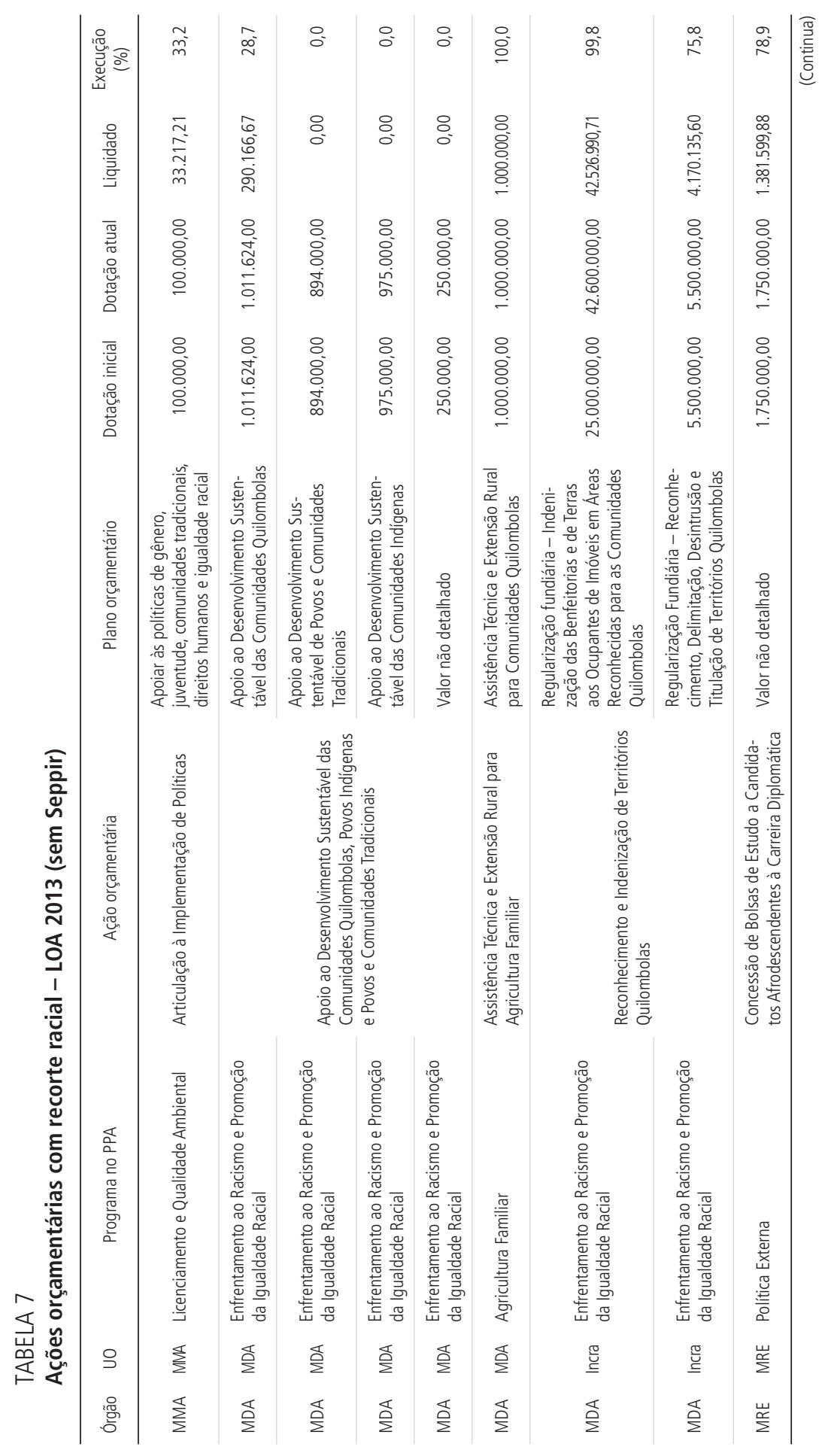




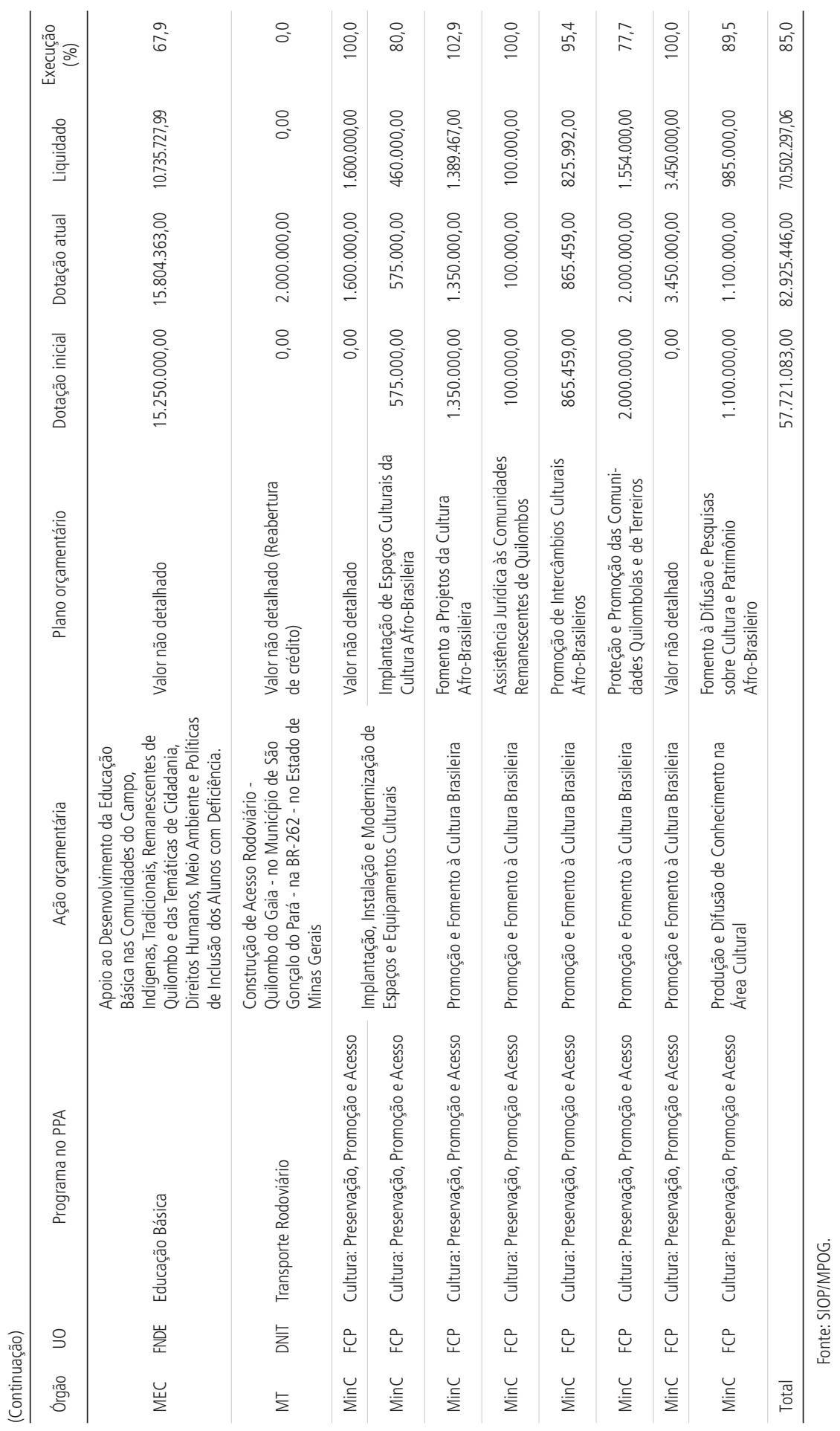


TABELA 8

Execução orçamentária da Seppir (2013)

(Em mil)

\begin{tabular}{|c|c|c|c|c|}
\hline Programas e ações dos órgãos selecionados & Dotação inicial & $\begin{array}{c}\text { Autorizado } \\
\text { (lei + créditos) }\end{array}$ & Liquidado & $\begin{array}{c}\text { Nível de } \\
\text { execução (\%) }\end{array}$ \\
\hline & (A) & (B) & (C) & $(D-C / B)$ \\
\hline $\begin{array}{l}\text { Secretaria de Políticas de Promoção } \\
\text { da Igualdade Racial - total }\end{array}$ & 54.660 & 56.139 & 34.546 & 61,54 \\
\hline Enfrentamento ao racismo e promoção da igualdade racial & 24.136 & 24.836 & 9.756 & 39,28 \\
\hline $\begin{array}{l}\text { Fomento a ações afirmativas e outras iniciativas para } \\
\text { a promoção da igualdade racial }{ }^{1}\end{array}$ & 11.811 & 11.811 & 4.491 & 38,03 \\
\hline $\begin{array}{l}\text { Fomento ao desenvolvimento local para comunidades } \\
\text { remanescentes de quilombos e outras comunidades } \\
\text { tradicionais }{ }^{2}\end{array}$ & 12.325 & 13.025 & 5.265 & 40,42 \\
\hline Programa de gestão e manutenção & 30.524 & 31.303 & 24.790 & 79,19 \\
\hline \multicolumn{5}{|c|}{$\begin{array}{l}\text { Fonte: Câmara dos Deputados. } \\
\text { Notas: }{ }^{1} \text { Formulação e implementação de políticas e/ou apoio a iniciativas governamentais e não-governamentais de formação } \\
\text { e capacitação de agentes públicos e profissionais da iniciativa privada, levantamento e construção de cadastro de } \\
\text { programas de ações afirmativas, promoção de eventos, confecção e divulgação de conteúdos educativos e/ou } \\
\text { de comunicaçãa de ações afirmativas e valorização da pluralidade etnicorracial, visando promover a criação e imple- } \\
\text { mentação de programas de enfrentamento às desigualdades raciais e de ações afirmativas voltadas à valorização da } \\
\text { pluralidade etnicorracial e à inclusão socioeconômica, política e cultural da população negra em especial, e de outros } \\
\text { grupos historicamente discriminados. } \\
{ }^{2} \text { Apoio técnico, estudos de viabilidade econômica, capacitação de agentes de apoio e da comunidade local e apoio a } \\
\text { projetos de fortalecimento institucional envolvendo as organizações representativas das comunidades Quilombolas e } \\
\text { de outras comunidades tradicionais. }\end{array}$} \\
\hline
\end{tabular}

As atividades finalísticas da pasta foram agregadas em duas grandes ações orçamentárias. Até mesmo a Seppir não utilizou o recurso dos POs para detalhar os produtos intermediários de suas ações finalísticas. Somente no Programa de Gestão há este detalhamento, o que permitiu identificar duas atividades importantes e voltadas para estruturação da política: monitoramento e avaliação de políticas e programas de promoção da Igualdade Racial e apoio a conselhos e organismos governamentais de promoção da Igualdade Racial, com dotaçôes iniciais respectivamente de R \$ 164 mil e R \$ 3,273 milhóes.

No que tange à execução orçamentária da Seppir para o período, embora a execução global seja de $61,5 \%$ dos recursos, verifica-se que as açóes finalísticas estão bem abaixo desta marca, ainda que não tenham sofrido contingenciamento, como ocorreu em exercícios anteriores. ${ }^{83}$

Por fim, o gráfico 1 apresenta a trajetória do orçamento da Seppir e parece sinalizar uma recuperação em relação aos últimos dois anos, tanto em termos de nível de execução, como de montante efetivamente liquidado.

83. Conforme relatório de gestão da Seppir (2014), não houve contingenciamento das ações finalísticas nesse exercício; os limites orçamentários teriam se restringido à ação "Administração da Unidade". 
Espera-se que o uso intensivo e adequado do recurso PO possibilite maior transparência e sistematização das informações orçamentárias mais atinentes à questão racial nos próximos exercícios.

GRÁFICO 1

Trajetória orçamentária da Seppir

(Em \%)

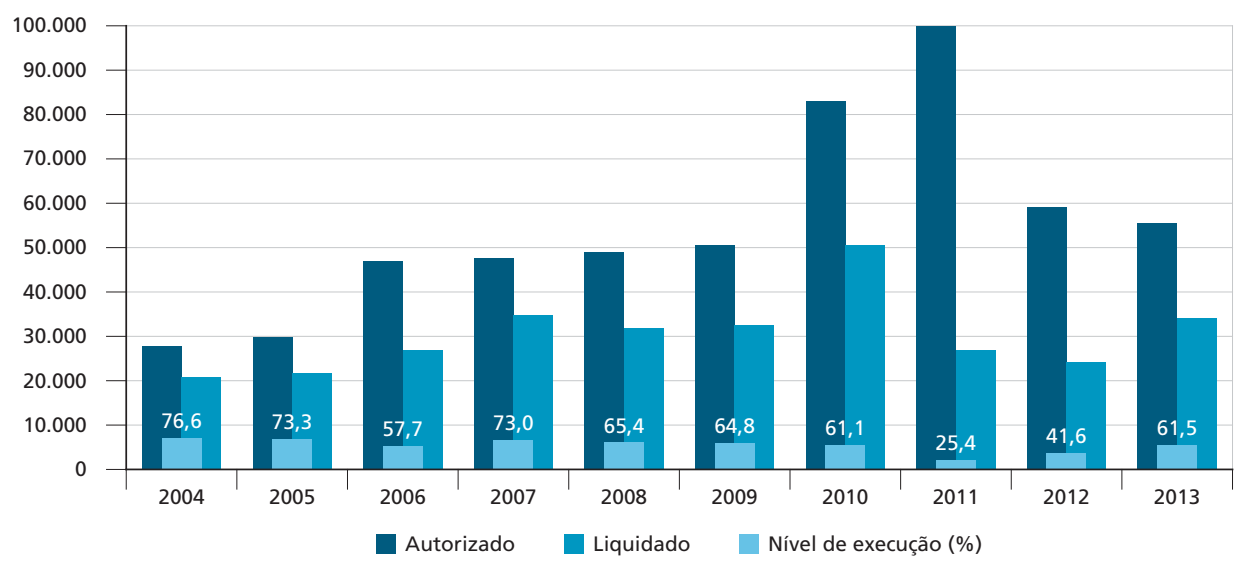

Fonte: Siga Brasil e IPCA (2013).

\section{DESAFIOS}

O ano de 2014 encerra não apenas o ciclo de uma década de criação da Seppir, em 2013, mas também o primeiro governo Dilma Rousseff. Nestes dois períodos sobrepostos, houve muitos avanços para a política de igualdade racial. A promoçáo da Igualdade racial foi declarada como uns dos objetivos prioritários do governo nos últimos Planos Plurianuais. Medidas de grande relevância para a população negra se concretizaram nos últimos quatro anos, a exemplo das legislaçóes de cotas no ensino superior e na administração pública. Porém, estes avanços são ainda pequenos em relaçấo às discrepâncias abissais existentes no Brasil.

A aprovaçáo da Lei no 12.711/12 (Lei de Cotas para ingresso em IES) e da Lei no 12.990/14 (Lei de Cotas para negros em Concurso Público Federal) representa o início de marcos legais fundamentais em direção à promoção da equidade. Porém, também representam um desafio na medida em que discursos racistas como o da meritocracia, da miscigenação, entre outros - se reinventam para garantir a manutenção das disparidades raciais no Brasil.

O crescimento dos casos de racismo e de violência generalizada contra a população negra, sobretudo sua juventude, desafia toda a estrutura de funcionamento do Estado brasileiro e suas formas clássicas de combate à violência. A tentativa de oferecer segurança à populaçáo, como demonstrado neste capítulo, integra uma geopolítica 
urbana que expressa um conflito complexo de territorialidades, distinguindo os que devem ser protegidos e os que devem ser vigiados, mediada por uma tecnologia de poder que vem servindo como argamassa para a legitimação da militarização da questão urbana. A formação de uma sociedade securitária dominada por uma fobia paranóica coloca o corpo negro em estado permanente de suspeiçáo e controle.

Estes fatos corriqueiros, esta subjetividade do medo dá forma e legitimação à ascensão do Estado penal no mundo contemporâneo, em que cabe à polícia coibir a violência que o sistema econômico, político e social engendra. A pena e a puniçáo funcionam nesse esquema como economia política que produz inquisição, programas, discursos, políticas públicas e estigmas sociais (Batista, 2012). Neste cenário de recrudescimento da violência sistêmica, de militarizaçáo de conflitos, o racismo ganha novo escopo institucional, reproduzido como elemento intrínseco às principais políticas urbanas atualmente em curso nas grandes metrópoles brasileiras, em que a segurança é mais uma mercadoria oferecida na prateleira de bens e serviços a serem consumidos.

Enquanto a população negra é submetida à escalada de violência engendrada pelos próprios aparelhos de Estado, a ideia de transversalidade que estrutura as políticas raciais permanece apenas como discurso oficial. Uma década de política de igualdade racial não foi suficiente para garantir a inserção da pauta racial como um dos elementos nucleadores das políticas universais, garantindo a ela a mesma centralidade que o racismo exerce na produção das desigualdades sociais. Ainda que o discurso de transversalidade da política esteja presente, inclusive nos documentos oficiais e nos enunciados de diversos programas, sua efetividade carece de poder efetivamente atribuído a quem pode torná-lo concreto.

Eis o cerne da mudança necessária para real inserção da questão racial na agenda governamental, superando o voluntarismo em compromisso político que possibilite tornar eficazes os diversos marcos legais em vigor para o tema. E, para ilustrar, podem-se citar políticas pactuadas e institucionalizadas que ainda estáo longe de estar plenamente implementadas, como a educação para as relaçóes étnico-raciais, a regularização fundiária de territórios quilombolas e a política nacional de saúde integral da população negra.

Por sua vez, para a ampliação das ações afirmativas para a população negra, se faz necessário dotar os órgãos e instâncias dedicadas a elas de mais autonomia em termos decisórios e materiais. Já passou o tempo dos projetos-piloto, de baixo orçamento e limitada capilaridade. As ações afirmativas precisam de outro escopo.

Por fim, essas mudanças de patamar não são exequíveis sem a redefinição de estruturas de governo que dialoguem com os processos de políticas públicas, da sua formulação até a avaliação dos programas governamentais, para implementar a igualdade racial em sua dinâmica. Garantir que, em todas essas fases, a questâo racial se operacionalize é um desafio técnico e político de grande monta, mas inescusável para avançarmos nesta tão importante agenda. 


\section{REFERÊNCIAS}

ARAUJO, Marianna; CASTRO, Vitor. Maré de terror. APública, 1o jul. 2013. Disponível em: <http://goo.gl/pgMT8l>.

ARRUTI, José Mauricio Andion. A emergência dos "remanescentes": notas para o diálogo entre indígenas e quilombolas. Revista Mana, Rio de Janeiro, v. 3, n. 2, out. 1997. Disponível em: <http://goo.gl/vhQ0SG>. Acesso em: 6 set. 2014.

AZEVEDO, Lena. Operação Limpeza. APública, 15 jul. 2014. Disponível em: $<$ http://goo.gl/GpLoQh>.

BARROSO, Luís Roberto. Ação popular e ação civil pública: aspectos comuns e distintivos. Cadernos de direito constitucional e ciência política, n. 4, p. 233-241, 1993.

BASTHI, Angélica. Breve reflexão sobre Pelé e a experiência negra no futebol brasileiro. CAMPOS, Flavio; ALFONSI, Daniela (Orgs.). Futebol objeto das ciências humanas. São Paulo: Leya, 2014.

BATISTA, Vera Malaguti. Na periferia do medo. In: ESTADOS GERAIS DA PSICANÁLISE, 2., 2003, Rio de Janeiro. Anais... Rio de Janeiro: EGP, 2003. Disponível em: <http://goo.gl/8JjJ0d>. Acesso em: 7 ago. 2014.

Adesão subjetiva à barbárie. In: (Org.). Loic Wacquant e a questão penal no capitalismo neoliberal. Rio de Janeiro: Revan, 2012. Disponível em: <http://goo.gl/xlg7dg>.

BETTO, Frei. Países que reduziram a maioridade penal não diminuíram a violência. Portal Fórum, 16 abr. 2014. Acesso 10 maio 2014. Disponível em: <http://goo.g//lCjeoz>.

BRASIL. Decreto-lei no 898, de 29 de setembro de 1969. Define os crimes contra a segurança nacional, a ordem política e social, estabelece seu processo e julgamento e dá outras providências. Diário Oficial da Uniáo, Brasília, set. 1969. Disponível em: <http://goo.gl/jOvKZS>.

Lei no 7347, de 24 de julho de 1985. Disciplina a ação civil pública de responsabilidade por danos causados ao meio-ambiente, ao consumidor, a bens e direitos de valor artístico, estético, histórico, turístico e paisagístico (vetado) e dá outras providências. Diário Oficial da Uniáo, Brasília, jul. 1985.

Senado Federal. PLS - Projeto de lei do Senado, no 114 de 1997. Dispóe sobre a ação civil destinada ao cumprimento da obrigação de fazer ou de não fazer, para a preservação da honra e dignidade de grupos raciais, étnicos e religiosos. Brasília: Senado Federal, 1997.

Constituição. Constituiçáo da República Federativa do Brasil. Brasília: Senado Federal, 1998. 
Lei no 10.826 , de 22 de dezembro de 2003.Dispóe sobre registro, posse e comercialização de armas de fogo e muniçáo, sobre o Sistema Nacional de Armas Sinarm, define crimes e dá outras providências. Diário Oficial da Uniáo, Brasília, dez. 2003. Disponível em: <http://goo.gl/Vc0Shz>.

Emenda constitucional no 45, de 30 de dezembro de 2004. Altera dispositivos dos Arts. 5-, 36, 52, 92, 93, 95, 98, 99, 102, 103, 104, 105, 107, $109,111,112,114,115,125,126,127,128,129,134$ e 168 da Constituição Federal, e acrescenta os Arts. 103-A, 103B, 111-A e 130-A, e dá outras providências. Brasília, Diário Oficial da União, Brasília, dez. 2004.

Lei no 11635, de 27 de dezembro de 2007. Institui o Dia Nacional de Combate à Intolerância Religiosa. Diário Oficial da Uniáo, Brasília, 2007a. Disponível em: <http://goo.gl/mLgQhI>.

Decreto no 6040, de 7 de fevereiro de 2007. Institui a Política Nacional de Desenvolvimento Sustentável dos Povos e Comunidades Tradicionais. Diário Oficial da União, Brasília, fev. 2007b. Disponível em: <http://goo.gl/0qXbLf>.

. Lei no 12.035 , de $1^{\circ}$ de outubro de 2009. Institui o Ato Olímpico, no âmbito da administração pública federal, com a finalidade de assegurar garantias à candidatura da cidade do Rio de Janeiro a sede dos Jogos Olímpicos e Paraolímpicos de 2016 e de estabelecer regras especiais para a sua realização, condicionada a aplicação desta Lei à confirmação da escolha da referida cidade pelo Comitê Olímpico Internacional. Diário Oficial da Uniáo, Brasília, 1ํout. 2009. Disponível em: <http://goo.gl/9Z7ON4>.

Lei no 12288 , de 20 de julho de 2010. Institui o Estatuto da Igualdade Racial; altera as Leis $\mathrm{n}$ os 7716 , de 5 de janeiro de 1989, 9029, de 13 de abril de 1995, 7347, de 24 de julho de 1985, e 10778, de 24 de novembro de 2003. Diário Oficial da União, Brasília, 2010a.

Decreto no 7.234, 19 de julho de 2010, que institui o Programa Nacional de Assistência Estudantil (Pnaes). Diário Oficial da União, Brasília, jul. 2010b. Disponível em: <http://goo.gl/2PZcRM>.

. PLS - Projeto de Lei do Senado, no 728, de 2011. Define crimes e infraçóes administrativas com vistas a incrementar a segurança da Copa das Confederaçóes FIFA de 2013 e da Copa do Mundo de Futebol de 2014, além de prever o incidente de celeridade processual e medidas cautelares específicas, bem como disciplinar o direito de greve no período que antecede e durante a realização dos eventos, entre outras providências. Brasilia: Senado Federal, 2011a. Disponível em: <http://goo.gl/TmAwpzu>.

PEC - Proposta de emenda à Constituição, no 31 de 2011. Acrescenta o Art. 159-A à Constituição Federal, para determinar a compensação financeira 
pela Uniáo aos demais entes federados, e pelos Estados aos respectivos municípios, nas hipóteses que especifica. Brasília: Senado Federal, 2011b.

PEC - Proposta de emenda à Constituição, no 99 de 2011. Acrescenta ao Art. 103, da Constituiçáo Federal, o inciso X, que dispóe sobre a capacidade postulatória das Associaçôes Religiosas para propor ação de inconstitucionalidade e ação declaratória de constitucionalidade de leis ou atos normativos, perante a Constituiçẫo Federal. Brasília: Câmara dos Deputados, out. 2011c. (Em aprovação). Disponível em: <http://goo.gl/aR44kV>.

- Ministério do Planejamento, Orçamento e Gestáo. Secretaria de Orçamento Federal; Secretaria-Geral da Presidência da República, Secretaria Nacional de Articulação Social. Plano Mais Brasil, mais desenvolvimento, mais igualdade, mais participaçáo PPA: 2012-2015 - agendas transversais. Brasília: MP/SPI, 2011 d. Disponível em: <http://goo.gl/qc1SBm>. Acesso em: 10 ago. 2014.

Lei no 12.663 , de 5 de junho de 2012. Dispóe sobre as medidas relativas à Copa das Confederaçóes FIFA 2013, à Copa do Mundo FIFA 2014 e à Jornada Mundial da Juventude 2013. Diário Oficial da Uniáo, Brasília, jun. 2012a. Disponível em: <http://goo.gl/oiOuzZ>.

Lei no 12.711 , de 29 de agosto de 2012. Dispóe sobre o ingresso nas universidades federais e nas instituiçôes federais de ensino técnico de nível médio e dá outras providências. Diário Oficial da Uniáo, Brasília, ago. 2012b. Disponível em: <http://goo.gl/BBs3tV>.

. Ministério da Defesa. Portaria Normativa no 3.461/MD, de 19 de dezembro de 2013. Dispóe sobre a publicaçáo "Garantia da Lei e da Ordem". Diário Oficial da Uniấo, Brasília, dez. 2013a.

. Ministério do Planejamento, Orçamento e Gestão. Secretaria de Orçamento Federal. Manual técnico de orçamento. Brasília: MTO/SOF, 2013b. Disponível em: <http://goo.gl/bwHteF>.

Lei no 12.966 , de 24 abril de 2014 . Altera a Lei no 7.347 , de 24 de julho de 1985 (Lei da Ação Civil Pública), para incluir a proteçâo à honra e à dignidade de grupos raciais, étnicos ou religiosos. Diário Oficial da Uniáo, Brasília, jul. 2014a.

Lei no 13.022 , de 8 de agosto de 2014. Dispóe sobre o Estatuto Geral das Guardas Municipais. Diário Oficial da Uniáo, Brasília, ago. 2014b. Disponível em: $<$ http://goo.gl/TbAvSw>.

. Senado Federal. Secretaria de Gestão de Informação e Documentação. Ato da Comissão Diretora no 7, 2014. Brasília: Senado Federal, maio 2014c. Disponível em: <http://goo.gl/moHI7n>. 
Ministério do Planejamento, Orçamento e Gestão. Secretaria de Gestão

Pública. Boletim estatístico de pessoal e informaçóes organizacionais, v. 19, n. 219, jul. 2014d. Disponível em: <http://goo.gl/Jw1A1F>.

CAMPOS, Flavio de. Arquitetura da exclusão: apontamentos para a inquietação com o conforto. In: CAMPOS, Flavio; ALFONSI, Daniela (Orgs.). Futebol objeto das ciências humanas. São Paulo: Leya, 2014a.

CAMPOS, Luis Augusto. Socialismo moreno, conservadorismo pálido? Cor e recrutamento de candidaturas nas duas maiores cidades brasileiras. In: ENCONTRO DA ABCP. ÁREA TEMÁTICA: ELEIÇÔES E REPRESENTAÇÃO POLÍTICA, 9., 2014b, Brasília. Anais... Brasília: ABCP, 2014b. Disponível em: <http://goo.gl/rIJsTR>.

CAMPOS, Luiz Augusto; MACHADO, Carlos. A cor e o sexo da política: composição das câmaras federais e estaduais. Rio de Janeiro: Gemaa, 2014. p. 1-21. (Textos para Discussão Gemaa, n. 7).

CAMPOS, Luiz Augusto; FERES JÚNIOR, João; DAFLON, Verônica Toste. Administrando o debate público: O Globo e a controvérsia em torno das cotas raciais. Revista Brasileira de Ciência Política, Brasília, n. 11, maio/ago. 2013. Disponível em: <http://goo.gl/klzl0G>. Acesso em: 17 jul. 2014.

CARVALHO, José Jorge de. Mapa das açóes afirmativas no Brasil. José Jorge de Carvalho. Brasília: INCTI, maio 2012. Disponível em: <www.inctinclusao.com.br>. Acessado em: 09 out. 2013.

CHAUÍ, Marilena. Brasil: mito fundador e sociedade autoritária. São Paulo: Fundação Perseu Abramo, 2000. Disponível em: <http://goo.gl/Z0mF22>.

CICONELLO, Alexandre. O orçamento das políticas federais de promoçáo da igualdade racial e combate ao racismo: baixa prioridade e execuçấo. Brasília: INESC, 2012. (Nota Técnica, n. 179). Disponível em: <http://goo.gl/fbS8gm>.

CNJ - CONSELHO NACIONAL DE JUSTIÇA. Censo do Poder Judiciário: Vide - Vetores Iniciais e Dados Estatísticos. Brasília: CNJ, 2014a. Disponível em: <http://goo.gl/osulT8>.

Departamento de Monitoramento e Fiscalização do Sistema Carcerário e do Sistema de Execução de Medidas Socioeducativas. Novo diagnóstico de pessoas presas no Brasil. Brasília: DMF, jun. 2014b. Disponível em: <http://goo.gl/194DUT>. Acesso em: 10 set. 2014.

COSTA, Leda Maria da. Alteridades imaginadas: as narrativas da derrota e os vilóes da seleçấo brasileira em Copas do Mundo. Mídia e identidade nacional. Disponível em: <http://goo.gl/iXK3th>. Acesso em: 10 jul. 2014. 
DAFLON, Verônica Toste, FERES JUNIOR, João, MORATELLI, Gabriela. Levantamento das políticas de açáo afirmativa 2014: evolução temporal e impacto da Lei no 12.711 sobre as universidades federais. São Paulo; Rio de Janeiro: IESP-UERJ, 2014. n. 4, p. 1-10. Disponível em: <http://goo.gl/9fxYPT>.

DECISÃO considera MS via inadequada para discutir cotas em concursos. STF Notícias, 14 ago. 2014. Disponível em: <http://goo.gl/SrBDmk>.

DIAP-DEPARTAMENTO INTERSINDICAL DEASSESSORIA PARLAMENTAR. Radiografia do novo Congresso: legislatura 2011-2015. Brasília: Diap, dez. 2010. (Série Estudos Políticos, a. 5). Disponível em: <http://goo.gl/h0sJmW>.

ESPÍRITO SANTO. Tribunal de Justiça. Relatório: ação de inconstitucionalidade $\mathrm{n}^{\mathrm{o}}$ 100070023542. Vitória: TJES, 23 set. 2010. Disponível em: <http://goo.gl/xgkFCo>.

FARIAS, Jesualdo Pereira. Fórum Assessor da Andifes. Brasília: Fonaprace, 15 abr. 2014. Disponível em: <http://goo.gl/F4DNVg>.

FBSP - FÓRUM BRASILEIRO DE SEGURANÇA PÚBLICA. Anuário Brasileiro de Segurança Pública 2013. São Paulo: FBSP, 2013. Disponível em: <http://www. forumseguranca.org.br/estatistica/dados-criminais>. Acesso em: 16 out. 2014.

FGV - FUNDAÇÃO GETÚLIO VARGAS. Indicadores socioeconômicos nas UPPs da cidade do Rio de Janeiro. FGV Projetos, Rio de Janeiro, n. 17, 2012. Disponível em: <http://goo.gl/1Jxv2T>. Acesso em: 16 set. 2014.

FILHO, Mario. O negro no futebol brasileiro. Rio de janeiro: Mauad, 2010.

FRANCO JUNIOR, Hilário. A dança dos deuses: futebol, cultura, sociedade. São Paulo: Companhia das Letras, 2007.

FREYRE, Gilberto. Foot-ball mulato. Diário de Pernambuco, 18.06.1938. Sociologia, Rio de Janeiro, v. 2, p. 431-433, 1973.

GARCIA, Ronaldo Coutinho. PPA: o que não é e o que pode ser. Políticas sociais: acompanhamento e análise, Brasília, n. 20, artigo especial, 2012. Disponível em: $<$ http://goo.gl/1JJvqY>. Acesso em: 26 jan. 2015.

GRANJEIA, Jualianna. Professor “dá uma aula” de Revolução Francesa para não ser linchado. O Globo, 1o jul. 2014.

HOLANDA, Sérgio Buarque de. Raízes do Brasil. 26. ed. São Paulo: Companhia das Letras, 1995. Disponível em: <http://goo.gl/8elDtj>.

HOLLANDA, Bernardo Borges Buarque de. O fim do estádio nação? Notas sobre a construção e a remodelagem do Maracanã para a Copa de 2014. In: CAMPOS, Flavio; ALFONSI, Daniela (Orgs.). Futebol objeto das ciências humanas. São Paulo: Leya, 2014. 
IBGE - INSTITUTO BRASILEIRO DE GEOGRAFIA E ESTATISTICA. PNAD: Pesquisa Nacional por Amostra de Domicílio 2013.

INESC - INSTITUTO DE ESTUDOS SOCIOECONÔMICOS. Perfil dos candidatos às eleiçóes 2014: sub-representação de negros, indígenas e mulheres desafio à democracia. Brasília: Inesc, set. 2014. Disponível em: <http://goo.gl/Y9ptrd> . Acesso em: 19 set. 2014.

IPEA - INSTITUTO DE PESQUISA ECONÔMICA APLICADA. Retrato das desigualdades de gênero e raça. Brasília: Ipea, 2011. Disponível em: <http:// www.ipea.gov.br/retrato/\#>.

ISAIA, Artur César. A umbanda: as imagens do inimigo no discurso católico de meados do século XX. [S.l.]: ABHR, [s.d.]. Disponível em: <http://bmgil.tripod. com/iac29.html>. Acesso em: 26 jan. 2015.

IKAWA, Daniela. Açóes Afirmativas em Universidades. In: LEWANDOWSKI, R. (Org.). Arguição de descumprimento de preceito fundamental 186: voto. Brasília: STF, 2012. Disponível em: <http://goo.gl/LxWVyT>. Acesso em: 10 set. 2014.

LAESER - LABORATÓRIO DE ANÁLISES ECONÔMICAS, HISTÓRICAS, SOCIAIS E ESTATÍSTICAS DAS RELAÇŌES RACIAIS. Eleições 2014 e as propostas para a igualdade racial. Tempo em Curso, v. 6, n. 8, a. 6, ago. 2014. Disponível em: <http://goo.gl/OtIB0e>. Acesso em: 23 set. 2014.

LEITE, Marcelo. Oitenta e dois porcento dos paulistanos são contra "rolezinho", diz pesquisa Datafolha. Folha de Sáo Paulo, São Paulo, 9 mar. 2015. Disponível em: <http://goo.gl/fzBTLf>.

LOPES, Felipe Tavares Paes. Dimensões ideológicas do debate público acerca da violência no futebol brasileiro. Revista Brasileira de Educação Física e Esporte, São Paulo, v. 27, n. 4, p. 597-612, out./dez. 2013. Disponível em: <http://goo.gl/ITfylk>. Acesso em: 15 ago. 2014.

MARTINS, José de Souza. As condiçôes do estudo sociológico dos linchamentos no Brasil. Revista Estudos Avançados, São Paulo, v. 9, n. 25, p. 295-310, set./dez., 1995. Acesso em: 5 jul. 2014.

MELGAÇO, Lucas. Securizaçáo da vida urbana: da psicoesfera do medo a tecnoesfera da segurança. 2010. Tese (Doutorado) - Universidade de São Paulo, São Paulo, 2010. Disponível em: <http://goo.gl/DGBvxa>. Acesso em: 10 ago. 2014.

MENDES, Priscilla. Senado terá cota de $20 \%$ para negros em concursos públicos, diz Renan. G1, 13 maio 2014. Disponível em: <http://goo.gl/9MfpzW>. Acesso em: 15 set. 2014. 
MERLINO, Tatiana; CASTOR, Caio. A pacificação violenta da Maré. Brasil de Fato, Rio de Janeiro, 27 maio 2014. Disponível em: <http://goo.gl/V0qSI2>.

MOURA, Tatiana Whately et al. Mapa da Defensoria Pública no Brasil. Brasília: Ipea; Anadep, 2013.

MS pede cotas raciais em concursos do Judiciário e Legislativo da União. Notícias STF, 14 jul. 2014. Disponível em: <http://goo.gl/rh0DG2>.

OLIVEIRA, Nelma Gusmão de. A produção da cidade através do espetáculo esportivo: quando a exceção se torna regra. @metropolis, n. 13, a. 4, p. 10-19, jun. 2013. Disponível em: <http://goo.gl/XpB925>. Acesso em: 10 out. 2014.

OSÓRIO, R. G. Desigualdades raciais e de gênero no serviço público civil: programa de fortalecimento institucional para a igualdade de gênero e raça, erradicação da pobreza e geração de emprego (GRPE). Brasília: [S.I.], 2006. (Cadernos GRPE, n. 2).

RESENDE, Igor. Aranha chegou a apanhar e ser detido por engano mas "perdoou" policiais. ESPN, 29 ago. 2014. Disponível em: <http://goo.gl/OH6tby>.

RIO DE JANEIRO. Lei no 6717, de 18 de março de 2014. Proíbe o ingresso ou permanência de pessoas utilizando capacete ou qualquer tipo de cobertura que oculte a face, nos estabelecimentos comerciais, públicos ou abertos ao público. Diário Oficial do Estado do Rio de Janeiro, Rio de Janeiro, mar. 2014a. Disponível em: <http://goo.gl/yeXQ8i>.

Processo no 0004747-33.2014.4.02.5101. Rio de Janeiro: MPF; PRRJ, 2014b. Disponível em: <http://goo.gl/VPbLtu>.

SALVADOR. Secretaria Municipal de Gestão. Processo seletivo simplificado no 04/2014/SEMGE, de 12 de setembro de 2014. Salvador: Secretaria Municipal de Gestâo, 12 set. 2014.

SANTOS, Irlan Simóes da Cruz. O público dos estádios: marcos históricos da atual elitização e arenização do futebol brasileiro. In: CONGRESSO DE CIÊNCIAS DA COMUNICAÇÃO NA REGIÁO NORDESTE JOÃO PESSOA, 16. João Pessoa. Anais... João Pessoa: Intercom, 15-17 maio 2014. Disponível em: $<$ http://goo.gl/4EebuV>. Acesso em: 10 set. 2014.

SEPPIR - SECRETARIA DE POLÍTICAS DE PROMOÇÃO DA IGUALDADE RACIAL. Relatório de gestão do exercício de 2013. Brasília: Presidência da República; SEPPIR, 2013.

SILVA, Josenilton Marques da; SILVA, Tatiana Dias. Igualdade racial. Políticas sociais: acompanhamento e análise, Brasília, n. 21, p. 421-480, 2013. Disponível em: $<$ http://goo.gl/NS9X4f>. 
SILVA, Tatiana D. O estatuto da igualdade racial. Rio de Janeiro: Ipea, 2012. (Texto para Discussão, n. 1712). Disponível em: <http://goo.gl/0LaQF3>.

SILVA, Tatiana D. et al. Planejamento e financiamento das políticas de igualdade racial: possibilidades para o Plano Plurianual 2012-2015. Brasília: Ipea, 2011. (Nota Técnica, n. 7). Disponível em: <http://goo.gl/y5Kv3R>. Acesso em: 26 jan. 2015.

SILVA, Tatiana Dias; SILVA, Josenilton M. da. Reserva de vagas para negros em concursos públicos: uma análise a partir do Projeto de Lei 6.738/2013. Brasilia: Ipea, 2014. (Nota Técnica, n. 17). Disponível em: <http://goo.gl//zmld2W>. Acesso em: 23 set. 2014.

SINHORETTO, Jacqueline; SILVESTRE, Giane; SCHLITTLER, Maria Carolina. Desigualdade racial e segurança pública em Sáo Paulo: letalidade policial e prisóes em flagrante. São Paulo: UFSCAR, 2 abr. 2014. Disponível em: <http://goo.gl/pHKDFP>. Acesso em: 5 jul. 2014.

SOARES, Antonio Jorge. História e invençâo de tradiçôes no campo do futebol. Revista Estudos Históricos, v. 13, n. 23, 1999. Disponível em: <http://goo.gl/Br0974>. Acesso em: 15 jul. 2014.

SOUZA, Marcelo Lopes de. Militarização da questão urbana. Revista Lutas Sociais, São Paulo, n. 29, p. 117-129, jul./dez., 2012. Disponível em: <http://goo.gl/ik4I0I> .

SOUZA, Taiguara Libano Soares. Constituiçáo, segurança pública e estado de exceção permanente: a biopolítica dos autos de resistência. 2010. Dissertação (Mestrado) - Pontíficia Universidade Católica do Rio de Janeiro, Rio de Janeiro, 2010. Disponível em: <http://goo.gl/ylzUvO>. Acesso em: 3 ago. 2014.

STF - SUPREMO TRIBUNAL FEDERAL. MS 33072: mandado de segurança (eletrônico). Relatora: Ministra Cármen Lúcia. Brasília: STF, 7 ago. 2014. Disponível em: <http://goo.gl/uLr0Np>. Acesso em: 15 set. 2014.

UNEGRO - UNIÁO DE NEGROS PELA IGUALDADE. Balanço eleitoral do voto étnico negro e presença dos negros no parlamento. Belo Horizonte: fev. 2011. Disponível em: <http://goo.gl/wGah8U>.

VAINER, Carlos B. Cidade de exceção: reflexões a partir do Rio de Janeiro. In: ENCONTRO NACIONAL DA ANPUR, 14., 2000, Rio de Janeiro. Anais... Rio de Janeiro: ANPUR, 23-27 maio 2011. Disponível em: <http://goo.gl/uMhmiu>. Acesso em: 13 ago. 2014.

VIEIRA, José Jairo. Consideraçóes sobre preconceito e discriminação racial no futebol brasileiro. Revista Teoria e Pesquisa, São Paulo, n. 42-43, p. 221-244, jan.-jul., 2003. Disponível em: < http://goo.gl//NvOXL>. Acesso em: 6 jul. 2014.

VOLPE; Ana Paula; SILVA, Tatiana D. Reserva de vagas para negros na administraçáo pública. Brasília: Ipea, 2014. (Relatório de Pesquisa). No prelo. 
WAISELFISZ, Julio Jacobo. Mapa da violência 2014: os jovens do Brasil. Rio de Janeiro: Flacso, 2014. Disponível em: <http://goo.gl/5s7833>. Acesso em: 20 set. 2014.

ZIGONI, Carmela. Democracia em disputa: como a Casa Grande se renovou nas eleiçôes 2014. Brasília: Inesc, 27 nov. 2014. Disponível em: <http://goo.gl/iiekLW>. Acesso em: 26 jan. 2015.

\section{BIBLIOGRAFIA COMPLEMENTAR}

ANCHIETA, Karen de Abreu. História da implantaçáo do sistema de cotas para negros na Universidade Estadual de Londrina - UEL (2000-2005). 2008. Dissertação (Mestrado) - Universidade Estadual de Londrina, Londrina, 2008.

BRASIL. Decreto no 6.096, de 24 de abril de 2007. Institui o Programa de Apoio a Planos de Reestruturação e Expansão das Universidades Federais - Reuni. Diário Oficial da Uniáo, Brasília, 2007a. Disponível em: <http://goo.gl/MzmH7D>.

Ministério da Educação. Reuni: reestruturação e expansão das universidades federais - diretrizes gerais. Brasilia: MEC, 2007b. Disponível em: <http://goo.gl/iDi2VO>.

Ministério da Educação. Portaria no 582, de 14 de maio de 2008. Disciplina a concessão de bolsas de pós-graduação do Reuni. Diário Oficial da Uniáo, Brasília, 14 maio 2008. Disponível em: <http://goo.gl/Elp8pM>.

Ministério da Educação. Análise sobre a Expansão das Universidades federais 2003-2012. Brasília: MEC, 2013a.

CASTRO, João Abrahão de; AQUINO, Luseni Maria C. de; ANDRADE, Carla Coelho de. Juventude e Políticas Sociais no Brasil. Brasília: Ipea, 2009.

CARVALHAS, Flávio; FERES JUNIOR, João; DAFLON, Verônica. O impacto da Lei de Cotas nos estados: um estudo preliminar. Rio de Janeiro: Gemaa, 2007. p. 1-17. (Textos para Discussão Gemaa, n. 1).

COELHO, Sintia Said; VASCONCELOS, Maria Celi Chaves. A criação das instituiçôes de ensino superior no Brasil: o desafio tardio na américa latina. In: COLÓQUIO INTERNACIONAL SOBRE GESTÃO UNIVERSITÁRIA NA AMÉRICA DO SUL, 9., Florianópolis, 2009. Anais... Florianópolis: Cigu, 25-27 nov. 2009. Disponível em: <http://goo.gl/PcehFh>.

FERES JUNIOR, João; DAFLON, Verônica; RAMOS, Pedro; MIGUEL, Lorena. Açóes afirmativas raciais no ensino superior público brasileiro: um panorama analítico. Cadernos de pesquisa, v. 43, n. 148, p. 302-327, jan.-abr. 2013.

GHIRALDELLI JR, Paulo. História da educaçáo. São Paulo: Cortez, 1999. 
GOMES, Joaquim B. Barbosa. Açáo afirmativa e princípio constitucional da igualdade: o direito como instrumento de transformação social - a experiência dos EUA. Rio de Janeiro: Renovar, 2001.

LOPES, Maria Auxiliadora; BRAGA, Maria Lúcia de Santana (Orgs). Acesso e permanência da populaçáo negra no ensino superior. Brasília: MEC; Unesco, 2007.

MUNANGA, Kabengele (Org.). Superando o racismo na escola. 2. ed. Brasília: MEC, 2005.

NASCIMENTO, Alexandre do. Movimentos sociais, educação e cidadania: um estudo sobre os cursos pré-vestibulares populares. 1999. Dissertação (Mestrado) Universidade do Estado do Rio de Janeiro, Rio de Janeiro, 1999. Disponível em: <http://goo.gl/pkCtr6>. Acesso em: 22 jul. 2014.

PIZA, Edith. Adolescência e racismo: uma breve reflexão. In: SIMPÓSIO INTERNACIONAL DO ADOLESCENTE, 1., 2005. Anais... [S.1.: s.n], maio 2000. Disponível em: <http://goo.gl/CZsxsZ>. Acesso em: 10 out. 2014.

RIO DE JANEIRO. Lei no 5346, de 11 de dezembro de 2008. Dispóe sobre o novo sistema de cotas pra o ingresso nas Universidades Estaduais e dá outras providências. Porto Alegre: Editora Armazém Digital, 2009.

SANTOS, Irlan Simōes da Cruz. Futebol: segurança ou controle social? Outras Palavras, 7 jul. 2012. Disponível em: <http://goo.gl/GxgyGQ>. Acesso em: 13 jun. 2014.

SANTOS, Jocélio Teles (Org). Cotas nas universidades: análises dos processos de decisão. Salvador: CEAO, 2012.

O impacto das cotas nas universidades brasileiras (2004-2012).

Salvador: CEAO, 2013. Disponível em: <http://goo.gl/ZuKo5t>. 


\section{APÊNDICE A}

QUADRO A.1

Normas vigentes sobre reserva de vagas para negros na administração pública (2014)

\begin{tabular}{|c|c|c|c|c|}
\hline \multicolumn{2}{|r|}{ Localização } & Início & Vagas reservadas & Legislação \\
\hline 1 & Governo federal & 2014 & $20 \%$ & Lei no 12.990/2014 \\
\hline 2 & Senado Federal & 2014 & $20 \%$ & Ato da Comissão Diretora no 7, de 2014 \\
\hline \multicolumn{5}{|c|}{ Estados } \\
\hline 3 & Paraná & 2003 & $10 \%$ & Lei ㄲo 14.274/2003 e Lei no 16.024/2008 \\
\hline 4 & Mato Grosso do Sul & 2008 & $\begin{array}{c}10 \% \\
\text { (e } 3 \% \text { para indígenas) }\end{array}$ & $\begin{array}{l}\text { Lei no 3.594/2008 (alterada pela Lei ㄲo 3.939/2010) e } \\
\text { Decreto no } 13.141 / 2011\end{array}$ \\
\hline 5 & Rio de Janeiro & 2011 & $20 \%{ }^{1}$ & Decreto no 43.007/2011 e Lei no 6.067/2011 \\
\hline 6 & Rio Grande do Sul & 2011 & $\begin{array}{l}\text { Reserva de vagas pro- } \\
\text { porcional à população } \\
\text { estadual aos negros } \\
\text { nos cargos públicos }\end{array}$ & $\begin{array}{l}\text { Lei no 13.694/2011 e Decreto no 48.724/2011 e Portaria PGE } \\
\text { no 15.703/2011 }\end{array}$ \\
\hline 7 & São Paulo & 2013 & $\begin{array}{l}\text { Pontuação diferenciada } \\
\text { com meta de } 35 \% 1,5,6\end{array}$ & $\begin{array}{l}\text { Lei Complementar no 1.259, 15/01/2015; } \\
\text { Decreto nํ 59.900, de 06/12/2013 }\end{array}$ \\
\hline 8 & Bahia & 2014 & $30 \%{ }^{7}$ & Decreto no $15.353 / 2014$ \\
\hline \multicolumn{5}{|c|}{ Municípios } \\
\hline 9 & Nova Iguaçu (RJ) & 2011 & $20 \%{ }^{1}$ & Decreto no 9.064/2011 \\
\hline 10 & Resende (RJ) & 2004 & $20 \%$ & Lei no 4.095/2004 \\
\hline 11 & Rio de Janeiro (RJ) & 2008 & $20 \%^{1,2}$ & Lei no 4.978/2008 e Lei no 5.401/2012 \\
\hline 12 & Vitória (ES) & 2004 & $30 \%$ & tei $n^{\circ}-6.225 / 2004$ e Decreto no-13.249/2007 \\
\hline 13 & Bebedouro (SP) & 2003 & $20 \%$ & Lei no 3.250/2003 \\
\hline 14 & Campinas (SP) & 2004 & $20 \%{ }^{2}$ & Lei no 1.2156/2004 \\
\hline 15 & Cubatão (SP) & 2002 & $20 \%$ & Lei no 2.782/2002 e Decreto no 8.356/2002 \\
\hline 16 & Embu das Artes (SP) & 2010 & $20 \%$ & Lei Complementar no 37/2010 \\
\hline 17 & Itatiba (SP) & 2005 & $25 \%^{3}$ & Lei no 3.798/2005 \\
\hline 18 & Itu (SP) & 2003 & $20 \%{ }^{3}$ & Lei no 391/2003 \\
\hline 19 & Ituverava (SP) & 2003 & $20 \%{ }^{3}$ & Lei $n=3.544 / 2003$ \\
\hline 20 & Jaboticabal (SP) & 2003 & $20 \%$ & Lei no 3.134/2003 \\
\hline 21 & Jundiaí (SP) & 2002 & $20 \%^{3,4}$ & $\begin{array}{l}\text { Lei no 5.745/2002 (alterada pelas Leis no 5.979/2002, } \\
\text { no 6.750/2006 e no } 7.209 / 2008 \text { ) e Decreto no } 18.667 / 2002 \text {. }\end{array}$ \\
\hline 22 & Limeira (SP) & 2004 & $20 \%$ & Lei no 3.691/2004 e Decreto no 109/2004 \\
\hline 23 & Matão (SP) & 2004 & $20 \%{ }^{3}$ & Lei no 3.576/2004 \\
\hline 24 & Piracicaba (SP) & 2002 & $20 \%{ }^{3}$ & Lei no 5.202/2002 (revogada) e Lei no 6.246/2008 \\
\hline 25 & Porto Feliz (SP) & 2011 & $20 \%{ }^{1}$ & Lei no 4.993/2011 \\
\hline 26 & Betim (MG) & 2005 & $15 \%$ & teis n-4.119/2005 e n-4.925/2009 \\
\hline 27 & Campos Altos (MG) & 2006 & $10 \%$ & Lei no 236/2006 \\
\hline
\end{tabular}




\begin{tabular}{|c|c|c|c|c|}
\hline \multicolumn{2}{|r|}{ Localização } & Início & Vagas reservadas & Legislação \\
\hline 28 & Caratinga (MG) & 2003 & & Lei $n-2.776 / 2003$ \\
\hline 29 & Eontagem (MG) & 2004 & $12 \%$ & Lei $n-3.829 / 2004$ e Lei n- $-4.310 / 2009$ \\
\hline 30 & Guaxupé (MG) & 2003 & $20 \% \%^{3,4}$ & Lei o 1.585/2003 \\
\hline 31 & Hbiá (MG) & $200 z$ & $20 \% 3,4$ & tei $10-1.686 / 200 z$ \\
\hline 32 & tuiz de Fora (MG) & $200 z$ & $20 \% 3,4$ & tei n-10.283/2002 e Resolução no-1.193/2004 \\
\hline 33 & Ericiúma(SC) & 2004 & $20 \%$ & tei Complementar n-32/2004 \\
\hline 34 & Arroio Grande (RS) & 2005 & $10 \%$ & tei $n^{\circ}-2.239 / 2005$ \\
\hline 35 & Bagé (RS) & 2007 & $20 \%$ & Lei no 3.938/2002 e Decreto no 17/2007 \\
\hline 36 & Cachoeira do Sul (RS) & 2004 & $30 \%$ & Lei ํㅗ 3.550/2004 e Lei no 4.018/2010 \\
\hline 37 & Caxias do Sul (RS) & 2005 & $10 \%$ & Lei no 6.377/2005 e Decreto no 13.146/2007 \\
\hline 38 & Montenegro (RS) & 2004 & $12 \%$ & Lei no $4.016 / 2004$ Lei no 4.038/2004 \\
\hline 39 & Pelotas (RS) & 2003 & $20 \%$ & Lei no 4.989/2003 (alterada pela Lei no 5.858/2011) \\
\hline 40 & Porto Alegre (RS) & 2003 & $12 \%$ & Lei Complementar no 494/2003 e Decreto no 14.288/2003 \\
\hline 41 & São Leopoldo (RS) & 2005 & $12 \%$ & $\begin{array}{l}\text { Lei no } 5.784 / 2005 \text { e Decreto } n \cong 4.415 / 2005 \text { (alterado pelo } \\
\text { Decreto } n=4.532 / 2006 \text { ) }\end{array}$ \\
\hline 42 & Viamão (RS) & 2009 & $44 \%{ }^{1}$ & Lei $n \cong 3.210 / 2004$ e Lei n 3.257/2004 \\
\hline 43 & Araucária (PR) & 2003 & $10 \%$ & Lei no 2.070/2009 e Decreto no 23.523/2010 \\
\hline 44 & Bituruna (PR) & 2003 & $10 \%$ & Lei Estadual no 14.274/2003 \\
\hline 45 & Colombo (PR) & 2007 & $10 \%$ & Lei no 1.005/2007 \\
\hline 46 & Guarapirama (PR) & 2003 & $10 \%$ & Lei Estadual no 14.274/2003 \\
\hline 47 & Ibiporã (PR) & 2008 & $5 \%$ & Lei ํo 2.236/2008 \\
\hline 48 & Nova Fátima (PR) & 2003 & $10 \%$ & Lei Estadual no 14.274/2003 \\
\hline 49 & Ponta Grossa (PR) & 2004 & $10 \%$ & Lei no $7.696 / 2004$ \\
\hline 50 & União da Vitória (PR) & 2003 & $10 \%$ & Lei Estadual no 14.274/2003 \\
\hline 51 & Poconé (MT) & 2008 & $20 \%^{3}$ & Lei no $1.476 / 2008$ \\
\hline 52 & Souza (PB) & 2004 & - & tei $n^{0}-1.982 / 2004$ e Lei $n^{0}$ 2.097/2008 (revoga lei anterior) \\
\hline 53 & Salvador (BA) & 2011 & $30 \%$ & Lei Complementar nº 54/2011 \\
\hline 54 & Cornélio Procópio (PR) & 2008 & $10 \%$ & Lei ำ 411/2008 \\
\hline 55 & São Paulo & 2013 & $20 \% \%^{2,4,5}$ & Lei no 15.939/2013 e Decreto no 54.949/2014 \\
\hline 56 & Cuiabá & 2014 & $20 \%{ }^{1}$ & Lei Municipal no 5.842, de 30 de julho de 2014 \\
\hline
\end{tabular}

Fonte: Adaptado de Ipea (2014)

Notas: ${ }^{1}$ Inclui indígenas.

${ }^{2}$ Reserva para mulheres negras.

${ }^{3}$ Inclui empresas terceirizadas.

${ }^{4}$ Inclui cargos em comissão.

${ }^{5}$ Inclui estágios.

${ }^{6}$ Inclui outros programas, como bolsas de estudo.

7 Inclui contratações temporárias.

Obs.: Atualizado até novembro de 2014. Localidades tachadas: já tiveram normas, mas agora estão suspensas/revogadas. 
